\title{
Immediate Species Responses to Catastrophic Natural Disturbances: Windthrow Effects on Density, Productivity, Nesting Stand Choice, and Fidelity in Northern Goshawks (Accipiter gentilis)
}

Author(s): Vincenzo Penteriani, Marie Mathiaut, Guy Boisson

Source: The Auk, 119(4):1132-1137. 2002.

Published By: The American Ornithologists' Union

DOI: http://dx.doi.org/10.1642/0004-8038(2002)119[1132:ISRTCN]2.0.CO;2

URL: http://www.bioone.org/doi/full/10.1642/0004-8038\%282002\%29119\%5B1132\%3AISRTCN

$\% 5 \mathrm{D} 2.0 . \mathrm{CO} \% 3 \mathrm{~B} 2$

BioOne (www.bioone.org) is a nonprofit, online aggregation of core research in the biological, ecological, and environmental sciences. BioOne provides a sustainable online platform for over 170 journals and books published by nonprofit societies, associations, museums, institutions, and presses.

Your use of this PDF, the BioOne Web site, and all posted and associated content indicates your acceptance of BioOne's Terms of Use, available at www.bioone.org/page/terms of use.

Usage of BioOne content is strictly limited to personal, educational, and non-commercial use. Commercial inquiries or rights and permissions requests should be directed to the individual publisher as copyright holder. 


\title{
Notes
}

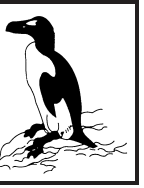

The Auk 119(4):1114-1120, 2002

\section{A Multifaceted Approach to the Characterization of an Intergeneric Hybrid Manakin (Pipridae) from Brazil}

\author{
Miguel Â. MARINI, ${ }^{1,3}$ ANd SHANnON J. HACKETT ${ }^{2,4}$ \\ ${ }^{1}$ Departamento de Biologia Geral, ICB, Universidade Federal de Minas Gerais, 30.161-970, \\ Belo Horizonte, MG, Brasil; and \\ ${ }^{2}$ Department of Zoology, Field Museum of Natural History, 1400 South Lake Shore Drive, \\ Chicago, Illinois 60605, USA
}

\begin{abstract}
A new intergeneric hybrid manakin is characterized using morphological characters and mitochondrial and nuclear DNA sequences. Many morphological traits suggest the bird is intermediate between Ilicura militaris and Chiroxiphia caudata. Sequences of the maternally inherited mitochondrial ND2 gene demonstrate the female parent to be Chiroxiphia caudata, and the nuclear beta-fibrinogen intron 5 sequences can not eliminate Chiroxiphia and Ilicura as parents. Therefore, DNA sequence data lead to the conclusion that Ilicura is the male parent of this unusual bird. This study is important because it highlights the significance of using multiple character systems in diagnosing unusual bird specimens.
\end{abstract}

Resumo.-Um novo híbrido intergenérico foi caracterizado utilizando caracteres morfológicos e seqüências de DNA nuclear e mitocondrial. Vários caracteres morfológicos sugerem que a ave é um intermediário entre Ilicura militaris e Chiroxiphia caudata. Seqüências do gene mitocondrial ND2 herdados via materna demonstram que a progenitora feminina foi uma Chiroxiphia caudata, e seqüências nucleares do intron 5 do beta-fibrinogênio não eliminaram Chiroxiphia e Ilicura como potenciais pais. Logo, os dados de seqüência de DNA levam à conclusão de que Ilicura é o progenitor masculino desta ave pouco comum. Este estudo é importante porque demonstra a significância de utilizar sistemas de múltiplos caracteres na diagnose de espécimes pouco comuns de aves.

On 25 March 1999, during a mist-netting program, an unusual male Ilicura militaris was captured and collected in a 200 ha forest fragment (elevation 1,100 m) at "Barreiro" watershed protection area (COPA-

\footnotetext{
${ }^{3}$ Present address: Departamento de Zoologia, IB, Universidade de Brasília (UnB) 70.910-900, Brasília, DF, Brasil. E-mail: marini@unb.br

${ }^{4}$ Address correspondence to this author. E-mail: shackett@fieldmuseum.org
}

SA) $\left(20^{\circ} 00^{\prime} \mathrm{S}, 44^{\circ} 00^{\prime} \mathrm{W}\right)$, near Belo Horizonte, Minas Gerais, Brazil. Morphological changes in that individual during years of field study led us to hypothesize that this individual was a hybrid. To determine its parentage, a comprehensive molecular and morphological approach was developed for assessing hybrid individuals. This study demonstrates how molecular sequence data can provide more detailed and conclusive information on such individuals when appropriate comparative material is available. In addition to morphological (plumage and morphometric data) analyses, nuclear (nDNA) and mitochondrial DNA (mtDNA) sequence data were gathered on this unusual manakin. The combination of those data allows us to show that this specimen is a hybrid, demonstrate that the parents were Ilicura militaris and Chiroxiphia caudata, and identify Chiroxiphia as the female parent. This represents the ninth documented intergeneric hybridization event within manakins (Parkes 1961, Sick 1979, Graves 1993, Stotz 1993), and the second record of a manakin hybrid from southeastern Brazil (Sick 1979, Pacheco and Parrini 1995), a highly fragmented region.

Materials and methods.-The specimen was prepared as a study skin and deposited at the Ornithology Laboratory of the Zoology Department, Universidade de Brasília, Brasília, Distrito Federal. Its carcass and liver were preserved in alcohol and buffer, respectively. Measurements of the hybrid and of adult and subadult males of four potential parents (Ilicura militaris, Chiroxiphia caudata, Antilophia galea$t a$, and Schiffornis virescens) were taken (sample sizes in Table 1) and plumage coloration and pattern assessed for comparison to the potential hybrid. Those four potential parents are or have been classified as manakins (Pipridae) and occur in the same forest as the potential hybrid. All measurements were made with metal calipers, including bill (nostril to tip of bill), tarsus, wing chord, long central tail feathers (rectrices number 1 ; the central pair), short tail feathers (rectrices number 2; the first feathers next to the central pair), and size of the reddish forecrown 
TABLE 1. Measurements of male Ilicura militaris, Chiroxiphia caudata, Antilophia galeata, Schiffornis virescens, and the presumed hybrid. Body weight is given in grams; measurements are in mm; values are $\bar{x} \pm$ SD (range; $n$ in parentheses).

\begin{tabular}{|c|c|c|c|c|c|}
\hline Variable & Ilicura & Chiroxiphia & Antilophia & Schiffornis & Hybrid \\
\hline Body weight & $\begin{array}{c}12.7 \pm 2.1 \\
(11-19.5 ; 23)\end{array}$ & $\begin{array}{c}23.0 \pm 2.4 \\
(17.5-29 ; 17)\end{array}$ & $\begin{array}{l}21.3 \pm 1.1 \\
(19-23 ; 17)\end{array}$ & $\begin{array}{c}25.0 \pm 2.0 \\
(22-27.7 ; 10)\end{array}$ & 18.5 \\
\hline Bill length & $\begin{array}{c}4.5 \pm 0.3 \\
(3.8-5.0 ; 31)\end{array}$ & $\begin{array}{c}6.3 \pm 0.4 \\
(5.1-7.1 ; 30)\end{array}$ & $\begin{array}{c}6.5 \pm 0.5 \\
(5.4-7.8 ; 17)\end{array}$ & $\begin{array}{c}8.0 \pm 0.3 \\
(7.5-8.4 ; 10)\end{array}$ & 5.6 \\
\hline Tarsus & $\begin{array}{c}19.2 \pm 1.0 \\
(17.6-22.4 ; 31)\end{array}$ & $\begin{array}{c}21.5 \pm 0.8 \\
(20.1-23.0 ; 30)\end{array}$ & $\begin{array}{c}21.0 \pm 1.1 \\
(19.2-23.5 ; 17)\end{array}$ & $\begin{array}{c}22.5 \pm 0.6 \\
(21.3-23.1 ; 10)\end{array}$ & 20.0 \\
\hline Wing & $\begin{array}{c}60.8 \pm 1.5 \\
(57.4-63.4 ; 31)\end{array}$ & $\begin{array}{c}73.4 \pm 3.1 \\
(67.1-78.9 ; 31)\end{array}$ & $\begin{array}{c}76.4 \pm 2.9 \\
(70.7-80.9 ; 17)\end{array}$ & $\begin{array}{c}77.1 \pm 1.9 \\
(73.3-79.8 ; 10)\end{array}$ & 69.5 \\
\hline $\begin{array}{l}\text { Central tail feathers } \\
\text { (retrices number } 1)\end{array}$ & $\begin{array}{c}63.9 \pm 2.3 \\
(61.1-66.2 ; 13)\end{array}$ & $\begin{array}{c}68.9 \pm 5.1 \\
(59.2-75.8 ; 18)\end{array}$ & $\begin{array}{c}72.9 \pm 2.7 \\
(67.8-79.4 ; 17)\end{array}$ & $\begin{array}{c}71.5 \pm 3.5 \\
(64.2-75.6 ; 10)\end{array}$ & 62.4 \\
\hline $\begin{array}{l}\text { Short tail feathers } \\
\text { (retrices number 2) }\end{array}$ & $\begin{array}{c}44.6 \pm 2.5 \\
(39.5-48.5 ; 13)\end{array}$ & $\begin{array}{c}54.0 \pm 3.5 \\
(44.5-60.3 ; 18)\end{array}$ & $\begin{array}{l}\text { Same length as cen- } \\
\text { tral retrices }\end{array}$ & $\begin{array}{l}\text { Same length as } \\
\text { central retrices }\end{array}$ & 47.6 \\
\hline Forecrown size & $\begin{array}{c}8.0 \pm 0.5 \\
(7.1-8.6 ; 11)\end{array}$ & $\begin{array}{c}26.4 \pm 1.6 \\
(22.9-29.5 ; 15)\end{array}$ & $\begin{array}{l}\text { No forecrown, but } \\
\text { red until middle of } \\
\text { back }\end{array}$ & No forecrown & 10.3 \\
\hline
\end{tabular}

(from bill to the center of the head). Antilophia and Schiffornis do not have elongated tail feathers; therefore only one standard tail measurement was taken. Body mass was recorded from live mist-netted individuals of all four possible parental species. Plumage assessments and measurements were taken from birds mist-netted at the study sites and from specimens (11 Ilicura and 15 Chiroxiphia) deposited at Department of Zoology, Universidade Federal de Minas Gerais, Belo Horizonte, Minas Gerais. Because body weights for Antilophia were unavailable from the Belo Horizonte study site, we used weights and measurements of birds mist-netted in 1994-1996 near Uberlândia, Minas Gerais $\left(18^{\circ} 45^{\prime} \mathrm{S}, 48^{\circ} 15^{\prime} \mathrm{W}\right)$.

DNA was isolated from the potential hybrid using a Puregene DNA isolation kit (Gentra Systems, Minneapolis, Minnesota) following the manufacturer's animal tissue protocol. Sequences of the four possible parental species were generated independently of this potential hybrid as part of a higher-level phylogenetic analysis of manakins and their relatives by S. J. Hackett (unpubl. data). The mitochondrial NADH dehydrogenase 2 (ND2) gene was amplified using the following primers ND2L-Met (L5215; TATCGGGCCCATACCCCGAATAT) and ND2H-Trp (H6313; CCTTTATTTAAGGCTTTGAAGGC). H and $\mathrm{L}$ refer to primers located on the heavy and light strands of the mitochondrial genome, respectively, and numbers refer to the $3^{\prime}$ base of the primer referenced to the complete mtDNA sequence of the chicken (Gallus gallus; Desjardins and Morais 1990). The nuclear $\beta$-fibrinogen gene (intron 5) was amplified with the following primers FIB5 (5'-CGCCATACAGAGTATACTGTGACAT-3') and FIB6 (5'GCCATCCTGGCGATTCTGAA-3'). Fragments were PCR amplified using standard conditions (denatur- ation at $94^{\circ} \mathrm{C}$, annealing at $54^{\circ} \mathrm{C}$, extension at $72^{\circ} \mathrm{C}$ ). PCR products were electrophoresed on a low-melt agarose gel to verify the presence of a single, clean PCR product of the correct size, extracted and digested with GELase Agarose Gel-Digesting Preparation "Fast Protocol" method (Epicentre Technologies, Madison, Wisconsin). Cleaned double-stranded amplifications were cycle sequenced using ABI Prism ${ }^{\circledR}$ BigDye Terminator Cycle Sequencing Ready Reaction Kits (Applied Biosystems Inc., Foster City, California). Cycle sequencing reactions were $\mathrm{Nh}_{4} \mathrm{OAc}$ precipitated with ethanol, dried, resuspended in a formamideEDTA solution, and run on an ABI 377 Automated DNA Sequencer. Sequences were obtained from both strands of DNA, checked using the program SEQUENCHER 3.1.1 (Gene Codes, 1995), and submitted to GenBank (accession numbers AY136615AY136621). Sequences and chromatograms (results of the automated sequencing) were then compared to those from the four potential parental species.

Results and discussion.-When the bird was first captured on 31 May 1997, it had female-like green plumage. It was identified as a "green" unsexed Chiroxiphia caudata due to the strong resemblance with green individuals of that species, weighed $15.5 \mathrm{~g}$, and was metal and color banded. When the bird was recaptured in March 1999, it had an almost full adult male Ilicura plumage, but with several greenish feathers.

This individual is large compared to adult male Ilicura (Table 1, Figs. 1 and 2). Its rump and upper tail-coverts are gray at the base, green in the middle, and black at the tip instead of white at the base and scarlet at the tip, as is characteristic of adult male Ilicura (Fig. 1B). This feather coloration, however, may 


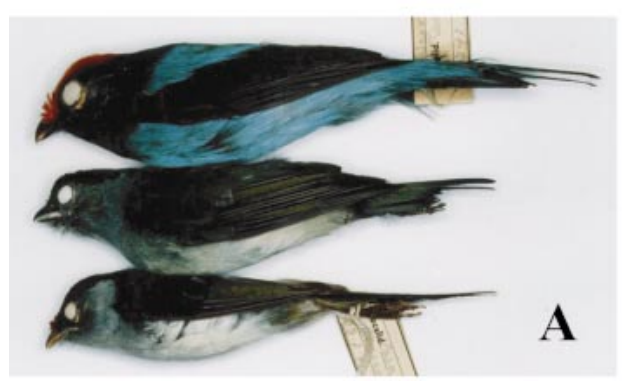

Chiroxiphia
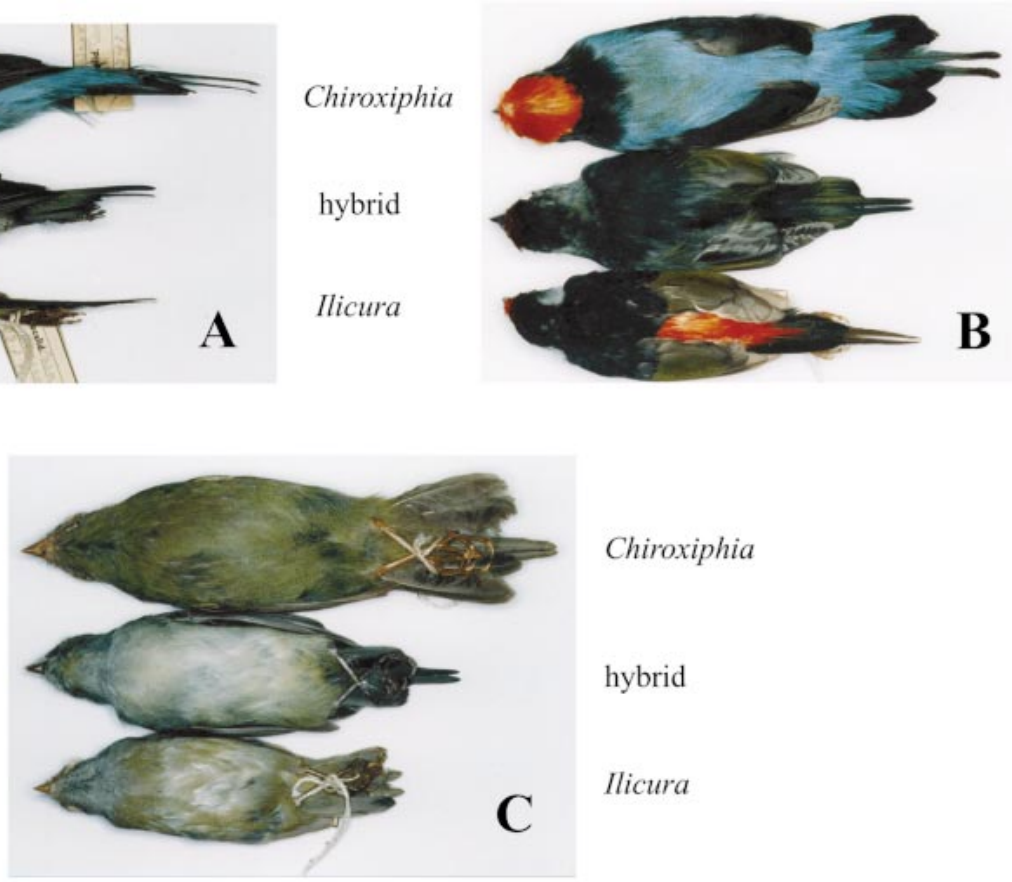

Chiroxiphia

hybrid

\section{Ilicura}

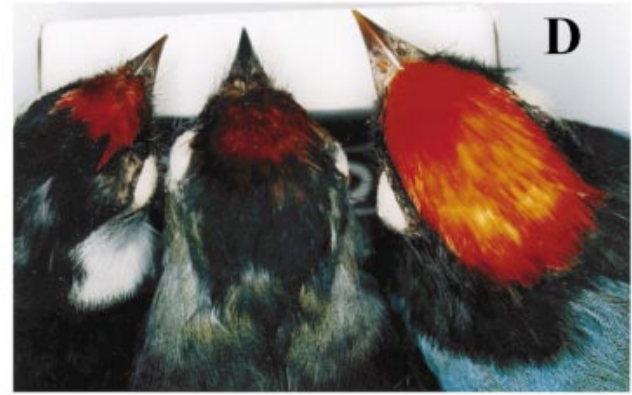

Ilicura hybrid

Chiroxiphia

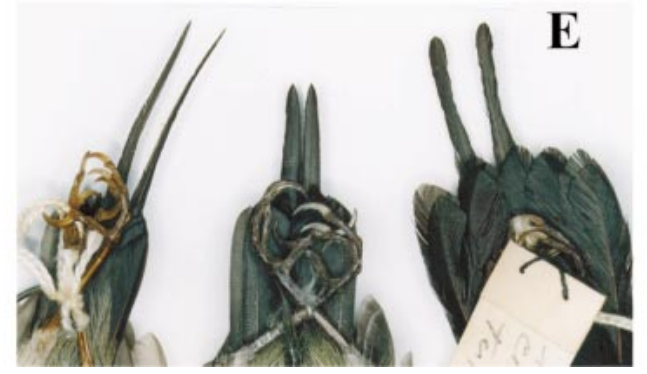

FIG. 1. Pictures of the hybrid individual and the proposed parental species (Ilicura militaris and Chiroxiphia caudata). 


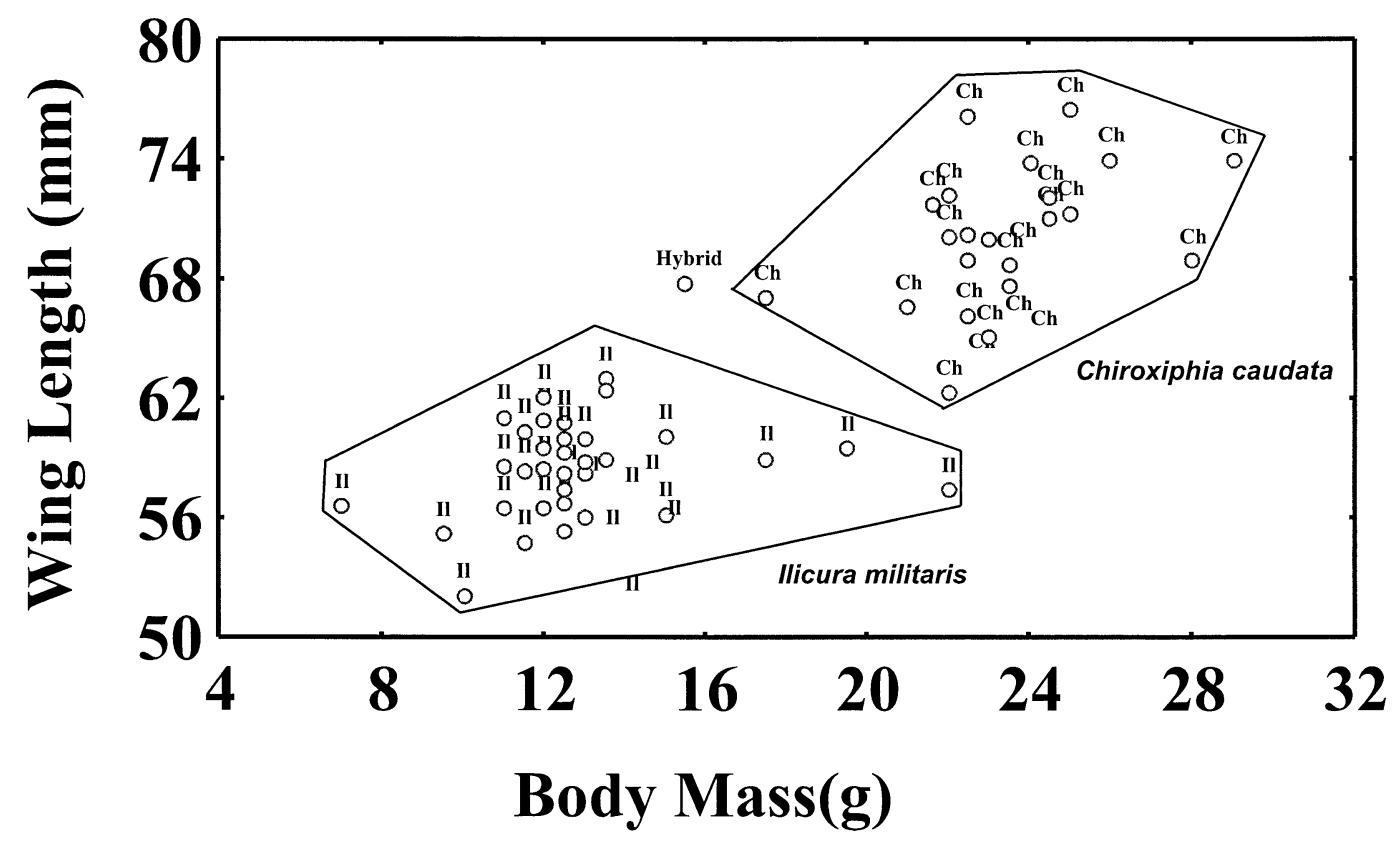

FIG. 2. Bivariate plot of wing length (millimeters) and body mass (grams) of Ilicura militaris and Chiroxiphia caudata, and the presumed I. militaris $\times$ C. caudata hybrid.

not be specific to the hybrid because immature Ilicura males have been captured with few scarlet feathers on the rump but with a full crimson forecrown (M. Anciães pers. comm.). The back (Fig. 1B), with its mostly dark coloration, resembles a subadult male Antilophia rather than either an Ilicura (which has red on the back) or a Chiroxiphia (which has a blue back).

The underparts (Fig. 1C) are a mixture of green, gray, and white feathers, with the upper breast and throat more grayish and the belly whitish, resembling Ilicura and not Chiroxiphia or Antilophia, which have green underparts when they are immature.

The forecrown (Fig. 1D) is reddish and intermediate in color between Ilicura and Chiroxiphia adult males. These feathers are short, similar to Ilicura and Chiroxiphia, and very different from the erected forecrown characteristic of even Antilophia females and males with predefinitive plumage. Both sexes of Schiffornis have only green plumage.

The purple tarsus is darker than in Ilicura, resembling Chiroxiphia or Antilophia. The skull was half pneumatized and testes were small $(1 \times 1 \mathrm{~mm})$. However, from the capture-recapture dates, we estimate that the bird was a least 2-2.5 years old, because reproduction occurs mostly between October and December (based on Chiroxiphia nests and Ilicura brood patches in the region). Also, many manakins have delayed plumage maturation with the acquisition of the full adult plumage by the end of the third year of life (e.g. Chiroxiphia; Foster 1987). Little is known about the subadult plumage of male Ilicura and whether it also has delayed plumage maturation.

Two manakins (C. caudata and A. galeata) occur syntopically with Ilicura in forest fragments of the region. Chiroxiphia has a geographical distribution that is similar to, but more extensive than Ilicura, whereas Antilophia occurs mostly in central Brazil, an almost allopatric distribution to the other two species (Sick 1997). The study site where the hybrid was captured is close to the edge of the geographical distribution of the three species and in a place where their ranges just come together. This geographic scenario may promote hybridization as discussed by Rohwer (1994) because individuals at the edges of their ranges may have difficulty finding mates of the same species (Short 1969, Rohwer 1972). Schiffornis virescens also occurs in these forests and was included in the analyses, even though it is no longer considered a manakin by Prum (1990a, b, 1992, 1994).

In diagnosing the putative hybrid using morphological characters, we follow Graves (1990), assuming that mensural characters are additive and polygenic, with the hybrid's morphology not exceeding that of the parental species (Falconer 1989). The expression of plumage characters depends on the number of encoding genes and their interaction, and hybrids may resemble either parent or a mosaic of the parental species (Hutt 1949 and Buckley 1982, cited in Graves 1990). With these assumptions, Chiroxiphia 
arises as the most probable putative parent (with $\mathrm{Ili}$ cura) for the following reasons:

1. Immature predefinitive plumage is consistent with Chiroxiphia as a hypothesized parent species. At first capture, the hybrid was identified as a green, unsexed Chiroxiphia due to the close resemblance in plumage, and not as a green unsexed Antilophia, Ilicura, or Schiffornis. The lack of the erected feathers in the forecrown, characteristic even in Antilophia females and males with predefinitive plumage, argues strongly against Antilophia as a putative parent. Body color argues against Schiffornis, which has a darker green plumage than the other three species.

2. The deep crimson forecrown was intermediate in color and size between Ilicura and Chiroxiphia. It was more extensive (Table 1) and brighter (with a more orange-like color) in the hybrid than in Ilicura, but much smaller than in Chiroxiphia. Because Schiffornis does not have a colored forecrown, the size of the forecrown could not be bigger than in Ilicura.

3. The hybrid's iris color was intermediate between Ilicura's and Chiroxiphia's. Its iris color was reddish brown, very different from the orange iris of Ilicura, and the dark brown iris of Chiroxiphia, but resembling the iris of Antilophia.

4. Head shape of the hybrid resembled Chiroxiphia's or Schiffornis' round head instead of the more slender head of Ilicura or Antilophia. However, no measurement was taken.

5. Body mass was intermediate between Ilicura's and that of the other three taxa. It was, however, nearer to the mean mass between Ilicura and Schiffornis (1.9\% smaller) and Ilicura and Chiroxiphia (3.5\% larger) than to the mean between Ilicura and Antilophia (8.1\% larger) (Fig. 2, Table 1).

6 . The modified central tail feathers (rectrices number 1) were intermediate in shape between the round-shaped tail feathers of Chiroxiphia and the narrow, pointed tail feathers of Ilicura (Fig. 1E). Antilophia and Schiffornis have long unmodified tail feathers, very different from the hybrid, Ilicura, or Chiroxiphia.

7. The length of the short tail feathers (rectrices number 2) of the hybrid is closer to the mean between Ilicura and Chiroxiphia than to the mean between Ilicura and Antilophia, or Ilicura and Schiffornis (Table 1). The central tail feather length (rectrices number 1) is the only measurement smaller in the hybrid than in Ilicura, Chiroxiphia, Antilophia, and Schiffornis. Antilophia and Schiffornis rectrices are longer than those of Ilicura or Chiroxiphia (outside the characteristic two central long feathers). Thus, if Antilophia or Schiffornis were one of the parents, one would expect much longer external rectrices in the hybrid than were found (Table 1). Tarsus, bill, and wing length are always intermediate and are close to means between Ilicura and any of the other three taxa.

8. A bivariate plot between wing length and body mass (Fig. 2) shows that the hybrid falls between Ilicura and Chiroxiphia as has been shown for other hybrids (Graves 1990, 1993, 1997).

One possible parental combination suggested by the morphological analyses was $I$. militaris and A. galeata. Although Antilophia is at the limits of its geographical distribution, which is consistent with earlier arguments we make supporting possible hybridization, the species is very rare at that locality and therefore a less likely candidate. Also, one could hypothesize that a potential constraint of a mating between Antilophia and Chiroxiphia could exist, because Antilophia defends resource territories (Marini 1992) and does not show lekking behavior (Marini and Cavalcanti 1992), unlike Ilicura (Snow and Snow 1985) or C. caudata (Foster 1981). However, despite differences in their mating systems, Antilophia has been reported to hybridize with the lekking C. caudata in southern Minas Gerais and São Paulo states (Sick 1979, Pacheco and Parrini 1995).

The other parental combination-between Ilicura and Schiffornis-is the least probable due to the arguments made above and criteria developed by Rohwer (1994). If this were the pairing, then the hybrid plumage resembles only one of the parents (Ilicura), with few potential intermediate characters.

Sequence data can provide additional support for determining paternity of a hybrid individual. Mitochondrial DNA (mtDNA) is maternally inherited in vertebrates (Lansman et al. 1983), and provides data relevant to the maternal parent. Nuclear sequences should contain evidence of alleles from both parents. Assuming there are significant molecular differences between the possible parents, then the combination of these data could provide definitive evidence regarding paternity. We obtained $665 \mathrm{bp}$ of mtDNA sequence data from the potential hybrid and the four possible parental species. There were only two nucleotide differences $(0.3 \%)$ between sequences of the hybrid and C. caudata (Field Museum \#395458 from Brazil, São Paulo, Boraceia). That is well within the range of variation of a single population of birds and provides strong evidence that C. caudata was the female parent of this individual. Uncorrected mtDNA distances of 
Chiroxiphia to the other possible parents are quite large (14\% to Ilicura, $7.7 \%$ to Antilophia, and $21.6 \%$ to Schiffornis). Thus, none of those species is genetically similar to Chiroxiphia or the hybrid individual. The molecular data agree with the morphologic data that Schiffornis is very distantly related to other manakins (as has been suggested previously by the work of Prum 1990a, b, 1992, 1994).

With the female parent identified by the mtDNA data, the male parent may be inferred by examining the nuclear sequence data. The nuclear DNA evolves slower than mtDNA (Prychitko and Moore 1997), and genetic distances between species are not as great. There are, however, diagnostic nucleotide positions in the $\beta$-fibrinogen intron 5 sequences that can rule out two of the possible parental taxa. The aligned intron data set was $563 \mathrm{bp}$ long. There are 35 positions that positively rule out $S$. virescens as a potential parent and five that rule out A. galeata. At none of these positions does the hybrid show any evidence of sharing this nucleotide (e.g. two bases seen in the chromatogram) with these species. In contrast, there are no positions that rule out $C$. caudata or I. militaris. In fact, of the 18 intron positions where Chiroxiphia differs in sequence from Ilicura, the hybrid individual shows evidence of both parental nucleotides (two bases seen in the chromatograms) at 15 of the positions. This level of heterozygosity is consistent with this individual being a first generation (or F1) hybrid. Interestingly, the hybrid sequence does not show evidence of both nucleotides at all 18 positions. We note that we did not sample the actual parental individuals for this hybrid, and so we attribute this to natural intraspecific variation within each of the hybrid parental species, common in birds (Congdon et al. 2000). Thus, the combination of mitochondrial and nuclear sequence data support Chiroxiphia as the female parent and Ilicura as the male parent of this hybrid individual.

The finding of a Ilicura $\times$ Chiroxiphia hybrid coupled with the large genetic distances between the two species reinforces previous discussions that manakin hybrids can occur between species that have been evolving independently for millions of years (Parkes 1961, Stotz 1993, Rohwer 1994). This argument proposes that some kind of isolating mechanism, probably behavioral, keeps closely related species apart; these mechanisms may break down between distantly related species (Parkes 1961, Gill 1998). We note that geography should also be considered in such discussions. Closely related taxa often have allopatric distributions and are therefore unlikely to come into close contact and hybridize.

Why would a female $C$. caudata mate with a male I. militaris? The female $C$. caudata might have been attracted to the arena of a displaying male I. militaris. If there is a female-biased sex ratio in C. caudata due to a random demographic effect in a forest fragment, then the $C$. caudata female may mate with the Ilicura male. However, mist-net captures over a five-year period (1995-2000) reveal a sex ratio close to $1: 1$, if most green individuals are considered females (M. Â. Marini unpubl. data). Another explanation could be forced copulation by an adult or mostly likely a subadult male I. militaris. Because manakins have delayed plumage maturation, subadult males are less likely to mate at displaying leks and could increase their reproductive success by intercepting females. The interception of the female of the wrong species would be more likely by inexperienced individuals.

In conclusion, we support the addition of molecular sequence data to the examination of unusual individuals. Recent analyses of plumage and morphometrics of hybrids have increased the rigor of their identification. Molecular data are a powerful addition because they can not only confirm a hybrid individual and identify parental species, they can also resolve the specific direction of the hybridization event by identifying the species of both the male and female parent.

Acknowledgments.-This study was conducted while M.Â.M. held a Researcher Fellowship from $\mathrm{CNPq}$, and was a result of research funded by $\mathrm{CNPq}$ and FAPEMIG. IBAMA provided banding and collecting permits; COPASA allowed study on their properties. We thank M. Vasconcelos for preparing the skin and preserving the carcass in alcohol. Molecular sequencing was done in the Pritzker Laboratory for Molecular Systematics and Evolution, operated with support from the Pritzker Foundation. We thank J. Hunt for his assistance in the lab. M. Anciães, J. Bates, K. Bostwick, P. Cordeiro, G. Graves, R. Prum, J. M. C. Silva, and an anonymous reviewer improved the manuscript with their comments.

\section{Literature Cited}

Congdon, B. C., J. F. Piatt, K. Martin, and V. L. FRIESEN. 2000. Mechanisms of population differ- 
entiation in Marbled Murrelets: Historical versus contemporary processes. Evolution 54:974986.

Desjardins, P., AND R. Morais. 1990. Sequence and gene organization of the chicken mitochondrial genome. Journal of Molecular Biology 212:599_ 634.

FAlCONER, D. S. 1989. Introduction to Quantitative Genetics, 3rd ed. Longman Scientific Technical, Essex, United Kingdom.

Foster, M. S. 1981. Cooperative behavior and social organization of the Swallow-tailed Manakin (Chiroxiphia caudata). Behavioral Ecology and Sociobiology 9:167-177.

Foster, M. S. 1987. Delayed maturation, neoteny, and social system differences in two manakins of the genus Chiroxiphia. Evolution 41:547-558.

GILL, F. B. 1998. Hybridization in birds. Auk 115:282283.

Graves, G. R. 1990. Systematics of the "Greenthroated Sunangels" (Aves: Trochilidae): Valid taxa or hybrids? Proceedings of the Biological Society of Washington 103:6-25.

GrAvES, G. R. 1993. A new hybrid manakin (Dixiphia pipra $\times$ Pipra filicauda) (Aves: Pipridae) from the Andean foothills of eastern Ecuador. Proceedings of the Biological Society of Washington 106: 436-441.

GRAVES, G. R. 1997. Diagnoses of hybrid hummingbirds (Aves: Trochilidae). 4. Hybrid origin of $\mathrm{Ca}$ lothorax decoratus Gould. Proceedings of the Biological Society of Washington 110:320-325.

Lansman, R. A., J. C. Avise, and M. D. Huetel. 1983. Critical experimental test of the possibility of "paternal leakage" of mitochondrial DNA. Proceedings of the National Academy of Sciences USA 80:1969-1971.

MARINI, M. Â. 1992. Notes on the breeding and reproductive biology of the Helmeted Manakin. Wilson Bulletin 104:168-173.

Marini, M. Â., AND R. B. CAVAlCANTI. 1992. Mating system of the Helmeted Manakin (Antilophia galeata) in central Brazil. Auk 109:911-913.

PACHeCO, J. F., AND R. PARRINI. 1995. O "rei-dos-tangarás" (Chiroxiphia caudata $\times$ Antilophia galeata) no sul de Minas Gerais. Atualidades Ornitológicas 66(Julho):14.
PARKES, K. C. 1961. Intergeneric hybrids in the family Pipridae. Condor 63:345-350.

Prum, R. O. 1990a. Phylogenetic analysis of the evolution of display behavior in the Neotropical manakins (Aves: Pipridae). Ethology 84:202231.

Prum, R. O. 1990b. A test of the monophyly of the manakins (Pipridae) and of the cotingas (Cotingidae) based on morphology. Occasional Papers of the Museum of Zoology, University of Michigan, no. 723.

PRUM, R. O. 1992. Syringeal morphology, phylogeny, and evolution of the Neotropical manakins (Aves: Pipridae). American Museum of Natural History Novitates, no. 3043.

PRUM, R. O. 1994. Phylogenetic analysis of the evolution of alternative social behavior in the manakins (Aves: Pipridae). Evolution 48:1657-1675.

PrychitKo, T. M., AND W. S. Moore. 1997. The utility of DNA sequences of an intron from the $\beta$-fibrinogen gene in phylogenetic analysis of woodpeckers (Aves: Picidae). Molecular Phylogenetics and Evolution 8:193-204.

ROHWER, S. A. 1972. A multivariate assessment of interbreeding between the meadowlarks, Sturnella. Systematic Zoology 21:313-338.

RoHwer, S. A. 1994. Two new hybrid Dendroica warblers and new methodology for inferring parental species. Auk 111:441-449.

SHORT, L. 1969. Taxonomic aspects of avian hybridization. Auk 86:84-105.

SICK, H. 1979. Notes on some Brazilian birds. Bulletin of the British Ornithologists' Club 99:115120.

SICK, H., ED.1997. Ornitologia Brasileira. Nova Fronteira, Rio de Janeiro, Brazil.

SNOW, B. K., AND D. W. SNOW. 1985. Display and related behavior of male Pin-tailed Manakins. Wilson Bulletin 97:273-282.

Stotz, D. F. 1993. A hybrid manakin (Pipra) from Roraima, Brazil, and a phylogenetic perspective on hybridization in the Pipridae. Wilson Bulletin 105:348-351.

Received 7 September 2001, accepted 8 June 2002. Associate Editor: F. Sheldon 


\title{
Daily Energy Expenditures of Free-Ranging Common Loon (Gavia immer) Chicks
}

\author{
François Fournier, ${ }^{1,4}$ William H. Karasov, ${ }^{1}$ Michael W. Meyer, ${ }^{2}$ and Kevin P. Kenow ${ }^{3}$ \\ ${ }^{1}$ Department of Wildlife Ecology, 226 Russell Labs, University of Wisconsin-Madison, \\ Madison, Wisconsin 53706, USA; \\ ${ }^{2}$ Wisconsin Department of Natural Resources, 107 Sutliff Avenue, Rhinelander, Wisconsin 54501, USA; and \\ ${ }^{3}$ Upper Midwest Environmental Sciences Center, U.S. Geological Survey, Biological Resources Division, \\ 2630 Fanta Reed Road, La Crosse, Wisconsin 54603, USA
}

\begin{abstract}
We measured the daily energy expenditure of free-living Common Loon (Gavia immer) chicks using doubly labeled water (DLW). Average body mass of chicks during the DLW measures were $425,1,052$, and $1,963 \mathrm{~g}$ for 10 day-old $(n=5), 21$ dayold $(n=6)$, and 35 day-old $(n=6)$ chicks, respectively, and their mean daily energy expenditures (DEE) were $686 \mathrm{~kJ} \mathrm{day}^{-1}, 768 \mathrm{~kJ} \mathrm{day}^{-1}$, and 1,935 kJ day $^{-1}$, respectively. Variation in DEE was not due solely to variation in body mass, but age was also a significant factor independent of body mass. Energy deposited in new tissue was calculated from age-dependent tissue energy contents and measured gains in body mass, which were 51,54, and $33 \mathrm{~g} \mathrm{day}^{-1}$ from the youngest to oldest chicks. Metabolizable energy (the sum of DEE and tissue energy) was used to estimate feeding rates of loon chicks and their exposure to mercury in the fish they consume. We calculated that loon chicks in Wisconsin consumed between 162 and $383 \mathrm{~g}$ wet mass of fish per day (depending on age), corresponding to intakes of mercury of 16-192 $\mu \mathrm{g} \mathrm{day}^{-1}$.
\end{abstract}

RÉSUMÉ.-Nous avons mesuré les dépenses quotidiennes en énergie chez des jeunes Plongeons huards en milieu naturel à l'aide de l'eau doublement marquée (DLW). La masse corporelle moyenne des jeunes pendant les mesures de DLW étaient de $425,1,052$, et $1,963 \mathrm{~g}$ pour les jeunes âgés de 10 jours $(n=5), 21$ jours $(n=6)$, et 35 jours $(n=6)$, respectivement, et leurs dépenses moyennes en énergie (DEE) étaient de 686,768 , et $1,935 \mathrm{~kJ} \mathrm{jour}^{-1}$, respectivement. La variation en DEE n'était pas seulement attribuable à la variation en masse corporelle puisque l'âge était aussi un facteur significatif indépendamment de la masse corporelle. L'énergie déposée sous forme de nouveaux tissus a été calculée à partir du contenu énergétique des tissus selon l'âge et les gains en masse corporelle, qui eux étaient de 51, 54, et $33 \mathrm{~g} \mathrm{jour}^{-1}$ des plus jeunes aux plus vieux. L'énergie métabolisable, soit la somme des DEE et de l'énergie contenue dans les tissus, a été utilisée pour déterminer le taux de consommation de nourriture

\footnotetext{
${ }^{4}$ Present address: Département de Biologie, Université de Moncton, Moncton, New Brunswick E1A 3E9, Canada. E-mail: fournif@umoncton.ca
}

par les jeunes Plongeons huards et pour déterminer leur exposition au mercure contenu dans les poissons consommés. Nous avons calculé que les jeunes Plongeons huards, au Wisconsin, consommaient entre 162-383 g masse fraîche de poisson chaque jour (selon l'âge), et cela correspondait à une ingestion de mercure de 16-192 $\mu \mathrm{g}$ jour $^{-1}$.

The daily energy requirements of growing chicks have mostly been used to assess the energetic burden that parents face when having to supply their offspring with an appropriate amount of food resources (Drent and Daan 1980). That information betters the understanding of how a parent's ability to supply food to its offspring sets an energy limitation on its own reproductive success. However, knowledge of the energy requirements of free-living organisms can be used to answer more applied questions as well. Knowledge of energy requirements of free-living individuals can be used to assess their exposure to toxicants in food. Wildlife toxicologists can predict feeding rate, and hence toxicant intake, from knowledge of the metabolizable energy budget and the metabolizable energy per gram of food (Karasov and Meyer 2000).

This study of the metabolizable energy budget of Common Loons (Gavia immer) was part of a larger project focused on the effects of mercury on Common Loons (Meyer et al. 1998). The overarching goal was to develop a bioenergetic model for the bioaccumulation of mercury in loon chicks, which could be matched with other data on the effects of mercury exposure. Reliable data was needed on the energetics of loon chicks during their postnatal development. Unfortunately, no information is currently available on the energetics of free-living loons, nor do we know of any measurements of resting metabolism in captivity. Whereas the energy expenditure of adult birds often can be accurately predicted on the basis of body mass (Nagy et al. 1999), energetics during postnatal growth can be complicated by additional costs of biosynthesis and changes in thermoregulatory costs as the insulative layer of feathers develops. An allometric equation for the daily metabolizable energy of chicks has been proposed (Weathers 1996), but it is based on 30 mostly nidicolous species that develop under quite different ecological conditions 
than loons. We therefore measured the daily energy expenditure in free-living loon chicks during the developmental period using doubly labeled water (DLW; Visser and Schekkerman 1999) to collect baseline data on their energetics for use in our toxicokinetic modeling.

The developmental period for loon chicks lasts approximately 10-12 weeks, with chicks reaching asymptotic mass in $\sim 70$ days posthatch (Barr 1996). We measured the daily energy expenditure of chicks slightly before (day 10) and during the linear portion of their postnatal developmental period (days 21 and 35; F. Fournier et al. unpubl. data).

Methods.-This study was carried out on freshwater lakes in northern Wisconsin during the summer of 1998. Lakes were visited on a regular basis as soon as loons were present, and those efforts were part of an ongoing monitoring program on the effects of $\mathrm{Hg}$ on the reproductive success of loons. Once we located nests, they were checked every second day for the presence of eggs, and the fate of the eggs was monitored until the chicks hatched. Exact hatch date was determined for all chicks included in this study and therefore their ages were certain. Upon hatch the survival of chicks was assessed throughout the summer (eight weeks posthatch).

On days that energy expenditure was measured, chicks were captured (as authorized in federal scientific collecting permit number PRT-801326 and Wisconsin DNR scientific collectors permit number SCP-NC-32-97) on their nesting lake using a nightlighting technique (Evers 2001). Briefly, spotlights were used to search the lake and recorded calls were used to attract loons to the boat. We netted the chicks using a large landing net, placed them in a holding container, and transported them to shore.

Daily energy expenditures of chicks aged 10, 21, and 35 days was measured. Upon capture, each bird was weighed to the nearest $0.5 \mathrm{~g}$ with an electronic field balance and tagged with an aluminum web tag for identification, and a background blood sample was taken from the medial metatarsal vein $(\sim 1 \mathrm{~mL})$. A predetermined mass of DLW solution was injected (0.56 $\mathrm{g} \mathrm{DLW} \mathrm{kg}^{-1}$ body mass; $0.18 \mathrm{~g} \mathrm{99 \%}{ }^{2} \mathrm{HHO} \mathrm{kg}{ }^{-1}$

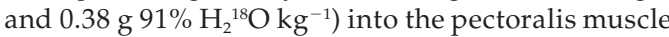
using a Hamilton precision glass syringe. The exact amount of DLW solution injected was determined by weighing the syringe on a portable field balance before and after injection $( \pm 0.01 \mathrm{~g})$. Isotopes were allowed $2 \mathrm{~h}$ to equilibrate with body fluids, after which time a $1 \mathrm{~mL}$ blood sample was collected to determine initial isotope enrichments. Chicks were then returned to the lake; the parents were attracted to the boat using taped chick calls, and the chicks were released next to the adult bird to avoid separation, therefore reducing the risk of chick mortality. Chicks were subsequently recaptured either 48 (10 day-old chicks) or $72 \mathrm{~h}$ (21 and 35 day-old chicks) after injection and brought to shore and weighed. A final blood sample was collected to determine the final enrichment of both isotopes, and chicks were returned to the lake and released with a parent. Each blood sample was immediately centrifuged after collection and the plasma was drawn off, stored in glass vacutainers, and refrigerated for later analyses.

Eight chicks were dosed at each sampling time (10, 21 , and 35 days posthatch) and recaptured for subsequent blood samples. We could not use some of the samples during the analyses because of small blood volumes. Final sample sizes used in statistical analyses were five for the 10 day-olds, six for the 21 dayolds, and six for the 35 day-olds.

All plasma samples were analyzed by isotope-ratio mass spectrometry at the University of Wisconsin-Madison Department of Nutritional Sciences. Samples were run in duplicate, and additional samples were run if the coefficient of variation was $>5 \%$. Average coefficients of variation for intial and final samples were $4.3 \%$ for ${ }^{18} \mathrm{O}$ and $4.4 \%$ for deuterium. Some samples were lost because of low volumes. Total body water volumes were determined from the initial dilution space of ${ }^{18} \mathrm{O}$ (Nagy 1980). Total body water is influenced by changes in body size, and because the chicks were growing in between sampling periods, it was assumed that the change was linear (Nagy 1980), and the mean mass of individuals from both capture intervals in our calculations was used. Rate of $\mathrm{CO}_{2}$ production was calculated from the declines in specific activities of deuterium and ${ }^{18} \mathrm{O}$ over time using Nagy's (1980) equation that assumes a linear change in the body water pool. Rates of $\mathrm{CO}_{2}$ production were converted to units of kilojoules per day assuming an energetic conversion factor of $27.33 \mathrm{~J}$ $\mathrm{mL}^{-1} \mathrm{CO}_{2}$ for a fish diet (Gessaman and Nagy 1988).

Amount of energy deposited in new tissues over the 48 or $72 \mathrm{~h}$ sampling period was determined by multiplying the gain in body mass by the caloric content of new tissues. Age-dependent energy content of tissues was estimated (4.13-7.18 $\mathrm{kJ} \mathrm{g}^{-1}$ wet mass) from a regression equation for several species of birds (equation 13.10 in Weathers 1996).

The statistical analysis procedure was selected on the basis of the consideration that body size (measured here as mass) is a major determinant of wholeanimal metabolism, but age might also have massindependent effects. Consequently, daily energy expenditure and metabolizable energy (which includes energy deposited in tissue) were analyzed by one-way analysis of variance (ANOVA) with post hoc Tukey comparisons of means by age (10, 21, and 35 days) and by analysis of covariance (ANCOVA) with age as a factor and body mass as a covariate. In the ANCOVA, metabolism and body mass were first log transformed, and interactions between age and logmass were removed from the ANCOVA model if not significant (i.e. if $P>0.05$ ). Means are expressed \pm SE. 
TABLE 1. Summary of daily energy expenditures (DEE), measured with doubly labeled water, energy deposited in new tissues $\left(\mathrm{E}_{\mathrm{tis}}\right)$, and metabolizable energy $(\mathrm{ME})$ in free-ranging Common Loon chicks.

\begin{tabular}{|c|c|c|c|c|c|c|c|}
\hline $\begin{array}{l}\text { Age } \\
\text { (days) }\end{array}$ & $\begin{array}{c}\text { Sampling } \\
\text { interval } \\
\text { (days) }\end{array}$ & $\begin{array}{l}\text { Initial mass } \\
(\mathrm{g})\end{array}$ & $\begin{array}{l}\text { Final mass } \\
(\mathrm{g})\end{array}$ & $\begin{array}{c}\text { Mass change } \\
(\mathrm{g})\end{array}$ & $\begin{array}{c}\mathrm{DEE} \\
\left(\mathrm{kJ} \mathrm{d}^{-1}\right)\end{array}$ & $\begin{array}{c}\mathrm{E}_{\mathrm{tis}^{\mathrm{a}}} \\
\left(\mathrm{kJ} \mathrm{d}^{-1}\right)\end{array}$ & $\begin{array}{c}\mathrm{ME}^{\mathrm{b}} \\
\left(\mathrm{kJ} \mathrm{d}^{-1}\right)\end{array}$ \\
\hline 10 & 2 & 373.5 & 471.3 & 97.8 & 736 & 206 & 942 \\
\hline 10 & 2 & 341.5 & 423.2 & 81.7 & 613 & 169 & 782 \\
\hline 10 & 2 & 358.0 & 456.0 & 98.0 & 589 & 205 & 794 \\
\hline 10 & 2 & 378.5 & 490.0 & 111.5 & 726 & 236 & 962 \\
\hline 10 & 2 & 419.5 & 535.5 & 116.0 & 768 & 249 & 1017 \\
\hline 21 & 3 & 1093.5 & 1162.5 & 69.0 & 899 & 120 & 1019 \\
\hline 21 & 3 & 1006.0 & 1202.5 & 196.5 & 592 & 346 & 938 \\
\hline 21 & 3 & 926.0 & 1142.5 & 216.5 & 604 & 374 & 978 \\
\hline 21 & 3 & 850.0 & 1050.5 & 200.5 & 775 & 338 & 1113 \\
\hline 21 & 3 & 803.5 & 956.5 & 153.0 & 741 & 251 & 992 \\
\hline 21 & 3 & 1145.5 & 1285.0 & 139.5 & 995 & 251 & 1246 \\
\hline 35 & 3 & 1722.0 & 1770.0 & 48.0 & 1527 & 98 & 1625 \\
\hline 35 & 3 & 1360.5 & 1423.5 & 63.0 & 1533 & 118 & 1651 \\
\hline 35 & 3 & 1867.5 & 2101.5 & 234.0 & 2347 & 515 & 2862 \\
\hline 35 & 3 & 2012.0 & 2041.5 & 29.5 & 1950 & 64 & 2014 \\
\hline 35 & 3 & 2400.0 & 2498.5 & 98.5 & 2122 & 236 & 2358 \\
\hline 35 & 3 & 2120.5 & 2235.5 & 115.0 & 2130 & 260 & 2390 \\
\hline
\end{tabular}

a Energy deposited in new tissues is the product of daily mass gain and caloric content of tissues.

${ }^{b}$ Metabolizable energy is the sum of daily energy expenditures and energy deposited in new tissues.

Results.-Mean body mass increased significantly from age $10(425 \pm 103 \mathrm{~g})$ to $21(1,052 \pm 94)$ to 35 days $(1,953 \pm 94 \mathrm{~g})(F=63, \mathrm{df}=2$ and $14, P<0.001$; all means significantly different from each other). Mean daily energy expenditure also increased significantly with age $(F=54.5, \mathrm{df}=2$ and $14, P<$ $0.0001)$, but means at 10 and 21 days did not differ from one another (respectively, $686 \pm 36$ vs. $768 \pm$

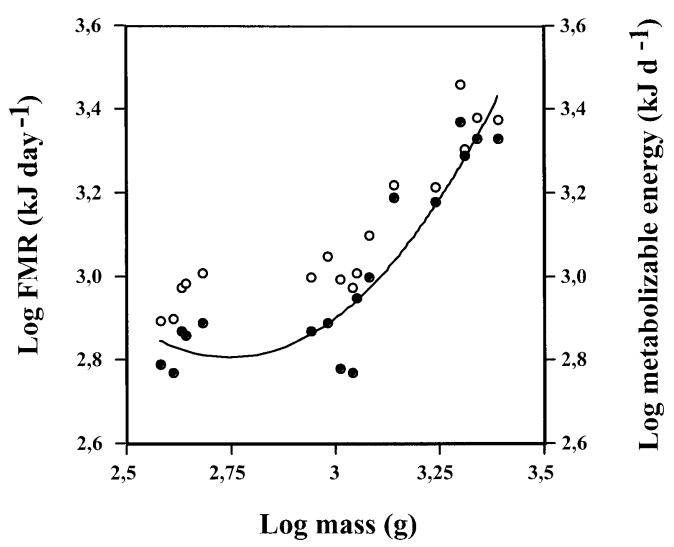

FIG. 1. Relationship between $\log _{10}$ daily energy expenditures (kilojoules per day) and $\log _{10}$ body mass (grams) (filled circles), and $\log _{10}$ metabolizable energy (kilojoules per day) and $\log _{10}$ body mass (grams) (open circles) in free-ranging Common Loon chicks. The line through the filled circles represents the polynomial regression between mass and energy expenditure (see text for details). $\left.65 \mathrm{~kJ} \mathrm{day}^{-1}, P>0.8\right)$ though both were significantly lower than expenditure at 35 days $(1935 \pm 138 \mathrm{~kJ}$ day $^{-1}$ ). Metabolizable energy, which includes joules deposited in new tissue based on observed mass increases (Table 1$)$, increased significantly with age $(F$ $=29.8, \mathrm{df}=2$ and $14, P<0.0001)$, but means at 10 and 21 days did not differ from one another $(899 \pm$ 47 vs. $1048 \pm 46 \mathrm{~kJ} \mathrm{day}^{-1}, P>0.6$ ) though both were significantly lower than metabolizable energy at 35 days $\left(2150 \pm 196 \mathrm{~kJ} \mathrm{day}^{-1}\right)$.

The daily energy expenditure of free-ranging loon chicks increased nonlinearly with increasing body mass, and DEE was significantly related to body mass according to the following polynomial regression equation: $\log _{10}$ DEE $\left(\mathrm{kJ}\right.$ day $\left.^{-1}\right)=14.2-8.3 \times$ $\log _{10}$ mass $(\mathrm{g})+1.5 \times \log _{10} \operatorname{mass}^{2}(\mathrm{~g})\left(r^{2}=0.87, P<\right.$ 0.0001, $n=17$; Fig. 1).

The age-related differences in energy flow were partly explained by differences in body mass, as revealed by ANCOVA. Daily energy expenditure, for example, was significantly related to body mass $(F=$ $7.8, \mathrm{df}=1$ and $13, P=0.015$; both $\log$ transformed, with slope $=0.75)$ as well as age $(F=23.8, \mathrm{df}=2$ and $13, P<0.0001)$, with no significant interaction between the two $(P>0.5)$. Likewise, metabolizable energy was significantly related to body mass $(F=$ $8.1, \mathrm{df}=1$ and $13, P=0.014$; both $\log$ transformed, with slope $=0.73)$ as well as age $(F=11.8, \mathrm{df}=2$ and $13, P=0.0012)$, with no significant interaction between the two $(P>0.5)$.

Discussion.-Loons chicks are precocial in terms of locomotion and sensory organs (Starck and Ricklefs 1998), but they rely on their parents to provide them 
with food during part of their postnatal development period (Barr 1996). Loon chicks start to chase and capture fish at an early age (2-3 weeks posthatch; Barr 1996), although their rate of success is low at this age ( $\sim 3 \%$; Barr 1996), and they gain independence in feeding by week 11 posthatch (Barr 1996). Therefore, foraging costs would not have been an important factor in overall energy expenditures during the time frame of this study (between 10 and 35 days posthatch).

Because loon chicks complete their growth in approximately 10-12 weeks, and that energy requirements tend to peak just before fledging (metabolizable energy intake $\sim 3,300 \mathrm{~kJ} \mathrm{day}^{-1}$; F. Fournier et al. unpubl. data), our measures presumably did not correspond to a time when energy requirements were at their greatest (Weathers 1996). Below are three notable features of loon energetics.

First, we found that the pattern of variation in daily energy expenditures of loon chicks was not explained mainly by variation in body mass, as one might expect from interspecies allometric equations for adult birds (Nagy et al. 1999) or juvenile birds (e.g. eq. 13.16 in Weathers 1996). Age was a significant factor independent of the body mass effect. One possible explanation is that developmental changes in thermoregulation might contribute to a nonlinear relation between DEE and body mass in a growing aquatic bird.

The ability to precisely maintain a core body temperature when faced with variations in ambient temperature has been used as a criterion for precociality (Starck and Ricklefs 1998). Most studies on development of homeothermy of precocial chicks have been measures of their thermoregulatory ability in air (Visser 1998, and references therein), and results have shown that most precocial birds achieve homeothermy early in their development (Visser 1998), but there are exceptions to that pattern (Sutter and MacArthur 1992). It must be noted, however, that much less information is available on development of homeothermy in water for precocial aquatic species, and that point is important because the latter species may be faced with a greater thermoregulatory challenge because of the higher rate of heat loss in water.

The loss of body heat by thermal conductance is greater in water than in air (Schmidt-Nielsen 1990), and this may be an important source of heat loss, and thus a source of increased energy expenditures, for young aquatic birds. If there is a developmental change in thermal conductance that results from an increase in the effectiveness of the vasomotor control of the periphery of the hind limbs (Visser 1998), it may be that younger chicks have a higher thermal conductance than older birds. For example, American Coot (Fulica americana) chicks are precocial and are on the water very soon after hatching but they do not achieve homeothermy until eight days posthatch (Sutter and MacArthur 1992). Additionally, Ameri- can Coot chicks less than seven days old are brooded frequently by their parents during the day, and it has been suggested that the time required to reach homeothermy may be related to the length of the brooding period (Ricklefs and Roby 1983); the longer the brooding period, the longer it takes the nestling to achieve homeothermy. The same may be true for loon chicks. During the first seven to eight days posthatch, loon chicks spend part of the day riding on the backs of their parents, and brooding chicks by backriding may serve to protect them from predators, facilitate thermoregulation, and hence delay the development of homeothermic independence (McIntyre 1975). If loon chicks do indeed show a developmental change in their ability to thermoregulate, and if they achieve homeothermy around 10 days posthatch but stop being brooded by their parents around day 8 , then that could explain their high energy expenditures at 10 days when compared to 21 day-olds, and hence explain the nonlinearity in energy expenditures. The difference could also be that thermal conductance in the hind limbs is greater in younger loon chicks than in older chicks, as discussed above (Visser 1998). Unfortunately, these explanations remain speculative for the moment because no information is available on metabolism of loon chicks, the importance of brooding on thermoregulatory costs, and thermal conductance.

The second notable point about loon chick energetics is that, for their size, 10 day old loon chicks had relatively high daily energy expenditures. In most studies of energetics, total energy expenditures (kilojoules per day) increase with body size, with smaller individuals expending less energy than larger ones. However, our results show that 10 day old loon chicks had similar expenditures as 21 day old chicks. That is possibly related to factors discussed above, but whatever the explanation, the difference emphasizes that our knowledge of chick energetics is rather limited (certainly compared with that for adults), and predictions based solely on body mass may not be accurate.

These differences in energetics between loon chicks and other avian species that have been studied underscore the importance of direct measurements over allometric prediction for the most accurate estimation of food intake and exposure to toxins in food, which was the primary motivation of this study and the third issue for discussion. Food intake can be estimated from our results as the quotient of the loons' daily metabolizable energy (in kilojoules per day) and the metabolizable energy content of their diet (in kilojoules per day wet mass). The metabolizable energy is defined as the total amount of energy expended and includes costs of locomotion, thermoreguation, and tissue synthesis (Weathers 1996). The metabolizable energy content of the diet represents the amount of energy that is assimilated by the organism, and is directly proportional to the assim- 
ilation efficiency of the organism for the food resource (Karasov 1990). For now, we use a mean value for other avian piscivores, though we are completing balance trials on captive loons. Assuming fish with a water content of $70 \%$ and $17.7 \mathrm{~kJ}$ metabolizable energy per gram dry matter (Karasov 1990), we estimate that free-living loon chicks between the ages of 10 and 35 days consume 162-383 g wet fish per day. By comparison, the median daily consumption of fish in adult female (United States) humans is $31 \mathrm{~g}$ wet mass per day. Methyl mercury levels in fish consumed by loon chicks, and presumably humans, in Wisconsin vary according to particular lake characteristics (Meyer et al. 1998) but range 0.1-0.5 $\mu \mathrm{g} \mathrm{g}^{-1}$ fresh mass. Thus, $\mathrm{Hg}$ exposure levels would be in the range of 16-192 $\mu \mathrm{g} \mathrm{day}^{-1}$ for loon chicks and 3-16 $\mu \mathrm{g}$ day $^{-1}$ for humans, although not all the $\mathrm{Hg}$ is absorbed. If we express those values of daily intake of fish per unit body mass, we obtain values of 191-341 $\mathrm{g}$ fish per kilogram of body mass per day in loon chicks and $0.6 \mathrm{~g}$ fish per kilogram of body mass per day in humans, and the mass-specific intake of $\mathrm{Hg}$ is 19-171 $\mu \mathrm{g}$ per kilogram of body mass per day for loon chicks and $0.06-0.3 \mu \mathrm{g} \mathrm{Hg}$ per kilogram of body mass per day for humans. The current acceptable daily intake guideline that safeguards humans against the deleterious effect of $\mathrm{Hg}$ is $0.47 \mu \mathrm{g}$ per kilogram of body mass per day (World Health Organization, cited in Kuhnlein and Chan 2000). Our comparison demonstrates that the intake of $\mathrm{Hg}$ in loon chicks far exceeds exposure levels that are considered hazardous in humans, and that is mainly due to the allometric scaling of food intake.

Although the determination of energetics of nestlings with DLW has been traditionally used to assess the effect of nestling energy requirements on setting energy limitations on a parent's reproductive success, this study outlines the potential for using the DLW method to address questions in wildlife toxicology. More specifically, the energy requirements of nestlings can be used in a bioenergetic model of the bioaccumulation of toxicants that incorporates growth, energetics, food intake, and assimilation efficiency. Our study exemplifies the potential collaboration between physiological ecologists interested in energetics and wildlife toxicologists interested in understanding the mechanisms of toxicant uptake and accumulation.

Acknowledgments.-We sincerely thank T. Daulton, B. Fevold, J. Hartigan, S. Gillum, H. O'Brien, and M. Parara for their help during captures. We would also like to thank Dr. D. Schoeller for his advice on DLW and for letting us use his equipment to analyze our samples, and F.F. would especially like to thank T. Shriver for assistance during isotope analyses. Financial support for this project was provided by the Electric Power Research Institute, Wisconsin Department of Natural Resources, and the U.S. Department of the Interior, Geological Survey Biological Resouces Division.

\section{Literature Cited}

BARR, J. F. 1996. Aspects of Common Loon (Gavia immer) feeding biology on its breeding ground. Hydrobiologia 321:119-144.

DRENT, R. H., AND S. DAAN. 1980. The prudent parent: Energetic adjustments in avian breeding. Ardea 68:225-252.

Evers, D. C. 1992. A replicable capture method for adult and juvenile Common Loons on their nesting lakes. Pages 214-220 in Proceedings from the 1992 Conference on the Loon and its Ecosystem: Status, Management, and Environmental Concerns (L. Morse, S. Stockwell, and M. Pokras, Eds.). U.S. Department of the Interior, Fish and Wildlife Service. Concord, New Hampshire.

Gessaman, J. A., AND K. A. NAGy. 1988. Energy metabolism: Errors in gas-exchange conversion factors. Physiological Zoology 61:507-513.

Karasov, W. H. 1990. Digestion in birds: Chemical and physiological determinants and ecological implications. Studies in Avian Biology 13:391415.

Karasov, W. H., AND M. W. Meyer. 2000. Testing the role of contaminants in depressing avian numbers. Revisita Chilean Historia Naturale 73:461471.

Kuhnlein, H. V., AND H. M. Chan. 2000. Environment and contaminants in traditional food systems of northern indigenous peoples. Annual Review of Nutrition 20:595-626.

MCINTYRE, J. W. 1975. Biology and behavior of the Common Loon (Gavia immer) with reference to its adaptability in a man-altered environment. Ph.D. dissertation, University of Minnesota, St. Paul.

Meyer, M. W., D. C. Evers, J. J. Hartigan, And P. S. RASMUSSEN. 1998. Patterns of Common Loon (Gavia immer) mercury exposure, reproduction, and survival in Wisconsin, USA. Environmental Toxicology and Chemistry 17:184-190.

NAGY, K. A. 1980. CO 2 production in animals: Analysis of potential errors in the doubly labeled water method. American Journal of Physiology 238: R466-R473.

NAGY, K. A., I. A. GirARD, AND T. K. Brown. 1999. Energetics of free-ranging mammals, reptiles, and birds. Annual Review of Nutrition 19:247277.

Ricklefs, R. E., AND D. D. Roby. 1983. Development of homeothermy in the diving petrels Pelecanoides urinatrix exsul and P. georgicus, and the Antarctic Prion Pachhyptila desolata. Comparative Biochemistry and Physiology, Series A 75:307311. 
Schmidt-Nielsen, K. 1990. Animal Physiology: Adaptation and Environment. Cambridge University Press, Cambridge, United Kingdom.

StarcK, J. M., AND R. E. Ricklefs. 1998. Patterns of development. Pages 3-30 in Avian Growth and Development (J. M. Starck and R. E. Ricklefs, Eds.). Oxford University Press, Oxford.

Sutter, G. C., AND R. A. MACArthur. 1992. Development of thermoregulation in a precocial aquatic bird, the American Coot (Fulica americana). Comparative Biochemistry and Physiology, Series A 101:533-543.

VISSER, G. H. 1998. Development of temperature regulation. Pages 117-156 in Avian Growth and De- velopment (J. M. Starck and R. E. Ricklefs, Eds.). Oxford University Press, Oxford.

VISSER, G. H., AND H. SCHEKKERMAN. 1999. Validation of the doubly labeled water method in growing precocial birds: The importance of assumptions concerning evaporative water loss. Physiological and Biochemical Zoology 72:740749.

WeAthers, W. W. 1996. Energetics of postnatal growth. Pages 461-496 in Avian Energetics and Nutritional Ecology (C. Carey, Ed.). Chapman and Hall, New York.

Received 25 July 2001, accepted 8 June 2002.

Associate Editor: W. H. Hohman

The Auk 119(4):1126-1132, 2002

\title{
Are Traditional Methods of Determining Nest Predators and Nest Fates Reliable? An Experiment with Wood Thrushes (Hylocichla mustelina) Using Miniature Video Cameras
}

\author{
Gary E. Williams ${ }^{1}$ and Petra Bohall WoOd \\ West Virginia Cooperative Fish and Wildlife Research Unit, Biological Resources Division, U.S. Geological Survey \\ and Division of Forestry, West Virginia University, Morgantown, West Virginia 26506, USA
}

\begin{abstract}
We used miniature infrared video cameras to monitor Wood Thrush (Hylocichla mustelina) nests during 1998-2000. We documented nest predators and examined whether evidence at nests can be used to predict predator identities and nest fates. Fifty-six nests were monitored; 26 failed, with 3 abandoned and 23 depredated. We predicted predator class (avian, mammalian, snake) prior to review of video footage and were incorrect $57 \%$ of the time. Birds and mammals were underrepresented whereas snakes were over-represented in our predictions. We documented $\geq 9$ nest-predator species, with the southern flying squirrel (Glaucomys volans) taking the most nests $(n=8)$. During 2000, we predicted fate (fledge or fail) of 27 nests; 23 were classified correctly. Traditional methods of monitoring nests appear to be effective for classifying success or failure of nests, but ineffective at classifying nest predators.
\end{abstract}

RÉsumé.-Utilizamos cámaras de video en miniatura de infrarrojo para monitorear nidos de Hylocichla mustelina entre 1998 y 2000. Documentamos a los depredadores de los nidos y examinamos si la evidencia en los nidos puede ser usada tanto para predecir las identidades de los depredadores como para predecir el destino de los nidos. Se monitorearon 56

\footnotetext{
${ }^{1}$ E-mail: gwillia5@wvu.edu
}

nidos; 26 fallaron, 3 fueron abandonados y 23 depredados. Predijimos el tipo de depredador (ave, mamífero o serpiente) antes de revisar las imágenes de video. Nuestras predicciones fueron incorrectas el $57 \%$ de las veces, y subestimaron a las aves y los mamíferos mientras que sobrestimaron a las serpientes. Documentamos $\geq 9$ especies depredadoras de nido, siendo la ardilla voladora del sur (Glaucomys volans) la que depredó el mayor número de nidos ( $n$ $=8$ ). Durante el año 2000, predijimos el destino (emplumamiento o falla) de 27 nidos; 23 fueron correctamente clasificados. Los métodos tradicionales de monitoreo de nidos parecen ser eficaces para determinar el éxito o fracaso de los nidos, pero ineficaces para determinar la identidad de los depredadores de nido.

As species of Nearctic-Neotropical migrant songbirds experience population declines (Sauer et al. 1999), the identification and management of limitations upon their populations becomes critical. Predation on eggs and nestlings of songbirds is often the primary cause of nest failure (Martin 1992) and may under some circumstances limit fecundity (Robinson 1992, Trine 1998, Schmidt and Whelan 1999), contributing to population declines (Sherry and Holmes 1992). Therefore, determining the suite of nest predators, especially common ones, of a songbird species 
is an essential step in formulating effective prescriptions for management of its breeding habitat. A variety of methods have been used to identify songbird nest predators with varying success (Major 1991, Thompson et al. 1999, Farnsworth and Simons 2000). Funds for breeding habitat management could be allocated more efficiently if accurate methods for identifying nest predators were developed.

The majority of studies of nesting success have been conducted using periodic inspections of the nest and surrounding area to assess fates of nesting attempts (Martin and Geupel 1993). These methods also are used to classify causes of failure (e.g. predation, abandonment, weather) and specific predators or classes of predators (Best 1978, Wray et al. 1982, Christman and Dhondt 1997, Johnson 1997). Although others have suggested that predators cannot be inferred from inspection of sites of depredated nests (reviewed in Larivière 1999), evaluations of the technique using active nests are rare (but see Thompson et al. 1999, Pietz and Granfors 2000). Video cameras-especially those with infrared and time-lapse capabilities-can unambiguously document nest predation and nesting success, and are thus useful tools for assessing the validity of traditional methods of determining nest outcomes and predator identities. Here, the results of a study of Wood Thrush (Hylocichla mustelina) nest predators are presented in which videotapes of nests were used to address two primary questions: (1) Which species commonly depredate Wood Thrush nests in our study area? and (2) Can evidence at nests be used to predict predator identities and nest fates?

Study area and methods.-The study area, located in the northwestern Monongahela National Forest, West Virginia, falls within the Allegheny Mountains and is characterized by mature forest, steep slopes, diverse plant assemblages, and $115-150 \mathrm{~cm}$ of precipitation annually (Strausbaugh and Core 1978, Demeo 1999). Wood Thrush nests were located through behavioral cues and systematic searches (Martin and Geupel 1993) of likely nesting habitat (Buckelew and Hall 1994).

During the nesting seasons of 1998-2000, we used miniature infrared video camera and time-lapse video recorder systems (Fuhrman Microcam2 [Sim [Seabrook, Texas] camera + Fieldcam LCTLV timelapse VCR. [Use of trade names does not constitute endorsement by the federal government.]) to monitor the nests of Wood Thrushes until they fledged young or failed. We used four camera and recorder systems in 1998 and nine in 1999 and 2000. Each system continuously recorded for $24 \mathrm{~h}$ using standard $\mathrm{T}-160$ videocassettes, capturing 4 images $\mathrm{s}^{-1}$ (onethird the speed of standard VCRs). The cameras record black-and-white images and emit infrared light at $950 \mathrm{~nm}$, a wavelength not visible to vertebrate species (Aidley 1971). In complete darkness, the infrared emitters illuminate objects up to $1 \mathrm{~m}$ from the cam- era. Cameras were attached to substrate near the nest using a clamp arm. The factory-camouflaged camera and clamp arm were modified to incorporate vegetation that matched the plant species of individual nests. Video cameras were connected to the timelapse VCR and 12 volt battery via a $20 \mathrm{~m}$ cable.

Initial camera setup took 2-7 min, with cameras oriented so that the lens was about $30-100 \mathrm{~cm}$ from the nest cup, depending upon the configuration of nest vegetation. VCRs and batteries were placed 10 $20 \mathrm{~m}$ away from the nest behind a tree or other camouflage. VCRs were visited daily to exchange batteries and videocassettes, and nest contents were checked from the VCR site using a remote video monitor. Nests were not directly approached after initial camera setup except when camera views became obstructed. Approaches to recording systems were varied to minimize scent trails.

We predicted identities of nest predators on the basis of evidence in and around the nest during all three years (1998-2000). During 2000, we also predicted nest fates (fledge or fail) using the same methods. After we predicted nest fates and predator identities, we reviewed videotapes to check predictions. A nest was considered finished when daily checks revealed it was empty, when it contained egg or nestling remains, or when it became obvious that it had been abandoned. Finished nests were immediately inspected for evidence of fledging or failure. Signs of fledging included compaction of the nest rim, feces on or below the nest, or parents calling in the vicinity (Martin and Geupel 1993). We did not actively search for fledglings in the nest vicinity except for one instance in 1999 when a predation event on older $(\sim 11$ day) nestlings was not recorded due to equipment failure.

Various cues were used as signs of nest failure. Cold eggs (after incubation had commenced) and no sign of parental attendance were considered signs of abandonment. Portions of nestlings or eggs in or around the nest were considered signs of predation, as was obvious nest disturbance. Disappearance of individuals or broods $\leq 11$ days old was considered indicative of predation (Roth et al. 1996). Rather than predict predator species, we predicted predator class (mammalian, avian, snake). Remains of eggs or nestlings at the nest and highly disturbed nests (i.e. torn nesting materials, nest partially or fully detached from substrate) were considered indicative of mammalian predators (Best 1978, Moors 1983, Westmoreland and Best 1985, Johnson 1997). Lack of egg or nestling remains at nests was considered indicative of a bird or snake predation (Best and Stauffer 1980). Nests with no disturbance of nesting material or nest attachment were assigned as depredated by snakes or birds, depending on nest location (Best 1978, Gottfried and Thompson 1978, Westmoreland and Best 1985). Nests higher in the substrate and with sparse vegetation surrounding them were assigned as dep- 
TABLE 1. Comparisons of daily failure rates $( \pm$ SD) during incubation stage, early nestling stage (age of brood $=0-6$ days), late nestling stage (age of brood $>6$ days), and for combined stages of Wood Thrush nests monitored with cameras $(n=56)$ and monitored using traditional methods $(n=79)$.

\begin{tabular}{lcccc}
\hline \hline \multicolumn{1}{c}{ Comparison } & Daily failure rate & $\begin{array}{c}\text { Observation } \\
\text { days }\end{array}$ & $\chi^{2}$ & $P$ \\
\hline Camera combined & $0.043 \pm 0.008$ & 607 & 0.41 & 0.52 \\
Noncamera combined & $0.037 \pm 0.006$ & 990 & & 0.37 \\
Camera incubation & $0.022 \pm 0.013$ & 134 & 441 & 0.80 \\
Noncamera incubation & $0.036 \pm 0.009$ & 228 & 0.21 & 0.64 \\
Camera early nestling & $0.035 \pm 0.012$ & 287 & 0.59 & 0.44 \\
Noncamera early nestling & $0.028 \pm 0.010$ & 245 & & \\
Camera late nestling & $0.061 \pm 0.015$ & 262 & & \\
Noncamera late nestling & $0.046 \pm 0.013$ & & & \\
\hline
\end{tabular}

redated by birds, whereas lower nests in denser vegetation were assigned to snakes. The criteria used to separate bird and snake predators were based primarily on preferences of black rat snakes for habitat structure that is consistent with forest edges (Durner and Gates 1993, Blouin-Demers and Weatherhead 2001).

We also used traditional methods to monitor a sample of Wood Thrush nests. Nests were visited every $2-4$ days until completion. Nest chronology data were used to plan additional visits on likely hatching and fledging days. Nest contents were verified from a distance whenever possible. We used nest appearance, parental behaviors, and sightings of fledglings near the nest to confirm fledging (Martin and Geupel 1993).

We compared daily failure rates of nests monitored with and without cameras to examine potential biases associated with camera-monitored nests. Additionally, we compared daily predation rates of camera nests among incubation, early nestling (0-6 days) and late nestling (>6 days) stages. We calculated estimates of daily failure and predation rates using the Mayfield (1961, 1975) method, estimated variance after Hensler and Nichols (1981), and used the program CONTRAST to compare failure rates among groups (Sauer and Williams 1989).

Results and discussion.-Fifty-six nests were monitored with cameras during $1998(n=4), 1999(n=$ $24)$, and $2000(n=28)$. Nests were monitored an average of 11 days before fledging or failing (range 123 days). Twenty-six nests failed (46.4\%), including three abandoned. Abandonment occurred after one nest was incubated at least 22 days (average incubation period is 13 days); after nesting substrate shifted, causing another nest to spill its eggs; and after a territorial conflict among three adults resulted in abandonment of a nestling. All other failures $(n=$ $23)$ resulted from predation on nestlings $(n=22)$ or eggs $(n=1)$, with predation events occurring $0-16$ days (mean $=7.8 \pm 4.3$ days) after cameras were placed at the nests. We also monitored 79 noncamera nests during $1998(n=22), 1999(n=37)$, and 2000 $(n=20)$. Daily failure rates of camera and noncamera nests did not differ during any nest stage (Table 1). Because nest abandonment (immediately following camera setup; $n=29$ nests; these nests were excluded from analyses) was higher for nests early in incubation than for nests in later stages, we often deployed cameras shortly before or after hatching. That reduced camera-associated abandonment, but may have resulted in few documented predations of nests with eggs. Mean daily predation rate of nests did increase from incubation through the early and latenestling stages, however $\left(\chi^{2}=10.93, P=0.004\right)$.

We documented $\geq 9$ species of Wood Thrush nest predators (Table 2). Southern flying squirrels were the most frequent, taking eight nests, including seven with nestlings and one with eggs. The southern flying squirrel was the only predator that took nests during all three years of the study. Various raptor species formed the next most common group, depredating seven nests, all with nestlings. Mice were observed taking nestlings on three occasions, but are perhaps more commonly nest scavengers rather than predators (see Table 2). Black rat snakes depredated two nests in 2000. Other predators included a black bear and what appeared to be ants or some other arthropod species (see Table 2). Two predators were not identified due to equipment failure. Of the 23 predations, 15 were nocturnal, 7 were diurnal, and 1 could not be determined due to equipment failure. Alrhough we likely recorded many of the common Wood Thrush nest predators in our study area, we documented new predators each year, suggesting our predator list is incomplete. Presence of video cameras may have attracted some predators and repelled others (Major and Gowing 1994, Pietz and Granfors 2000), which could produce a biased list of nest predators. Although testing for that bias was beyond the scope of our study, the lack of significant differences in daily failure rates between nests monitored with cameras and nests monitored using traditional methods (Table 1) suggests that a similar suite of predators was taking both types of nests at similar rates. 
TABLE 2. Actual predators, predicted predator class, and timing of predation of Wood Thrush nests monitored with video cameras. Class of nest predator (avian, mammalian, snake) was predicted by interpretation of evidence in and around failed nests. Video footage was reviewed afterward to verify predator identity.

\begin{tabular}{|c|c|c|c|c|c|}
\hline \multirow[b]{2}{*}{ Predator species } & \multicolumn{4}{|c|}{ Timing of predation } & \multirow[b]{2}{*}{ Incorrect predictions $(n)$} \\
\hline & Total & $\begin{array}{c}\text { Incuba- } \\
\text { tion }\end{array}$ & $\begin{array}{c}\text { Nest- } \\
\text { lings } \\
0-6 \\
\text { days }\end{array}$ & $\begin{array}{c}\text { Nest- } \\
\text { lings } \\
>6 \\
\text { days }\end{array}$ & \\
\hline Glaucomys volans (southern flying squirrel)a & 8 & 1 & 1 & 6 & avian (1), snake (1), fledge (1) \\
\hline Peromyscus sp. (mouse) & 3 & 0 & 1 & 2 & snake (1), fledge (1) \\
\hline Accipiter sp. & 2 & 0 & 0 & 2 & mammalian (1), fledge (1) \\
\hline Accipiter striatus (Sharp-shinned Hawk) & 1 & 0 & 1 & 0 & snake $(1)$ \\
\hline Strix varia (Barred Owl) & 2 & 0 & 1 & 1 & mammalian (2) \\
\hline Elaphe obsoleta (black rat snake) & 2 & 0 & 1 & 1 & none \\
\hline Buteo platypterus (Broad-winged Hawk) & 1 & 0 & 0 & 1 & none \\
\hline Buteo sp. ${ }^{\text {d }}$ & 1 & 0 & 1 & 0 & mammalian (1) \\
\hline Ursus americanus (black bear) & 1 & 0 & 0 & 1 & none \\
\hline Ants or other arthropods & 1 & 0 & 1 & 0 & snake $(1)$ \\
\hline
\end{tabular}

\footnotetext{
a Includes one predation event where both a southern flying squirrel and a mouse took nestlings. A southern flying squirrel made the initial attack on the nest and was the cause of damage to the cup, which led us to predict a mammalian predator. The mouse removed a nestling from the nest $\sim 1.1 \mathrm{~h}$ after the southern flying squirrel had left the nest ( $1.7 \mathrm{~h}$ after the initial attack).

${ }^{\mathrm{b}}$ Includes a predation event where, for unknown reasons, the brooding female flushed from the nest shortly after dusk. The mouse attacked the unattended nest containing the 4 -day-old brood $\sim 6 \mathrm{~h}$ later. Neither parent returned until the following morning, when all the nestlings were dead.

c Predator was either A. striatus (Sharp-shinned Hawk) or A. cooperii (Cooper's Hawk).

d Predator was either B. jamaicensis (Red-tailed Hawk) or B. lineatus (Red-shouldered Hawk).

e Ants or other arthropods were not seen. We based our conclusion on the behaviors of the adult female, who constantly pecked at unseen objects in the nest over the course of the $\geq 16 \mathrm{~h}$, and the 6-day-old brood, who writhed as though they were trying to shake something from their bodies and ultimately jumped from the nest during the night.
}

Predator class (avian, mammalian, snake) was predicted from sign for the 21 depredated nests for which videotaped evidence was available (Table 2). Predator class was incorrectly assigned to 12 nests. Bird and mammal predations were underestimated, whereas snake predations were overestimated in predictions. Although raptors took seven nests, only one was correctly classified as an avian predator, with most attributed to mammals $(n=4)$. Both instances of predation by black rat snakes were correctly classified as snakes. However, snakes were incorrectly implicated in predations by a mouse, Sharp-shinned Hawk, southern flying squirrel, an unidentified predator(s) that appeared to be ants, and a case of nest abandonment. Of 11 nests depredated by mammals, only 6 were correctly assigned.

During 2000, nest fates were predicted for 27 nests using traditional methods. Predicted fates were then compared with outcomes recorded on videotapes. We correctly classified fate for 23 of 27 nests. We incorrectly classified two depredated nests as fledged, one fledged nest as depredated, and one abandoned nest as depredated. Nestlings were $\geq 10$ days old in both depredated nests that were misclassified as fledged. Overall success or fail ratio and daily survival rates were similar for predicted fates (16 fledged, 11 failed; daily survival rate $=0.97$ ) and actual fates (15 fledged, 12 failed; daily survival rate $=$ $0.96)$ of nests.
A number of factors contributed to our inability to predict nest-predator class from evidence at the nest. First, as noted in other studies of nest predators (Major 1991, Thompson et al. 1999, Pietz and Granfors 2000), there was high intraspecific variation in evidence left by individual predator species. Southern flying squirrels, for instance, left Wood Thrush remains (feathers, bone, or soft tissue) at five nests, but none at three others. Second, there was interspecific overlap in predation evidence left at nests (see also Thompson et al. 1999; Pietz and Granfors 2000). For example, both raptors and southern flying squirrels left similar evidence at some of the nests they depredated. Finally, adult Wood Thrushes commonly altered depredated nests in a way that would tend to implicate more "clean" predators such as snakes or birds. For instance, we judged the predator of one nest to be avian when the actual predator was a southern flying squirrel because a Wood Thrush carried away a partially eaten nestling left at the nest. Had it not done so, we would have predicted a mammalian predator. Additionally, the appearance of nests can change rapidly after predation. For example, another nest depredated by a southern flying squirrel was correctly classified as a mammal predation the morning following the event because Wood Thrush remains were found below the nest. By happenstance, another researcher reinspected the nest the following day. By that time, the remains had 
disappeared and the second researcher concluded that the nest (which contained 10 day old nestlings at the time of predation) had fledged.

Southern flying squirrels, although known to depredate or scavenge Wood Thrush nests with eggs (Roth et al. 1996, Farnsworth and Simons 2000), had not been documented taking nestlings. In the present study, they were the most common nest predator by a wide margin, taking eight nests; no other species (or genus) of predator took more than three nests. That raises a number of questions. Are commonly implicated nest predators such as raccoons and corvids unimportant in landscapes dominated by mature, mostly contiguous forest, such as the Monongahela National Forest? Do southern flying squirrels frequently depredate songbird nests in other areas? Do mast-producing forests that are heavily dissected with roads and logging trails (potential glideways) provide ideal habitat for southern flying squirrels?

In our study, 9 of the 23 depredated nests contained nestlings that were $\geq 10$ days old, an age considered indicative of nest success in another study of Wood Thrushes (Fauth 2001). Similarly, Thompson et al. (1999), found that predation of Field Sparrow (Spizella pussila) and Indigo Bunting (Passerina cyanea) nests tended to occur late in the nestling period. It is quite possible, even likely, that some studies misclassify fates of nests that are depredated late in the nestling stage, leading to overestimates of nesting success. Although we used traditional methods to assess nest fates, our nests were visited (from a distance of 10-20 m) daily instead of every 3-4 days as is typical for most nesting success studies. Further, we used video monitors to visually confirm nest contents, which likely produced better estimates of nestling ages and likely fledge dates than most traditional studies. Even so, three depredated nests with older nestlings (age of oldest nestling $=13,13$, and 10 days) were classified as fledged prior to review of videotapes. Such events reinforce the importance of carefully monitoring nest chronology and planning visits around likely fledge dates (Martin and Geupel 1993). This study also underscores the importance of locating fledged young in the vicinity of the nest site. Although alarm calls by parents in the vicinity of nests have been suggested as a possible indication of fledging (Martin and Geupel 1993), we found that to be undependable and were frequently scolded by the owners of recently depredated nests.

Finally, although it is advisable to minimize disturbance to nests during checks, it is important to verify contents of nests while they are unattended by adults because parents may continue typical patterns of behavior around nests following predation (Pietz and Granfors 2000). We observed parents returning (usually multiple times) to depredated nests in 19 of 20 cases for which these data are available, generally visiting minutes or hours after diurnal predation events or the morning following nocturnal predation events. Common activities included food deliveries, adjustment of nest materials, removal of remains of eggs or nestlings, and brooding of dead nestlings or the empty nest cup. A researcher using behavioral cues to determine the status of recently depredated nests is likely to judge them as active. Such a mistake would, at the least, skew daily survival estimates upward (i.e. failure to discover predation until the next visit) and could lead to an incorrect assessment of nest fate.

Traditional methods for monitoring nests appear to be effective for classifying success or failure of nests, provided that close attention is paid to chronology and determining nest contents. However, the interpretation of sign at nests to classify nest predators was almost wholly ineffective. Videotaping nests using cameras with infrared capabilities generally provides unambiguous data regarding nest predators and nest fates. This technique is quite labor intensive and expensive, however. For our study, we spent about $\$ 45,000$ for nine camera and VCR systems and associated supplies (but see King et al. 2001 for a less costly alternative). After pilot work, we were able to monitor approximately three nests per system per season. Thompson et al. (1999), however, monitoreded 52 nests in one season using just six camera and recorder systems. The number of nests monitored per system depends on a number of factors, including nest survival rates, length of nesting stages, timing of camera deployment (early vs. late in the nesting cycle), availability of nests, and logistical constraints. Additionally, camera and VCR systems such as the ones we used are not appropriate for inaccessible nests, for example ones that are high in the canopy, at the ends of small diameter limbs. For shrub and ground-nesting songbirds, however, there presently appear to be no equally effective methods of documenting nest predators.

Acknowledgments. - This study was funded by the Biological Resources Division U.S. Department of the Interior, Geological Survey (BBIRD Program and Cooperative Research Units), West Virginia University Research Corporation, West Virginia Division of Natural Resources Nongame Program, and National Forest Foundation. Our study could not have been completed without the hard work of numerous field and laboratory technicians. Patti Newell, Max Oleson, and Rebecca Smith were especially helpful. Tom DeMeo of the U.S. Department of Agriculture Forest Service provided logistical support and helpful advice. West Virginia Cooperative Fish and Wildlife Research Unit and West Virginia University Division of Forestry provided field and laboratory equipment and logistical support. P. Pietz, T. Simons, F. Thompson III, and C. Weakland provided helpful comments on earlier versions of this manuscript. This is scien- 
tific article \# 2823 of the West Virginia University Agriculture and Forestry Experiment Station.

\section{Literature Cited}

Aidley, D. J. 1971. The Physiology of Excitable Cells. Cambridge University Press, London.

BEST, L. B. 1978. Field Sparrow reproductive success and nesting ecology. Auk 95:9-22.

BEST, L. B., AND D. F. STAuffer. 1980. Factors affecting nesting success in riparian bird communities. Condor 82:149-158.

Blouin-Demers, G., And P. J. Weatherhead. 2001. Thermal ecology of black rat snakes in a thermally challenging environment. Ecology 82: 3025-3043.

Buckelew, A. R., JR., And G. A. Hall. 1994. The West Virginia Breeding Bird Atlas. University of Pittsburgh Press, Pittsburgh, Pennsylvania.

Christman, B. J., AND A. A. DHONDt. 1997. Nest predation in Black-capped Chickadees: How safe are cavity nests? Auk 114:769-773.

DemeO, T. E. 1999. Forest songbird abundance and viability at multiple scales on the Monongahela National Forest, West Virginia. Ph.D. dissertation, West Virginia University, Morgantown.

Durner, G. M., AND J. E. Gates. 1993. Spatial ecology of black rat snakes on Remington Farms, Maryland. Journal of Wildlife Management 57: 812-826.

FARNSWORTH, G. L., AND T. R. SimONS. 2000. Observations of Wood Thrush nest predators in a large contiguous forest. Wilson Bulletin 112:82-87.

FAUTH, P. T. 2001. Wood Thrush populations are not all sinks in the agricultural Midwestern United States. Conservation Biology 15:523-527.

GotTfried, B. M., And C. F. Thompson. 1978. Experimental analysis of nest predation in an oldfield habitat. Auk 95:304-312.

Hensler, G. L., And J. D. Nichols. 1981. The Mayfield method of calculating nesting success: A model, estimators, and simulation results. Wilson Bulletin 93:42-53.

JOHNSON, M. S. 1997. The effect of age on nest concealment and its complementary effect on production of Wood Thrush. Wilson Bulletin 109: 68-73.

King, D. I., R. M. DeGraaf, P. J. Champlin, and T. B. Champlin. 2001. A new method for wireless video monitoring of bird nests. Wildlife Society Bulletin 29:349-353.

LARIVIÈRE, S. 1999. Reasons why nest predators cannot be inferred from nest remains. Condor 101: 718-721.

MAJOR, R. E. 1991. Identification of nest predators by photography, dummy eggs, and adhesive tape. Auk 108:190-195.

MAJOR, R. E., AND G. GowING. 1994. An inexpensive photographic technique for identifying nest predators at active nests of birds. Wildlife Research (Australia) 21:657-666.

MARTIN, T. E. 1992. Breeding productivity considerations: What are the appropriate features for management? Pages 455-473 in Ecology and Conservation of Neotropical Migrant Landbirds (J. M. Hagan III and D. W. Johnston, Eds.). Smithsonian Institution Press, Washington, D.C.

Martin, T. E., And G. R. Geupel. 1993. Nest-monitoring plots: Methods for locating nests and monitoring success. Journal of Field Ornithology 64:507-519.

MAYFIELD, H. M. 1961. Nesting success calculated from exposure. Wilson Bulletin 73:255-261.

MAyfield, H. M. 1975. Suggestions for calculating nest success. Wilson Bulletin 87:456-466.

Moors, P. J. 1983. Predation by mustelids and rodents on the eggs and chicks of native and introduced birds in Kowhai Bush, New Zealand. Ibis 125:137-154.

Pietz, P. A., AND D. A. Granfors. 2000. Identifying predators and fates of grassland passerine nests using miniature video cameras. Journal of Wildlife Management 64:71-87.

Robinson, S. K. 1992. Population dynamics of breeding Neotropical migrants in a fragmented Illinois landscape. Pages 408-418 in Ecology and Conservation of Neotropical Migrant Landbirds (J. M. Hagan III and D. W. Johnston, Eds.). Smithsonian Institution Press, Washington, D.C.

Roth, R. R., M. S. JOHNSON, AND T. J. UNDERWOOD. 1996. Wood Thrush (Hylocichla mustelina). In The Birds of North America, no. 246 (A Poole and F. Gill, Eds.). Academy of Natural Sciences, Philadelphia, and American Ornithologists' Union, Washington, D.C.

SAUER, J. R., AND B. K. Williams. 1989. Generalized procedures for testing hypotheses about survival of recovery rates. Journal of Wildlife Management 53:137-142.

Sauer, J. R., J. E. Hines, I. Thomas, J. Fallon, And G. GougH. 1999. The North American Breeding Bird Survey, Results and Analysis 1966-1998, version 98.1. U.S. Department of the Interior, Geological Survey Patuxent Wildlife Research Center, Laurel, Maryland.

SCHMIDT, K. A., AND C. J. WHELAN. 1999. The relative impacts of nest predation and brood parasitism on seasonal fecundity in songbirds. Conservation Biology 13:46-57.

Sherry, T. W., AND R. T. Holmes. 1992. Population fluctuations in a long-distance Neotropical migrant: Demographic evidence for the importance of breeding season events in the American Redstart. Pages 431-442 in Ecology and Conservation of Neotropical Migrant Landbirds (J. M. Hagan III and D. W. Johnston, Eds.). Smithsonian Institution Press, Washington, D.C. 
Strausbaugh, P. D., And E. L. Core. 1978. Flora of West Virginia. Seneca Books, Morgantown, West Virginia.

ThOMpson, F. R., III, W. DiJAK, AND D. E. Burhans. 1999. Video identification of predators at songbird nests in old fields. Auk 116:259-264.

TRINE, C. L. 1998. Wood Thrush population sinks and implications for the scale of regional conservation strategies. Conservation Biology 12: 576-585.
Westmoreland, D., AND L. B. BEST. 1985. The effect of disturbance on Mourning Dove nesting success. Auk 102:774-780.

Wray, T., II, K. A. Strait, And R. C. Whitmore. 1982. Reproductive success of grassland sparrows on a reclaimed surface mine in West Virginia. Auk 99:157-164.

Received 21 August 2001, accepted 6 May 2002. Associate Editor: F. Thompson III

The Auk 119(4):1132-1137, 2002

\title{
Immediate Species Responses to Catastrophic Natural Disturbances: Windthrow Effects on Density, Productivity, Nesting Stand Choice, and Fidelity in Northern Goshawks (Accipiter gentilis)
}

\author{
Vincenzo Penteriani, ${ }^{1,4}$ Marie Mathiaut, ${ }^{2}$ AND Guy Boisson ${ }^{3}$ \\ ${ }^{1}$ Department of Applied Biology, Estación Biológica de Doñana, C.S.I.C., Avda. de María Luisa s/n., Pabellón del \\ Perú, Apdo 1056, 41013 Seville, Spain; \\ 221290 Saint Broing les Moines, France; and \\ ${ }^{3}$ Office National des Forêts (O.N.F.), Côte d'Or Department, 21000 Châtillon-sur-Seine, France
}

\begin{abstract}
In December 1999, an exceptional windstorm traveled across northern France (Côte $\left.\mathrm{d}^{\prime} \mathrm{Or}\right)$. The severity of the stand damages ranged from $<1$ to $>80 \%$, and over $10 \%$ of the overall surface of several homogeneous woodlands (from $\sim 1,000$ to 8,000 ha) was affected by the windstorm. Data were available on Northern Goshawk (Accipiter gentilis) density, productivity, and nesting stand preferences in that area before the disturbance. The species showed tolerance to the natural disturbance induced by the windstorm: we found no difference in density, nesting stand choice, or productivity between the six breeding seasons before the windthrow and in the one immediately after. Breeding pairs moved away $(50-200 \mathrm{~m})$ from their traditional nest stand only when its original structure was altered by $>30 \%$ in the $50 \mathrm{~m}$ surrounding the nest tree. We hypothesize that the Northern Goshawk tolerance to windstorm damage may be the result of an adaptive response, which they have developed under both climate- and human-originated stresses.
\end{abstract}

RÉsuMÉ.-En décembre 1999, une tempête de vent exceptionnelle a traversé le nord de la France (Côte d'Or). La sévérité des dommages portés aux arbres variait de $<1$ à $80 \%$, et plus de $10 \%$ de la surface totale de plusieurs boisés homogènes (de $\sim 1,000$ à 8,000 ha) ont été affectés par la tempête. Des données

\footnotetext{
${ }^{4}$ E-mail: penteriani@ebd.csic.es
}

concernant la densité, la productivité et les préférences du site nidification de l'Autour des palombes étaient disponibles (Accipiter gentilis) dans cette région avant la tempête. L'espèce s'est montrée tolérante aux dérangements de type naturel causés par la tempête: nous n'avons trouvé aucune différence dans la densité, le choix du site de nidification ou la productivité entre les six saisons de nidification avant la tempête et celle immédiatement après. Les couples nicheurs ont quitté (50-200 m) leur lieu traditionnel de nidification seulement dans le cas où la structure d'origine était altérée de $>30 \%$ dans les $50 \mathrm{~m}$ autour du nid. Nous avons émis l'hypothèse que la tolérance de l'Autour des palombes aux dommages de la tempête pourrait être le résultat d'une réponse adaptative qu'ils auraient développée suite à des stress d'origine climatique et humaine.

All naturally occurring and human-disturbed ecosystems are mosaics of environmental conditions, and a large part of that heterogeneity arises from disturbances operating at various temporal and spatial scales. A disturbance may be defined as any relatively discrete event in time that may take place on a variety of spatial scales; that disrupts the ecosystem, community, or population structure; and changes resources, substrate availability, or physical environment (Pickett and White 1985). We refer to "catastrophic disturbance" as an event that occurs so rarely in a given geographic area that it is unlikely to be experienced as a repeated, selective force 
(Harper 1977). Species respond differently to disturbances depending on their ability to exploit disturbed patches, and individual responses may produce changes that are recognizable at the population level: attributes such as density, spatial distribution, mortality and reproductive rate may change (Karr and Freemark 1985).

Major natural disturbances, such as windstorms, have mainly been studied from the standpoint of plant species and systems: few authors have focused their attention on the response of animal species (White and Pickett 1985), and a small number of studies have compared some ecological attributes of a species before and after a disturbance (e.g. Dunning and Watts 1991, Lens and Dhondt 1992, Jones et al. 2001). Interest in natural disturbances stems from their fundamental implications in conservation biology and ecology (e.g. habitat fragmentation, dynamics of biological systems, alteration in reproductive output and nesting place; Pickett and White 1985).

On 26-28 December 1999, a storm considered exceptional in terms of magnitude intensity (wind speed of $80-173 \mathrm{~km} \mathrm{~h}^{-1}$ ) and severity swept northern France (from Brittany to Burgundy), from west to east along the 49th parallel, over a path $>150 \mathrm{~km}$ wide. Winds were accompanied by local rain and snowfalls. The windstorm developed from a deep depression of $\sim 960 \mathrm{hPa}$, and the exceptional wind speed was the result of the interaction between the depression approaching land and the $400 \mathrm{~km} \mathrm{~h}^{-1}$ jet stream at 9,000 $\mathrm{m}$ altitude. In the Côte $\mathrm{d}^{\prime} \mathrm{Or}$ area (Burgundy region, eastern France), forest damage was concentrated in the north: the severity of the stand damage was very variable, ranging from $<1$ to $>80 \%$, and over $10 \%$ of the overall surface of several homogeneous woodlands (from about 1,000 to 8,000 ha) was affected by the windstorm (Office National des Forêts unpubl. data). The stand damage observed in the Côte d'Or forests exhibited a positive relationship with stand age and height, and a negative relationship with stand density; complete damage occurred only in stands of $\geq 100$ years of age (Office National des Forêts unpubl. data).

The nesting stands of the Northern Goshawks (Accipiter gentilis) were particularly affected by that catastrophic event because they nest in the more mature stands of forests characterized by tall trees and high canopy cover (Penteriani 1999a, Penteriani et al. 2001), two elements that increase the stand vulnerability to windthrow (Foster 1988). Detailed data were available on density, productivity, and nesting stand preferences in the area hit by the windstorm for the six years preceding it (Penteriani 1999a). Consequently, we were able to examine the effects of the windthrow on (1) density of breeding pairs; (2) choice of a new nesting stand under the double pressure of the natural disturbance and of the starting of a new reproductive season; (3) productivity (ex- pressed by egg-laying date, number of young per breeding pair and per successful pair); and (4) nesting stand fidelity (what severity of stand structure disturbance led a pair to move away and how far it moved).

Study area and methods.-We evaluated the immediate response of Northern Goshawks to the December 1999 windstorm from January to July 2000, in a forested area of the Côte d'Or of $\sim 700 \mathrm{~km}^{2}$. Wide and homogeneous tracts of broad-leaved trees (Quercus pedunculata, Q. petraea, Fagus sylvatica) with occasional small areas of cropland dominate the area.

Density was estimated by the nearest-neighbor distance method (NND; Newton et al. 1977), and regularity in nest spacing was tested by the G-test of Brown and Rothery (1978). Listening sessions of spontaneous, dawn and morning vocalizations of adults (Penteriani 1999b) were performed during the prelaying period (January-March in our study area) to identify the (new or traditional) stands occupied by a breeding pair after the windstorm. That method has the triple advantage of detecting the presence of breeders in their nesting site (1) with an efficiency of $100 \%$; (2) very early in the breeding season; and (3) with the supplemental information on whether the stand is occupied by a pair or by a single bird only (Penteriani 1999b). A traditional nest stand is a stand where, in the six years preceding the windstorm, a Northern Goshawk pair attempted nesting, successfully or not, without moving away to a possible alternative nesting site. We evaluated the severity of the windthrow damage to the nesting stand structure by estimating by eye the percentage of fallen trees on two spatial scales: $50 \mathrm{~m}$ (the minimum area of mature stand required by the species to select it as a nesting site; Penteriani and Faivre 1997, Penteriani 1999a) and $500 \mathrm{~m}$ of radius around the nest tree.

We assessed the effect of the windthrow by testing ( $t$-test) for possible differences in structure between the nesting stands, before the windstorm $(n=19)$, and the new ones chosen in the reproductive season after the windstorm. In the latter case, only the traditional nesting sites $(n=6)$ from where the pairs moved away because of the windstorm-induced alteration of the original stand structure were considered. We used 4 and 6 variables to describe the nest tree and the nesting stand, respectively: diameter at breast height $(\mathrm{DBH})$, height and crown volume of the nest and stand trees, mean distance between the nest tree and nearest surrounding trees, mean distance between stand trees, stand canopy cover and flight space (for the description and computation of the above variables, see Penteriani and Faivre 1997). The selected variables-that is, those most commonly used in the analysis of Northern Goshawk nesting habitats (Bosakowski 1999, Penteriani 1999a)—also proved to be important in the description of the nest site structure (Penteriani and Faivre 1997, Penteriani et al. 2001). Characteristics of the nesting stand in- 
TABLE 1. Comparison ( $t$-test) of the structure $(\bar{x} \pm$ SD) of Northern Goshawk nesting stand before $(n=19)$ and after $(n=6)$ the windthrow.

\begin{tabular}{|c|c|c|c|c|}
\hline & Before windthrow & After windthrow & $t$-test & $P$ \\
\hline \multicolumn{5}{|c|}{ Nest tree characteristics } \\
\hline Diameter at breast height $(\mathrm{m})$ & $0.49 \pm 0.1$ & $0.48 \pm 0.1$ & 0.135 & 0.89 \\
\hline Height (m) & $26.1 \pm 4.2$ & $26.2 \pm 3.8$ & -0.032 & 0.97 \\
\hline Crown volume $\left(\mathrm{m}^{3}\right)$ & $3665.9 \pm 1427.0$ & $3658.7 \pm 998.3$ & 0.007 & 0.99 \\
\hline Distance from surrounding trees $(\mathrm{m})$ & $7.7 \pm 2.3$ & $7.4 \pm 1.4$ & 0.334 & 0.74 \\
\hline \multicolumn{5}{|c|}{ Nest stand tree characteristics } \\
\hline Diameter at breast height $(\mathrm{m})$ & $0.21 \pm 0.1$ & $0.16 \pm 0.1$ & 0.938 & 0.36 \\
\hline Height $(\mathrm{m})$ & $31.4 \pm 8.2$ & $33.5 \pm 6.2$ & -0.567 & 0.58 \\
\hline Crown volume $\left(\mathrm{m}^{3}\right)$ & $3442.4 \pm 2121.6$ & $2566.1 \pm 925.5$ & 0.972 & 0.34 \\
\hline Tree distances $(\mathrm{m})$ & $5.8 \pm 2.1$ & $7.7 \pm 2.1$ & -1.881 & 0.07 \\
\hline Canopy cover $(\%)$ & $91.4 \pm 3.7$ & $91.3 \pm 4.2$ & 0.020 & 0.98 \\
\hline Flight space $\left(\mathrm{m}^{3}\right)$ & $70.0 \pm 29.3$ & $76.6 \pm 21.8$ & -0.506 & 0.62 \\
\hline
\end{tabular}

side a plot of 1 ha around the nest tree were measured. The Mann-Whitney $U$-test was used to identify possible differences in productivity (number of fledged young per breeding pair and per successful pair): (1) between the pairs $(n=19)$ reproducing before the windthrow (as the number of years during which each nest site was monitored was different, we used the mean number of young to avoid pseudoreplications) versus pairs reproducing in the breeding season after the windthrow, and (2) between the pairs $(n=13)$ that reproduced in their original stands after the windthrow, and the pairs $(n=6)$ that moved to a new stand for breeding, after the windthrow-induced damage. A mixed-model analysis of variance (ANOVA) was used to test for differences in the number of young per breeding pair and egg-laying date, before the windthrow and in the reproductive season immediately after the windthrow, for the same nesting stand $(n=19)$. In the mixed-model ANOVA (model III; dependent variables = productivity and egg-laying date), the windstorm was con-

TABle 2. Comparisons of Northern Goshawk productivity parameters $(\overline{\mathrm{x}} \pm \mathrm{SD}, n$; Mann-Whitney $U$-test) before and after the windthrow.

\begin{tabular}{|c|c|c|}
\hline & $\begin{array}{c}\text { Before } \\
\text { windthrow }\end{array}$ & $\begin{array}{c}\text { After } \\
\text { windthrow }\end{array}$ \\
\hline $\begin{array}{l}\text { Young per breed- } \\
\text { ing pair }\end{array}$ & $\begin{array}{l}1.7 \pm 0.4 \\
(n=19) \\
z=-0.3\end{array}$ & $\begin{array}{l}1.5 \pm 1.2 \\
(n=19) \\
=0.72\end{array}$ \\
\hline $\begin{array}{l}\text { Young per } \\
\text { successful pair }\end{array}$ & $\begin{array}{l}1.9 \pm 0.4 \\
(n=19) \\
z=-1.6\end{array}$ & $\begin{array}{l}2.2 \pm 0.6 \\
(n=13) \\
=0.09\end{array}$ \\
\hline $\begin{array}{l}\text { Young per breed- } \\
\text { ing pair }\end{array}$ & $\begin{array}{l}\text { (in traditional } \\
\text { stands) } \\
\text { (in new stands } \\
\quad z=-0\end{array}$ & $\begin{array}{l}1.4 \pm 1.3 \\
(n=13) \\
1.8 \pm 1.0 \\
(n=6) \\
=051\end{array}$ \\
\hline $\begin{array}{l}\text { Percentage suc- } \\
\text { cessful pairs }\end{array}$ & 78.9 & 68.0 \\
\hline
\end{tabular}

sidered as the fixed factor (dichotomous variable: 0 = no windthrow, 1 = windthrow), and the nesting stand as the random factor (Sokal and Rohlf 1995).

When data were not normally distributed, they were $\log _{\mathrm{e}}$ transformed, square-root transformed, or arcsine-square-root-transformed as necessary (Sokal and Rohlf 1995). All the means are given with \pm SD, all tests are two-tailed, and statistical significance was set at $P<0.05$. We used the SPSS (Chicago, Illinois) 10.0 software package.

Results.-The minimum distances between breeding pairs, prior to the windstorm, averaged $2.8 \pm$ $0.58 \mathrm{~km}$, and the values of 0.98 for the G-test indicated a regular distribution of nests within the study area. The pre-windstorm density was equal to 6.7 breeding pairs per $100 \mathrm{~km}^{2}$ (Penteriani 1999b). The minimum distance between breeding pairs in the season following the windstorm averaged $2.7 \pm 0.6$ $\mathrm{km}$, and the values of the G-test and density were the same as those recorded until 1999.

No significant difference was detected in stand structure between nesting stands chosen before and immediately after the windstorm (Table 1).

No difference was detected either between pair productivity values before and in the breeding season following the windthrow or between the pairs reproducing in their original stands and ones that moved to a new stand for breeding after the windthrow (Table 2). When considering the same nesting stand before and after the windstorm, we found no difference in number of fledged young per breeding pair $(F=0.17, \mathrm{df}=1$ and $50, P=0.69)$ or in the egglaying date (last week of March to the second week of April: $F=0.85$, df $=1$ and $50, P=0.36$ ).

With regard to percentages of stand damage recorded in the 19 nesting stands affected by windthrow, we observed that pairs $(n=6)$ moved away to reproduce only when the original stand structure was altered by $>30 \%$ in the $50 \mathrm{~m}$ surrounding the nest tree. In stands where multiple nests were present, the pair always 
chose the one surrounded by forest with the least percentage of damage $(\leq 30 \%)$, even if it differed from the one used in the preceding reproductive seasons. Higher percentage of stand damage in the $500 \mathrm{~m}$ surrounding the nest tree never caused a departure of the pair from the traditional nest stand if the damage in the $50 \mathrm{~m}$ around the nest tree was $<30 \%$. The only case in which a Northern Goshawk pair tried to reproduce in a stand with $>30 \%$ of damage in the $50 \mathrm{~m}$ around the nest tree $(50 \%$ in the $50 \mathrm{~m}$, and $60 \%$ in the $500 \mathrm{~m}$ ) failed after egg-laying, but the cause was impossible to determine.

As to the pairs that moved away after alteration of $>30 \%$ of the original stand structure, in four cases $(66.7 \%)$ the pairs moved to the nearest neighboring stand portion (50-70 m) not affected by the windstorm or altered by $<30 \%$ and, in two cases (33.3\%), the pair moved to a stand located $>50 \mathrm{~m}$ away from the original (70 and $200 \mathrm{~m}$ ), that is, at the borderline between the damaged stand and the undamaged one. In three out of the six above-cited cases, stand alteration also coincided with nest tree destruction.

Before the windstorm, no breeding failure had been observed to result from the lack of a mate in the pair (V. Penteriani unpubl. data). For the first time, in the reproductive season following the storm, we recorded the presence of a lone female in each of three traditional nesting stands (50\% of the breeding failures). Those females-as opposed to the relatively silent ones that incubate (Penteriani 2001)—continued their vocal activity throughout the incubation period, giving the alarm call when intruders came into their nesting stand near the latest active nest.

Discussion.-Two complementary approaches may be taken when studying the effect of disturbances on vertebrates. First, we measure and evaluate the effect of a given disturbance; second, we analyze the immediate responses of vertebrates and interpret them in the context of past disturbance regimes, of either natural or anthropogenic origin. Both of these approaches concerning response to such a drastic environmental stochasticity might give useful conservation and management information: the understanding of internal mechanisms and external influences contributing to changes in a population and of how they interact provide a basis for building models for conservation and wildlife management (Starfield and Bleloch 1991).

The assimilative and adaptive capacity of a species determines its responses to disturbances and the effects of such disturbances on its behavior and ecology: the fitness of a species is not predetermined, it is the result of its evolution under a combination of natural and artificial, local constraints. In this context, different populations of the same species can react differently when they are exposed to different environmental and biological pressures (Pickett and White 1985, Mönkkönen and Welsh 1994, Kenward 1996).
The Northern Goshawk population in our study area showed tolerance to the natural disturbance due to the windstorm in the breeding season immediately after the catastrophic event: nest stand selection showed similar values under both undisturbed and disturbed landscape conditions, and all the investigated parameters of density and productivity displayed fairly similar values before and after the disturbance. The lower percentage of successful pairs was due to the high mortality recorded among males after the storm, with no precedent in the six years prior to the event. A direct effect of the windstorm on our population could explain the higher mortality rate of individuals, hidden by territory reoccupancy by "floaters," but that was not actually detected during our study. Nevertheless, we think it is important to underline that our results only concern the immediate response of the species to the windthrow. Actually, there may be a time-lag in response, for example possible effects on fecundity could appear later when prey population have had time to respond to windfalls.

With regard to nest stand occupation and the observed short-distance movements after a severe stand structure disturbance, we can conclude that breeding pairs showed long term fidelity to their nesting stand, as long as the cover reduction did not exceed the above-mentioned threshold. The removal of $>30 \%$ of the original tree cover increases the risks of predation and exposure to adverse weather conditions, therefore inducing individuals to leave their nesting stand (Robinson et al. 1995, Kenward 1996).

Prior analyses of the stand structure (Penteriani and Faivre 1997, Penteriani et al. 2001) revealed that nests are always found in the most mature portion of a tall tree stand, the size and distinctive features of which decrease with distance from the nest $(50 \mathrm{~m}$ away from the nest tree, the stand structure has already changed). These structural data, combined with the responses of the species to the natural disturbance, highlight that the mature portion of the stand necessary for successful reproduction is limited in space $(\sim 1 \mathrm{ha})$. Northern Goshawks also appear to reproduce successfully if the disturbance-induced damage is below the $30 \%$ threshold in the nest surroundings or far from the 1 ha "buffer" zone around the nest, provided that it does not occur during the reproductive season.

Historically, ecologists have been slow to recognize the importance of disturbances to species and to the heterogeneity that they generate. The notion of a presumed natural equilibrium (climax) of biological systems, the fact that disturbances are regarded as exceptional events (rather than as extremes on a gradient of disturbance intensities), and that variability is often assumed to reflect noise or sampling inefficiencies (rather than real dynamics of biological systems), are the key factors responsible for the slow progress in this area (Karr and Freemark 1985). In 
larger ecological contexts, the adjustment of this European population of Northern Goshawk to catastrophic natural disturbances may be part of a wider process of adaptation of Palearctic species started during the disturbances of Pleistocene glaciations, which were characterized by long timescales, high severity, and large extent within the European continent (Mönkkönen and Welsh 1994). Additionally, our Northern Goshawk population was submitted to strong human-induced alteration (e.g. logging) for several centuries, as were the majority of the European populations. Penteriani and Faivre (2001) showed that the species can tolerate well the first two steps of regeneration felling that characterize the shelterwood system, moving away from their traditional nesting stand only when the windthrow damage exceeded the threshold of $30 \%$. We hypothesize that the tolerance to windstorm damage may be an adaptive response, which this species has been developing under both Pleistocenic and long-term anthropogenic disturbances.

The response of this population has fortunate implications for management. It implies that populations stressed by long timescale disturbances seem to react well today to natural stochastic events. This population could represent a unique example of how long-term perturbations might "prepare" the individuals to better face unpredictable catastrophic events that affect the population dynamic in a stochastic way. This could be particularly important in the present situation in which global climatic change may determine more and more future catastrophic events.

Acknowledgments.-We thank S. Quinto (Office National des Forêts, Dijon Ouest, France) for her precious help in the collection of data on the windstorm damage in the Côte d'Or forests. J. B. Dunning, Jr., M. Ferrer, R. J. Fuller, F. Hiraldo, M. Mönkkönen, S. Saraceni, and V. Selås provided helpful comments on the first draft of the manuscript. This study was supported by a grant from the Estación Biológica de Doñana/Consejo Superior de la Investigación Científica (Spain).

\section{Literature Cited}

BosAKOWSKI, T. 1999. The Northern Goshawk: Ecology, Behavior and Management in North America. Hancock House, Blaine, Washington, D.C.

BROWN, D., AND P. ROTHERY. 1978. Randomness and local regularity of points in a plane. Biometrica 65:115-122.

DunNing, J. B., AND B. D. WATTS. 1991. Habitat occupancy by Bachman's Sparrow in the Francis Marion National Forest before and after hurricane Hugo. Auk 108:723-725.

Foster, D. R. 1988. Species and stand response to catastrophic wind in Central New England, USA. Journal of Ecology 76:135-151.

Harper, J. L. 1977. Population Biology of Plants. Academic Press, New York.
Jones, J., R. D. DeBruyn, J. J. BARG, AND R. J. RobERTSON. 2001. Assessing the effects of natural disturbance on a Neotropical migrant songbird. Ecology 82:2628-2635.

KarR, J. R., AND K. E. Freemark. 1985. Disturbance and vertebrates: An integrative perspective. Pages 153-168 in Natural Disturbance and Patch Dynamics (S. T. A. Pickett and P. S. White, Eds.). Academic Press, Orlando, Florida.

KenWARD, R. 1996. Goshawk adaptation to deforestation: Does Europe differ from North America? Pages 233-243 in Raptors in Human Landscapes (D. M. Bird, D. E. Varland, and J. J. Negro, Eds.). Academic Press, London.

Lens, L., AND A. A. DHONDT. 1992. The effect of a severe storm on a population of Crested Tits $\mathrm{Pa}$ rus cristatus in Belgium. Bird Study 39:31-33.

MÖNKKÖNEN, M., AND D. A. Welsh. 1994. A biogeographical hypothesis on the effects of human caused landscape changes on the forest bird communities of Europe and North America. Annales Zoologica Fennici 31:61-70.

Newton, I., M. Marquiss, D. N. Weir, AND D. Moss. 1977. Spacing of sparrowhawk nesting territories. Journal of Animal Ecology 46:425-441.

Penteriani, V. 2001. The annual and diel cycles of goshawk vocalizations at the nest-site. Journal of Raptor Research 35:24-30.

Penteriani, V. 1999a. Echelles et facteurs de la sélection de l'habitat de nidification: Le cas de l'Autour des palombes Accipiter gentilis. Ph.D. dissertation, Burgundy University, Dijon, France.

PENTERIANI, V. 1999b. Dawn and morning goshawk courtship vocalizations as a method for detecting nest sites. Journal of Wildlife Management 63:511-516.

Penteriani, V., AND B. Faivre. 1997. Breeding density and nest site selection in a goshawk Accipiter gentilis population of the Central Apennines (Abruzzo, Italy). Bird Study 44:136-145.

Penteriani, V., AND B. Faivre. 2001. Effects of timber harvesting on goshawk nesting stands in two European areas. Biological Conservation 101:211-216.

Penteriani, V., B. Faivre, AND B. Frochot. 2001. An approach to identify factors and levels of nesting habitat selection: A cross-scale analysis of goshawk preferences. Ornis Fennica 78:159-167.

Pickett, S. T. A., AND P. S. White, Eds. 1985. The Ecology of Natural Disturbance and Patch Dynamics. Academic Press, Orlando, Florida.

Robinson, S. K., F. R. ThOMPSON III, T. M. DonOVAN, D. R. WhiteheAd, AND J. FAABORG. 1995. Regional forest fragmentation and the nesting success of migratory birds. Science 267:1987-1990.

SOKAL, R. R., AND F. J. ROHLF. 1995. Biometry, 3rd ed. Freeman, New York. 
StArfield, A. M., AND A. L. Bleloch. 1991. Building Models for Conservation and Wildlife Management, 2nd ed. Burgess International Group, Edina, Minnesota.

White, P. S., AND S. T. A. PICKETT. 1985. Natural disturbance and patch dynamics: An introduction.
Pages 3-13 in Natural Disturbance and Patch Dynamics (S. T. A. Pickett and P. S. White, Eds.). Academic Press, Orlando, Florida.

Received 9 October 2001, accepted 8 June 2002. Associate Editor: C. D. Marti

The Auk 119(4):1137-1141, 2002

\title{
Investigation of Interacting Effects of Female Age, Laying Dates, and Egg Size in Yellow-eyed Penguins (Megadyptes antipodes)
}

\author{
Melanie Massaro, ${ }^{1,4}$ John T. Darby, ${ }^{1}$ Lloyd S. Davis,${ }^{1}$ Kerri-Anne Edge, ${ }^{2}$ And Michael J. Hazel ${ }^{3}$ \\ ${ }^{1}$ Department of Zoology, University of Otago, P.O. Box 56, Dunedin, New Zealand; \\ ${ }^{2}$ Department of Conservation, P. O. Box 743, Invercargill, New Zealand; and \\ ${ }^{3}$ Sinclair Wetlands, RD 1, Outram 9055, New Zealand
}

\begin{abstract}
Increased experience with age may allow long-lived seabirds to forage more efficiently and ultimately to invest more into reproduction. In many seabirds, egg size increases with female age, but declines with laying date. Declines in laying date might be due either to quality of individual females or females may adjust their egg size in response to poorer conditions typically found late in the season. We investigated the influence of female age, date of laying, and annual variation on egg size in Yelloweyed Penguins (Megadyptes antipodes). Further, we tested whether there was an effect of individual females or female age on date of laying. Whereas female age influenced egg volume, mass, and width, laying date had no effect on egg size or mass in Yellow-eyed Penguins. Laying dates differed significantly among females but were not affected by their ages. These results indicate that in Yellow-eyed Penguins, some individual females lay consistently early or late, regardless of age, but that egg size generally increases with age.
\end{abstract}

RESUMEN.-La mayor experiencia obtenida con la edad puede permitir a las aves marinas longevas forrajear con mayor eficacia y en última instancia, invertir más en la reproducción. En muchas aves marinas el tamaño de los huevos aumenta con la edad de la hembra, pero disminuye con la fecha de la puesta. La disminución del tamaño con la fecha de la puesta puede deberse a la calidad de cada hembra o a que las hembras pueden ajustar el tamaño del huevo en respuesta a condiciones más pobres típicas de los periodos más tardíos de la estación. Investigamos la influencia de la edad de la hembra, la fecha de puesta y la variación anual sobre el tamaño del

\footnotetext{
${ }^{4}$ E-mail: masme209@student.otago.ac.nz
}

huevo en los pingüinos Megadyptes antipodes. Además, probamos si había un efecto a nivel de cada hembra o de la edad de la hembra sobre la fecha de puesta. Aunque la edad de la hembra influyó sobre el volumen del huevo, la masa, y el ancho, la fecha de puesta no tuvo un efecto sobre el tamaño o masa del huevo en $M$. antipodes. Las fechas de puesta difirieron significativamente entre las hembras pero no fueron afectadas por las edades de éstas. Estos resultados indican que en $M$. antipodes, algunas hembras ponen consistentemente temprana o tardíamente en la temporada, independientemente de su edad, pero que el tamaño del huevo generalmente aumentó con la edad.

Several studies have found interacting effects of female age and laying date on egg and clutch size in seabirds that breed in seasonal environments: egg and clutch size increase with female age, but decline with laying date (e.g. Coulson and White 1958, Nelson 1966, Furness 1983). Two competing hypotheses have been developed to explain declines in clutch and egg size with laying date (Winkler and Allan 1996). Decrease in egg and clutch size might be due either to the quality of individual females, whereby poorer quality females (those less able to devote resources to egg production) lay small eggs as well as clutches late in the season, or females may adapt their clutch size to the poorer conditions typically found late in the season (Birkhead and Nettleship 1982). Although in some species egg and clutch size seem to be driven by laying date (with older females producing small clutches or eggs if they lay late), in other species age affects laying date as well as egg and clutch size, with older females tending to lay earlier and to lay larger eggs and clutches (e.g. Hamman 
TABLE 1. Mean first-egg laying dates in relation to female age for Yellow-eyed Penguins from 1936 until 1954 (Richdale 1957; table 47) and from 1991 until 1997 and 2000.

\begin{tabular}{|c|c|c|c|c|c|c|}
\hline \multirow[b]{2}{*}{$\begin{array}{c}\text { Female age } \\
\text { (years) }\end{array}$} & \multicolumn{3}{|c|}{ Richdale (1957) } & \multicolumn{3}{|c|}{ This study } \\
\hline & $n$ & $\begin{array}{c}\text { Mean } \\
\text { (September) }\end{array}$ & $\begin{array}{l}\text { SD } \\
\text { (days) }\end{array}$ & $n$ & $\begin{array}{c}\text { Mean } \\
\text { (September) }\end{array}$ & $\begin{array}{l}\text { SD } \\
\text { (days) }\end{array}$ \\
\hline 3 & 98 & 21.9 & 5.7 & 9 & 27.6 & 3.3 \\
\hline 4 & 81 & 22.4 & 5.3 & 16 & 28.1 & 4.4 \\
\hline 5 & 66 & 23.1 & 4.4 & 11 & 25.8 & 4.4 \\
\hline 6 & & & & 8 & 27.8 & 3.2 \\
\hline 7 & & & & 14 & 26.6 & 3.6 \\
\hline 8 & & & & 13 & 28.2 & 2.5 \\
\hline 9 & & & & 17 & 26.9 & 4.2 \\
\hline 10 & & & & 9 & 27.2 & 4.0 \\
\hline 11 & & & & 5 & 28.2 & 3.2 \\
\hline 12 & & & & 13 & 29.7 & 4.0 \\
\hline 13 & & & & 6 & 26.5 & 3.5 \\
\hline $6-13$ & 62 & 24.4 & 4.4 & 85 & 27.6 & 3.6 \\
\hline $14+$ & 9 & 27.1 & 5.0 & 23 & 30.0 & 5.1 \\
\hline
\end{tabular}

and Cooke 1989, Croxall et al. 1992, Hipfner et al. 1997).

In Yellow-eyed Penguins (Megadyptes antipodes), Richdale (1957) found that egg length, width, and mass increased with female age, but although female age influenced laying date, females laid later as they grew older (Table 1). However, Richdale (1957) did not test for a possible interacting effect of female age and laying date on egg size in Yellow-eyed Penguins. Additionally, he did not consider annual variation of ecological factors, such as food supply, that might also influence time of laying and egg size (Perrins 1970, Hiom et al. 1991).

We investigated interacting effects of female age, laying date, and egg size in Yellow-eyed Penguins. Using multiway analyses, we simultaneously analyzed influence of female age as well as laying date and annual variation on egg size. Further, we tested whether there was an effect of individual females or female age on dates of laying.

Study area and field methods. - Yellow-eyed Penguins were studied at Boulder Beach on the Otago Peninsula $\left(45^{\circ} 50^{\prime} \mathrm{S}, 170^{\circ} 30^{\prime} \mathrm{E}\right)$, situated on the southeastern coast of the South Island of New Zealand from 1991 until 1997 and in 2000. Generally, females lay two similarly sized eggs three to five days apart in September and October (Richdale 1957, Darby and Seddon 1990). Nests were checked regularly for newly laid eggs every two to four days in 1992 and 1993, and every day in 2000. In 1992 and 2000, newly laid eggs were measured immediately (length and width) to $0.1 \mathrm{~mm}$, weighed to the nearest $1 \mathrm{~g}$, and marked as " $\mathrm{A}$ " or " $\mathrm{B}$ " eggs. If eggs were laid in between visits, the date midway between two visits (rounded up) was taken as the date of laying. In 1993, eggs were measured but not marked or weighed. A total of 55 A eggs, 47 B eggs, and eggs of 33 clutches were measured, where laying order was unknown. Eight
A eggs were from one-egg clutches, usually produced by first-time breeders (commonly two or three years of age) and rarely by females over three years of age (Richdale 1957). We calculated clutch volume by summing egg volume (length $\times$ width$^{2}$; Warham 1975) of A and B eggs. In 1991, 1994, 1995, 1996, and 1997, nests were checked regularly for eggs every two to four days. In those seasons, laying dates of eggs were recorded, but no eggs were measured. In all years, band numbers were recorded for all laying females. Due to long term monitoring of Yellow-eyed Penguins since 1980, all birds included in this study were individually marked and their sex was known when the study began. Most penguins were banded as chicks or juveniles (one-year old prebreeders that can be distinguished from breeding adults by plumage) and their exact ages were known. However, a few penguins were banded as adults and we calculated their minimum age by assuming they were at least three years old when they were first banded.

Statistical analyses.-Prior to any analyses that included laying date as an independent variable, we controlled for year effects on date of laying by calculating separately mean laying dates for A and B eggs each year and classifying laying dates as early (laid two or more days before mean laying), mean (laid on the mean laying date \pm 1 day), or late (laid two or more days after mean laying).

We used a multiway ANCOVA with female age as a covariate to test whether female age, laying date, year, or any of the first-order interactions increased clutch volume. Nonsignificant interaction terms were removed from the analysis. Only two-egg clutches were included in this analysis.

Separate analyses (multiway ANCOVA) were performed on A and B eggs to test whether egg volume, mass, length, or width were influenced by female age, laying date, year, or any of the first-order inter- 


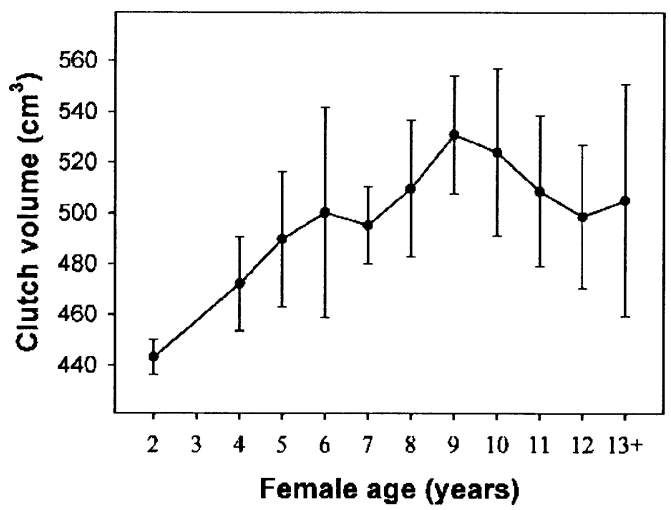

FIG. 1. Mean clutch volume (sum of A and B egg volume; $\pm 1 \mathrm{SD}$ ) of Yellow-eyed Penguin nests in relation to female age $(n=80)$ in 1992, 1993, and 2000 . Only two-egg clutches are included. The increase in clutch volume in 2 to 9 year old females was significant, whereas the decrease in clutch volume in 9 to 17 year-old females was not significant.

actions. Nonsignificant interaction terms were again removed from the analyses.

For analysis of factors influencing date of laying, clutches were used where date of laying of the first egg was known with an accuracy of at least \pm 2 days. Mean first-egg laying dates were determined for each year from 1991 to 1997 and for 2000. To control for variability in date of laying among years, we calculated differences in days between mean laying and date of laying of first eggs of individual clutches. Negative values indicate individual clutches were initiated before mean laying and positive values represent clutch initiation after mean laying. In the analysis, only females were included that had clutch initiation dates for at least three years. To test whether female age or individual females influenced date of laying, an ANCOVA without interactions was used.

All means are reported \pm 1 SD and the tolerance for Type I error was set at 0.05 for all statistical tests. DATA DESK (Data Description 1995) was used for all statistical analyses.

Results. - Clutch volume increased until females reached an age of nine years and then slowly decreased (Fig. 1). To test for a linear change in clutch volume with age, separate analyses were done for two to nine year-old females and 9 to 17 year-old females. Clutch volume of two-egg clutches increased significantly with increasing age in two to nine yearold females $(F=21.9, \mathrm{df}=1$ and $44, P<0.001)$. Laying date and year did not influence clutch volume in two to nine year-old females $(F=0.1-7.5, \mathrm{df}=2$ and 44, NS). Clutch volume did not decrease significantly with increasing age in 9 to 17 year-old females $(F=$ $1.0, \mathrm{df}=1$ and $28, \mathrm{NS})$, but it varied significantly between the two years $(F=3.3, \mathrm{df}=2$ and $28, P<0.05)$.

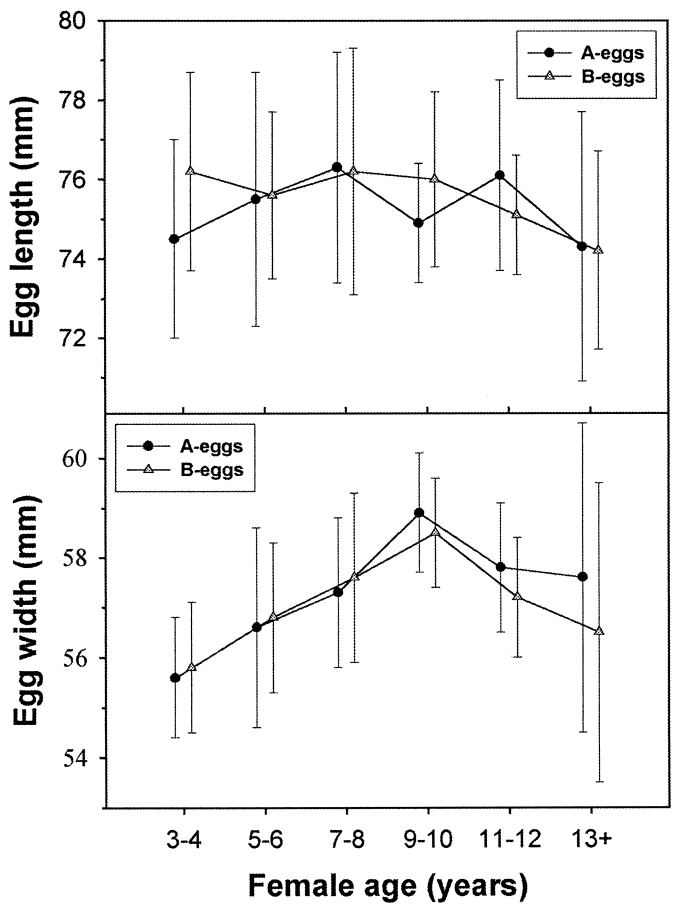

FIG. 2. Mean egg length and egg width $( \pm S D)$ of A eggs $(n=55)$ and B eggs $(n=47)$ of Yellow-eyed Penguins in relation to female age in 1992 and 2000. The sample of A eggs included eight eggs from oneegg clutches and 47 eggs of two-egg clutches.

Mean clutch volume of two-egg clutches was $484 \mathrm{~cm}^{3}$ $( \pm 33)$ in $1992,503 \mathrm{~cm}^{3}( \pm 30)$ in 1993 , and $503 \mathrm{~cm}^{3}$ $( \pm 34)$ in 2000 .

Egg volume, mass, and width (Fig. 2) of A and B eggs increased until females reached an age of nine years and then decreased slightly. To test for a linear change in egg volume, mass, length, and width with age, separate analyses were done for 2 to 9 year-old females and 9 to 17 year-old females. Egg volume, mass, and width of A and B eggs increased significantly with age in two to nine year-old females (A egg: $F=10.8-15.1, \mathrm{df}=1$ and $34, P<0.01$; $\mathrm{B}$ egg: $F$ $=7.3-9.4$, df $=1$ and 26, $P<0.02)$. Egg length of $\mathrm{A}$ and $\mathrm{B}$ eggs did not increase significantly with age in two to nine year-old females (Fig. 2). In 9 to 17 yearold females, width of A eggs and egg volume, mass, and width of $B$ eggs varied significantly between years (A egg: $F=6.5$, df $=1$ and $13, P<0.05$; $B$ egg: $F=8.6-11.2, \mathrm{df}=1$ and $13, P<0.02)$, but was not influenced by female age.

Clutch initiation dates were related to the identity of females, but not to female age (female: $F=2.5$, df $=34$ and 108, $P<0.001$; age: $F=2.8, \mathrm{df}=1$ and 108, NS). Mean laying dates for differently aged females are shown in Table 1. 
Discussion.-Although female age influenced egg volume, mass, and width, laying date had no effect on egg size or mass in Yellow-eyed Penguins. Neither egg- nor clutch-size decline with laying date was found as reported in other seabirds (e.g. Black-legged Kittiwake [Rissa tridactyla], Coulson and White 1958; Northern Gannet [Sula bassanus], Nelson 1966; Thick-billed Murres [Uria lomvia], Birkhead and Nettleship 1982, Gaston et al. 1994). In contrast to most other seabirds, Yellow-eyed Penguins are yearround residents at their breeding grounds and feed mainly on demersal fish (Richdale 1957, Van Heezik 1990). Their food resources probably do not decline as rapidly towards the end of the season as they do for other seabirds breeding in temperate or high latitudes where food availability is highly seasonal. For Yellow-eyed Penguins, it may not be advantageous to lay early in the season. In fact, Richdale (1957) found that females that invested most in egg production (6 to 13 years old) laid later than younger females. In this study, nine year-old females laid the largest eggs; however, in contrast to Richdale's results, those females did not lay later than younger females. Individual females laid at the same time relative to mean laying date irrespective of their ages. In Thickbilled Murres, Hipfner et al. (1997) showed a strong correlation between laying dates in two subsequent seasons by old females, but not in young females. However, female murres also laid earlier as they increased in age up to eight years old (Gaston et al. 1994). It is not apparent from Hipfner et al.'s (1997) study whether individual effects, female age, or both influenced date of laying. Our results demonstrate that in Yellow-eyed Penguins, timing of laying is related to the differences between individual females and not their ages.

Whereas Richdale (1957) maintained that females increased investment in egg size up to 13 years of age, in this study females over 9 years old tended to lower their investment in egg production, although not significantly. The exceptions were two females (14 and 17 years) that laid two of the largest clutches in 2000, despite their old age. However, one egg of the 14 year old and the complete clutch of the 17 year old failed to hatch. Those were the only two females in our sample that were over 13 years old. We were therefore unable to test whether egg size decreased in females over 13 years old, as Richdale (1957) described, but certainly the large size of their eggs was not consistent with Richdale's observations. Declines in clutch or egg volume in old seabirds have been reported for Western Gulls (Larus occidentalis) over 13 years old (Sydeman and Emslie 1992) and Herring Gulls (L. argentatus) over 8 years old (Davis 1975). Declines in clutch or egg volume in older birds could be due to senescence and the deterioration of physiological and foraging capacities or it could be related to the possibility that individual females that in- vest less energy in reproduction live longer than those that invest more (Sæther 1990).

Acknowledgments.-We thank A. Setiawan, S. Neumann, and all the volunteers that helped during eight years of data collection on Yellow-eyed Penguins breeding at Boulder Beach. We thank the Yellow-eyed Penguin Trust for financial, logistical, and moral support. We are grateful to I. Jamieson, J. Quinn, and S. Waugh for looking at earlier drafts of the manuscript. This study would not have been possible without permits and support from the Department of Conservation, in particular D. Nelson, B. McKinlay and D. Houston. This work was carried out under the auspices of a University of Otago Animal Ethics Committee permit. The study was supported by grants from the Yellow-eyed Penguin Trust, the Department of Conservation, a University of Otago Postgraduate Scholarship to M.M. and an Otago Research Grant to L.S.D.

\section{Literature Cited}

BirkheAd, T. R., AND D. N. NetTleship. 1982. The adaptive significance of egg size and laying date in Thick-billed Murres Uria lomvia. Ecology 63: 300-306.

Coulson, J. C., AND E. White. 1958. The effect of age on the breeding biology of the Kittiwake Rissa tridactyla. Ibis 100:40-51.

Croxall, J. P., P. Rothery, And A. Crisp. 1992. The effect of maternal age and experience on eggsize and hatching success in Wandering Albatrosses Diomedea exulans. Ibis 134:219-228.

DARby, J. T., AND P. J. Seddon. 1990. Breeding biology of Yellow-eyed Penguin Megadyptes antipodes. Pages 45-62 in Penguin Biology (L. S. Davis and J. T. Darby, Eds.). Academic Press, San Diego, California.

Data Description. 1995. Data Desk User's Guide, version 5.0. Data Description Inc., Ithaca, New York.

DAVIS, J. W. F. 1975. Age, egg size and breeding success in the Herring Gull Larus argentatus. Ibis 117:460-472.

FURNESS, R. W. 1983. Variation in size and growth of Great Skua Catharacta skua chicks in relation to adult age, hatching date, egg volume, brood size, and hatching sequence. Journal of Zoology (London) 199:101-116.

Gaston, A. J., L. N. DE Forest, G. Donaldson, AND D. G. Noble. 1994. Population parameters of Thick-billed Murres at Coats Island, Northwest Territories, Canada. Condor 96:935-948.

HAMMAN, J., AND F. COOKE. 1989. Intra seasonal decline in clutch size in Lesser Snow Geese. Oecologica 79:83-90.

Hiom, L., M. Bolton, P. Monaghan, And D. WoRRALL. 1991. Experimental evidence for food 
limitation of egg production in gulls. Ornis Scandinavica 22:94-97.

Hipfner, J. M., A. J. Gaston, And L. N. DE Forest. 1997. The role of female age in determining egg size and laying date of Thick-billed Murres. Journal of Avian Biology 28:271-278.

Nelson, J. B. 1966. The breeding biology of the Gannet Sula bassanus on the Bass Rock, Scotland. Ibis 108:584-626.

PERrins, C. M. 1970. The timing of birds' breeding seasons. Ibis 112:242-255.

Richdale, L. E. 1957. A Population Study of Penguins. Oxford University Press, Oxford.

SæTHER, B.-E. 1990. Age-specific variation in reproductive performance of birds. Current Ornithology 7:251-283.

SYDEMAN, W. J., AND S. D. EMSLIE. 1992. Effects of parental age on hatching asynchrony, egg size and third-chick disadvantage in Western Gulls. Auk 109:242-248.

VAN HeEZIK, Y. 1990. Diets of Yellow-eyed, Fiordland Crested, and Little Blue penguins breeding sympatrically on Codfish Island, New Zealand. New Zealand Journal of Zoology 17:543-548.

Warham, J. 1975. The Crested Penguins. Pages 189269 in The Biology of Penguins (B. Stonehouse, Ed.). MacMillan, London.

WinkLER, D. W., AND P. E. AlLEN. 1996. The seasonal decline in Tree Swallow clutch size: Physiological constraint or strategic adjustment? Ecology 77:922-932.

Received 14 June 2001, accepted 15 July 2002.

Associate Editor: D. N. Nettleship

The Auk 119(4):1141-1149, 2002

\title{
Complex Vocalizations and Aerial Displays of the Amethyst-throated Hummingbird (Lampornis amethystinus)
}

\author{
Juan Francisco Ornelas, ${ }^{1,2}$ Clementina GonzÁlez, ${ }^{1}$ And Jorge Uribe ${ }^{1,3}$ \\ ${ }^{1}$ Departamento de Ecología y Comportamiento Animal, Instituto de Ecología, AC, Apartado Postal 63, Xalapa, \\ Veracruz 91070, México
}

\begin{abstract}
Long considered to utter only simple calls, hummingbirds are now known to produce songs distinct from calls. Some species have complex songs, but their acoustic characteristics, structure and organization, function, and the evolution of vocal repertoires are not completely known. Here, we describe the aerial display and most common vocalizations of Amethyst-throated Hummingbird (Lampornis amethystinus) under different behavioral contexts, during its breeding season in western Mexico. We identified four types of vocalizations: (1) a territorial call, produced mainly by males often in response to another neighbor's chattering, when leaving his territory, and during chases; (2) feeding call, given mostly while foraging; (3) display call, a series of descendent frequency whistle notes, given while performing aerial displays; and (4) song, composed of an introductory phrase and a mixture of notes arranged into four to nine complex phrases, covering a wide frequency range. Our observations of horizontal aerial displays are the first for Amethyst-
\end{abstract}

\footnotetext{
2 E-mail: ornelasj@ecologia.edu.mx

${ }^{3}$ Present address: Department of Biology, University of Missouri-St. Louis, 8001 Natural Bridge Road, St. Louis, Missouri 63121-4499, USA.
}

throated Hummingbirds. Comparisons with L. amethystinus congeners indicated similarities in song complexity. Our results supported the hypothesis that the evolution of diverse acoustic signals may be favored, independently of habitat characteristics, by the complex foraging interactions that hummingbirds experience every day as they need to communicate intra- and interspecifically.

RESUMEN.-Los colibríes habían sido considerados como aves que emiten llamados simples. Sin embargo, hoy en día se sabe que producen cantos que difieren de los llamados. Algunas especies tienen cantos complejos, pero sus características acústicas, estructura, organización, función y evolución de repertorios vocales son poco conocidos. En este trabajo describimos el despliegue aéreo y las vocalizaciones más comunes del colibrí garganta amatista (Lampornis amethystinus) bajo diferentes contextos de comportamiento, durante la época reproductiva en el oeste de México. Identificamos cuatro tipos de vocalizaciones: (1) llamado territorial, producido principalmente por machos en respuesta al llamado de algún vecino, cuando abandona su territorio y durante enfrentamientos agresivos, (2) llamado de alimentación, el cual ocurre la mayoría de las veces 
mientras forrajean, (3) llamado de despliegue, que incluye una serie de silbidos de frecuencia descendente, emitidos durante los despliegues aéreos, y (4) canto, compuesto por una frase introductoria y una mezcla de notas arregladas en 4-9 frases complejas de amplio rango de frecuencia. Nuestras observaciones de despliegues aéreos horizontales son las primeras para el colibrí garganta amatista. Las comparaciones entre congéneres indicaron similitud en la complejidad del canto. Nuestros resultados sustentan la hipótesis de que la evolución de señales acústicas diversas están más favorecidas, independientemente de las características del hábitat, por las complejas interacciones de forrajeo que los colibríes experimentan cada día ya que necesitan comunicarse intra e interespecíficamente.

Hummingbirds offer many opportunities for studying the function and variation in song advertisement. Males, and in some species, females vocalize in several different contexts (Wiley 1971, Gaunt et al. 1994, Ficken et al. 2000), but the acoustic characteristics, structure and organization, function, and the evolution of vocal display repertoires in hummingbirds are largely unknown (Kroodsma et al. 1996). Knowledge of the context in which birds sing is important because it can provide valuable clues as to the possible functions of song (Catchpole and Slater 1995). Despite this, the behavioral variation in aerial and vocal displays among hummingbirds has been infrequently studied. For a long time, hummingbirds were believed to have relatively simple calls or songs (Johnsgard 1997); however, it is now known that they produce songs distinct from calls (Baptista 1996) and some species have complex songs (Ficken et al. 2000). Ficken et al. (2000) documented the complexity, organization, and function of song of Blue-throated Hummingbird (Lampornis clemenciae), and hypothesized that complex songs are likely to evolve among hummingbirds that inhabit dense vegetation.

Here, we present spectrograms of the most common vocalizations of the poorly known Amethystthroated Hummingbird (L. amethystinus) to demonstrate that vocalizations change with respect to the social context of the displayer, and describe the aerial display during its breeding season in western Mexico. Then we compare song complexity of this hummingbird species with congeners and other hummingbird species to elucidate patterns of song complexity in this genus, and to test Ficken et al.'s (2000) hypothesis.

Methods.-Field observations and recordings were conducted at Las Joyas field station $\left(19^{\circ} 35^{\prime}-19^{\circ} 37^{\prime} \mathrm{N}\right.$; $103^{\circ} 15^{\prime}-104^{\circ} 37^{\prime} \mathrm{W}$; at $1,952 \mathrm{~m}$ above sea level; Lara and Ornelas 2001). That 1,245 ha preserve is located at the Sierra de Manantlán Biosphere Reserve in the Mexican states of Jalisco and Colima. Las Joyas is a mosaic of pine-oak woodlands, fragments of cloud forest along ravines, and second-growth vegetation. A detailed description of the study area is given in Lara and Ornelas (2001).

Our study focused on one of the 21 hummingbird species recorded at Las Joyas, the Amethyst-throated Hummingbird, which breed in the mountains of western Mexico from Nayarit, Jalisco, San Luis Potosí, and South Tamaulipas to El Salvador, and Honduras (Howell and Webb 1995). Amethyst-throated Hummingbirds are permanent residents and breed from June to September. During that time, they feed mostly from flowers of Ipomoea hederifolia (Convolvulaceae) and Crusea coccinea (Rubiaceae) (J. F. Ornelas unpub. data). Amethyst-throated Hummingbirds are commonly found inside patches of cloud forest, but during the breeding season males can be seen in more open areas. Males aerially display, vocalize, and aggressively defend floral patches of $I$. hederifolia (Lara and Ornelas 2001). The species is sexually dichromatic and, hence, the sexes were readily distinguished in the field.

Vocalizations were recorded from July through August using a Sennheiser ME 80 shotgun microphone and a Sony TCM-5000 EV tape recorder. Twenty-one males were recorded in the 1991 and 1992 breeding seasons under different behavioral contexts, including perching on a twig, while foraging, preceding and during aerial displays, and during territorial chases. Males were not individually marked, but birds were recorded in different areas of the preserve in both years. Recordings were made from 3-10 $\mathrm{m}$ distance of the focal individuals. Original recordings and edited vocalizations are deposited in our collection at the Laboratorio de Bioacústica, Instituto de Ecología AC, Xalapa (LABIEXAL). We also used recordings of Amethyst-throated Hummingbird's congeners the Blue-throated Hummingbird and Green-throated Mountain-gem (L. viridipallens), and Magnificent Hummingbird (Eugenes fulgens) from other archives (see Appendix) to make comparisons of song structure and complexity.

Sonograms were then made with CANARY 1.2.1 (Charif et al. 1995) in a Power MacIntosh 8,500/150 computer. Sampling rate was set at $44,100 \mathrm{~Hz}$ and a 349.7 Hz filter bandwidth and a 512-frame length resolution made all spectrograms. On each spectrogram was measured duration of song and calls, duration of notes, maximum and minimum frequencies, bandwidth (bandwidth $=$ max frequency - min frequency), duration and frequencies of the introductory phrase (song), phrases per song, and duration of silent intervals between notes or syllables. We calculated the mean of the variables measured for each recording and then computed the mean of the means to represent the entire sample (see Table 1). Vocalizations of congeners were termed "songs" because of their structural complexity and organization (Ficken et al. 2000). 
TABLE 1. Descriptive statistics for acoustics variables of the four different vocalizations of L. amethystinus at Manantlán, México. Numbers are mean \pm SE (range), $n_{1}=$ number of recordings, $n_{2}=$ number of notes analyzed. Individual notes were not measured for male songs.

\begin{tabular}{|c|c|c|c|c|}
\hline Variable & $\begin{array}{c}\text { Territorial call } \\
\quad\left(n_{1}=5\right. \\
\left.n_{2}=202\right)\end{array}$ & $\begin{array}{l}\text { Feeding call } \\
\quad\left(n_{1}=5 ;\right. \\
\left.n_{2}=205\right)\end{array}$ & $\begin{array}{c}\text { Display call } \\
\left(n_{1}=6 ;\right. \\
\left.n_{2}=48\right)\end{array}$ & $\begin{array}{c}\text { Song } \\
\left(n_{1}=14\right)\end{array}$ \\
\hline Total duration (s) & $\begin{array}{c}101.16 \pm 43.29 \\
(22.37-269)\end{array}$ & $\begin{array}{l}5.48 \pm 2.32 \\
(0.86-12.83)\end{array}$ & $\begin{array}{l}5.44 \pm 0.67 \\
(2.76-7.21)\end{array}$ & $\begin{array}{l}5.59 \pm 0.32 \\
(3.55-7.42)\end{array}$ \\
\hline $\begin{array}{l}\text { Duration of the introductory } \\
\text { phrase (s) }\end{array}$ & - & - & - & $\begin{array}{l}0.17 \pm 0.002 \\
(0.16-0.18)\end{array}$ \\
\hline Duration of notes (s) & $\begin{array}{l}0.02 \pm 0.002 \\
(0.0015-0.03)\end{array}$ & $\begin{array}{l}0.017 \pm 0.004 \\
(0.012-0.035)\end{array}$ & $\begin{array}{l}0.16 \pm 0.003 \\
(0.12-0.2)\end{array}$ & - \\
\hline Duration of silent intervals (s) & $\begin{array}{r}0.35 \pm 0.08 \\
(0.185-0.63)\end{array}$ & $\begin{array}{l}0.48 \pm 0.16 \\
(0.145-1.0)\end{array}$ & $\begin{array}{r}0.59 \pm 0.02 \\
(0.5-0.62)\end{array}$ & - \\
\hline Maximum frequency $(\mathrm{kHz})$ & $\begin{array}{l}7.32 \pm 0.19 \\
(6.89-7.9)\end{array}$ & $\begin{array}{c}10.64 \pm 0.14 \\
(10.2-11.02)\end{array}$ & $\begin{array}{r}7.69 \pm 0.13 \\
(7.15-8.06)\end{array}$ & $\begin{array}{c}10.28 \pm 0.11 \\
(9.38-11.01)\end{array}$ \\
\hline $\begin{array}{l}\text { Maximum frequency of the introduc- } \\
\text { tory phrase }(\mathrm{kHz})\end{array}$ & - & - & - & $\begin{array}{l}10.69 \pm 0.07 \\
(10.29-11.1)\end{array}$ \\
\hline Minimum frequency $(\mathrm{kHz})$ & $\begin{array}{l}3.86 \pm 0.12 \\
(3.59-4.25)\end{array}$ & $\begin{array}{l}2.38 \pm 0.17 \\
(1.8-2.8)\end{array}$ & $\begin{array}{l}6.26 \pm 0.29 \\
(5.67-7.7)\end{array}$ & $\begin{array}{c}0.884 \pm 0.04 \\
(0.73-1.09)\end{array}$ \\
\hline $\begin{array}{l}\text { Minimum frequency of the introduc- } \\
\text { tory phrase }(\mathrm{kHz})\end{array}$ & - & - & - & $\begin{array}{l}2.39 \pm 0.1 \\
(1.55-2.82)\end{array}$ \\
\hline Bandwidth $(\mathrm{kHz})$ & $\begin{array}{l}3.47 \pm 0.24 \\
\quad(2.7-4.2)\end{array}$ & $\begin{array}{l}8.26 \pm 0.24 \\
(7.42-8.96)\end{array}$ & $\begin{array}{l}1.73 \pm 0.09 \\
(1.45-2.06)\end{array}$ & $\begin{array}{l}9.77 \pm 0.08 \\
(9.33-10.37)\end{array}$ \\
\hline Phrases per song & - & - & - & $\begin{array}{c}6.78 \pm 0.38 \\
(4-9)\end{array}$ \\
\hline Behavioral context & $\begin{array}{l}\text { As a male re- } \\
\text { sponse to an- } \\
\text { other neighbor's } \\
\text { chattering, } \\
\text { when leaving } \\
\text { his territory, } \\
\text { and during } \\
\text { chases }\end{array}$ & $\begin{array}{l}\text { Given mostly } \\
\text { while foraging }\end{array}$ & $\begin{array}{l}\text { Given while } \\
\text { performing } \\
\text { the aerial dis- } \\
\text { play }\end{array}$ & $\begin{array}{l}\text { Given when } \\
\text { males were } \\
\text { perched on ex- } \\
\text { posed twigs at } \\
\text { different } \\
\text { heights in } \\
\text { open areas }\end{array}$ \\
\hline
\end{tabular}

Results.-Amethyst-throated Hummingbird males vocalized mainly from exposed perches as they turned their heads, displaying their brilliant amethyst gorgets. Singing was more prevalent early in the morning, with a second peak in the evening, as observed for Blue-throated Hummingbirds (Ficken et al. 2000). Four types of vocalizations emitted by males were identified during our study. The acoustic characteristics and the contexts are presented in Table 1 .

Territorial call is a chattering sound composed of single, one-type notes with short duration (Fig. 1A). Howell and Webb (1995) presumably described this call as a rapid, fairly hard, clicking " $k i-k i-k i-k i-k i k$ $k i-k i k$. ." The number of " $k i k$ " notes produced in every territorial call was highly variable (Table 1). We observed no females defending territories or vocalizing.

Feeding call is a buzzy "tzzzzir" according to Howell and Webb (1995). It consisted of a series of notes grouped most of the time into buzzy elements of two up to eight notes. Sometimes, Amethyst-throated Hummingbirds emitted a few single notes after a se- ries of buzzes (Fig. 1B). The duration of this call was also highly variable (Table 1 ).

Display call is a series of descendent frequency whistle notes (Fig. 1C). Howell and Webb (1995) described a similar call as ". . . a high, slightly shrill siik in flight ". While aerially displaying, males uttered 7-10 single-note calls. In general, the frequency of notes increased over time and decreased slightly by the last note, but not the duration of each note (Table 1 ). The duration of silent intervals also decreased a little over time, and this call had the lowest bandwidth of all Amethyst-throated Hummingbird's vocalizations.

Five individual males displayed the following stereotyped behavior on several consecutive days, especially in the evening. Males were perched on exposed twigs 1-3 $\mathrm{m}$ high, uttering a series of low-pitched, warbled notes lasting $>5 \mathrm{~s}$ (song). This series of notes ended as males started climbing out from the perch to initiate the aerial display. Males then traced in a plane parallel to the ground, almost horizontally, a circle of varying diameter $(\sim 30 \mathrm{~m})$ up to about $10-20 \mathrm{~m}$ above the ground and then plum- 


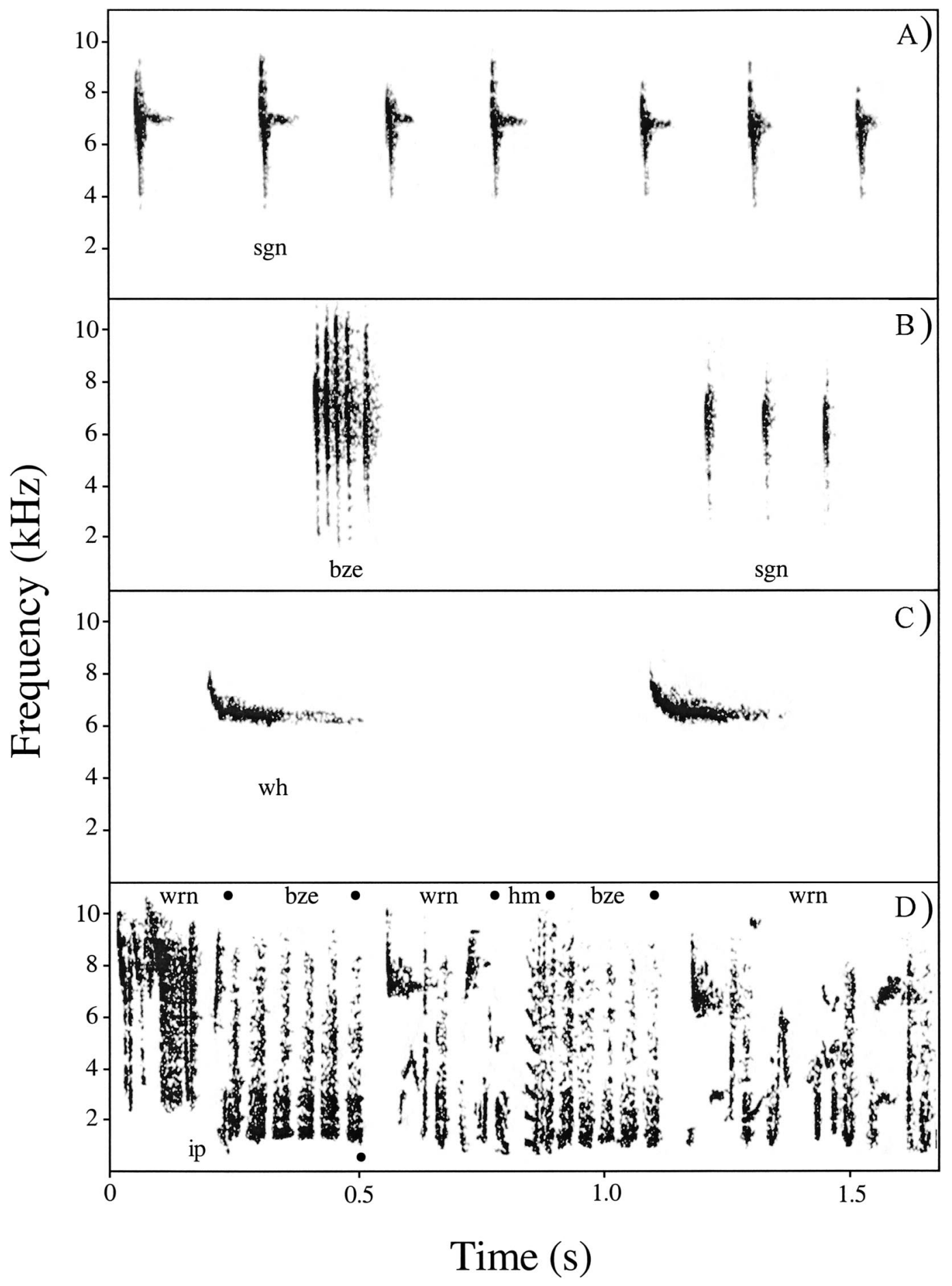

FIG. 1. Vocal repertoire of Amethyst-throated Hummingbird (L. amethystinus) at Manantlán, Jalisco, México under different behavioral contexts: (A) territorial call, (B) feeding call, (C) display call, and (D) male song. Abbreviations indicate the type of note or syllable: $\operatorname{sgn}=$ single notes; bze = buzzy elements; $\mathrm{wh}=$ whistle; ip = introductory phrase; $\mathrm{wrn}=$ warbling notes; $\mathrm{hm}=$ harmonics. 


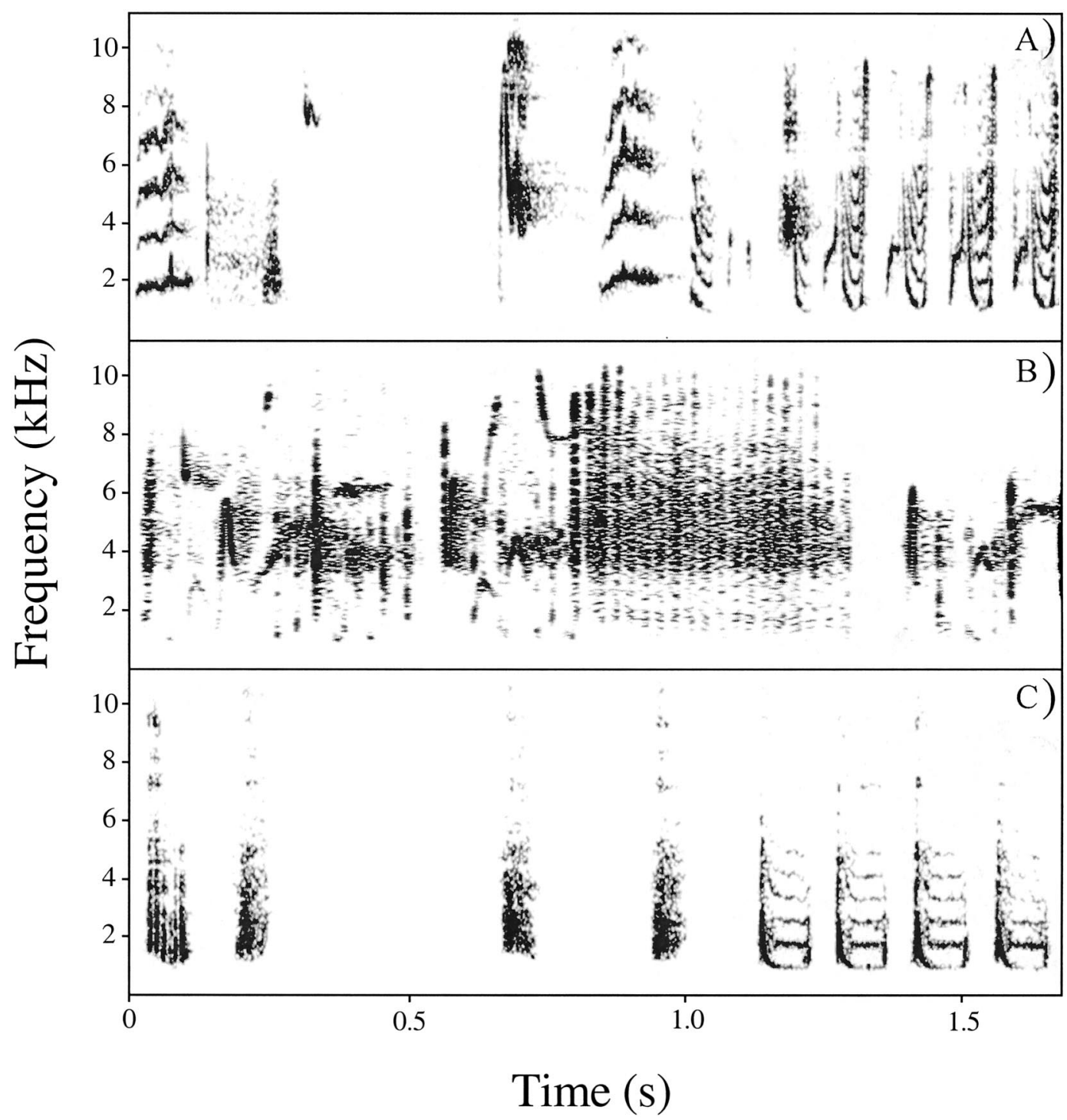

FIG. 2. Songs of Amethyst-throated Hummingbird's congeners: (A) L. viridipallens, (B) L. clemenciae, and (C) E. fulgens.

meted in a dive towards a female before returning to the perch. This circular flight lasts $\sim 15 \mathrm{~s}$ and it is repeated five or six times. While flying, males uttered 7-10 single notes (the "siik" notes described above; Fig. 1C), but upon perching they resumed singing (Fig. 1D).

Males sang while perched on exposed twigs at different heights in open areas. The song is a quiet, dry gurgling chatter lasting $\sim 6 \mathrm{~s}$ composed of an introductory phrase with two syllables. The first syllable is composed of warbling notes, and 6-20 buzzy elements constitute the second one. The song continues with four to nine complex phrases composed of a mixture of notes, including harmonics, covering a wide frequency range (warbling notes) that varies in length, and 6-7 buzzy elements (Fig. 1D). The duration of the introductory phrase was $<1$ s and the frequency was higher than the rest of the song (Table 1). Compared with other Amethyst-throated Hummingbird vocalizations, the song had the lowest minimum frequency and the highest bandwidth (Table 1).

The song of Green-throated Mountain-gem is composed by several syllable types arranged into phrases with frequency modulations (Fig. 2A). Songs of Blue-throated Hummingbirds are also complex; 
TABLE 2. Ecological, morphological, and behavioral correlates with song complexity among hummingbirds. Song complexity was measured as the syllable-type versatility index $=(S \times T) / N$, where $S$ is the number of syllable types per song, $T$ is the number of transitions from one type to another, and $N$ is the total number of syllables per song.

\begin{tabular}{|c|c|c|c|c|c|c|c|}
\hline Species & $\begin{array}{l}\text { Plum- } \\
\text { age }\end{array}$ & Habitat & Resource use & $\begin{array}{l}\text { De- } \\
\text { gree } \\
\text { of } \\
\text { social- } \\
\text { ity }\end{array}$ & $\begin{array}{l}\text { Sing- } \\
\text { ing } \\
\text { assem- } \\
\text { blies }\end{array}$ & $\begin{array}{l}\text { Syllable- } \\
\text { type } \\
\text { versatili- } \\
\text { ty index }\end{array}$ & $\begin{array}{l}\text { Body } \\
\text { mass } \\
(g)\end{array}$ \\
\hline Glaucis hirsuta & M & $\begin{array}{l}\text { Forest and dense } \\
\text { vegetation (1) }\end{array}$ & Trapliner? & 1 & No & $1.44(1)$ & 7.5 \\
\hline Campylopterus curvipennis & M & $\begin{array}{l}\text { Edges of humid for- } \\
\text { est, open wood- } \\
\text { lands (2) }\end{array}$ & Territorial & 2 & Yes & $6.74(3)$ & 12.7 \\
\hline Campylopterus hemileucurus & $\mathrm{D}$ & $\begin{array}{l}\text { Edges of humid for- } \\
\text { est, open wood- } \\
\text { lands (2) }\end{array}$ & $\begin{array}{l}\text { Male territori- } \\
\text { ality }\end{array}$ & 2 & Yes & $5.72(3)$ & 11.8 \\
\hline Aphantochroa cirrhochloris & M & $\begin{array}{l}\text { Edges of humid for- } \\
\text { est, open wood- } \\
\text { lands (2) }\end{array}$ & $?$ & $?$ & $?$ & $4.72(3)$ & 9 \\
\hline Colibri thalassinus & M & $\begin{array}{l}\text { Open shrublands, } \\
\text { highland pastures } \\
\text { with scattered } \\
\text { trees }(2)\end{array}$ & Territorial & 2 & Yes & $0.99(1)$ & 5.7 \\
\hline Cyanthus latirostris & $\mathrm{D}$ & $\begin{array}{l}\text { Open areas with } \\
\text { some trees, arid to } \\
\text { semiarid bushy } \\
\text { woodland (3) }\end{array}$ & $\begin{array}{l}\text { Male territori- } \\
\text { ality }\end{array}$ & 2 & No & $1.03(1)$ & 3.7 \\
\hline Amazilia amazilia & M & $\begin{array}{l}\text { Open areas, semiarid } \\
\text { with shrub, thorn } \\
\text { forest (3) }\end{array}$ & $\begin{array}{l}\text { Interspecific } \\
\text { territoriality }\end{array}$ & $?$ & No & $0.35(1)$ & 4.3 \\
\hline Amazilia versicolor & M & $\begin{array}{l}\text { Edges of cloud and } \\
\text { rain forest (1) }\end{array}$ & $?$ & $?$ & No & $0.03(1)$ & 4 \\
\hline Amazilia franciae & M & Open arid areas (3) & Trapliner & 3 & $?$ & $2.50(2)$ & 5 \\
\hline Amazilia candida & M & $\begin{array}{l}\text { Rain forest and cloud } \\
\text { forest (1) }\end{array}$ & Trapliner & 3 & Yes & $0.69(1)$ & 3.8 \\
\hline Amazilia amabilis & $\mathrm{D}$ & Open woodlands (3) & $\begin{array}{l}\text { Territorial and } \\
\text { trapliner }\end{array}$ & 2 & Yes & $2.37(2)$ & 4.2 \\
\hline Amazilia decora & $\mathrm{D}$ & Open woodlands (3) & $\begin{array}{l}\text { Territorial and } \\
\text { trapliner }\end{array}$ & 1 & Yes & $2.14(2)$ & 4.7 \\
\hline Lampornis clemenciae & $\mathrm{D}$ & $\begin{array}{l}\text { From open to ripari- } \\
\text { an habitats (2) }\end{array}$ & Territorial & 1 & No & $4.16(3)$ & 8 \\
\hline Lampornis amethystinus & $\mathrm{D}$ & Cloud forest (1) & Trapliner & 1 & No & $4.37(3)$ & 5.8 \\
\hline Lampornis viridipallens & $\mathrm{D}$ & Cloud forest (1) & $?$ & $?$ & No & $4.09(3)$ & 5.5 \\
\hline Eugenes fulgens & $\mathrm{D}$ & $\begin{array}{l}\text { From open to ripari- } \\
\text { an habitats (2) }\end{array}$ & $\begin{array}{l}\text { Territorial and } \\
\text { trapliner }\end{array}$ & 1 & No & $2.09(2)$ & 10 \\
\hline Calypte anna & $\mathrm{D}$ & Open woodlands (3) & $\begin{array}{l}\text { Male territori- } \\
\text { ality }\end{array}$ & $?$ & No & $2.25(2)$ & 4.2 \\
\hline
\end{tabular}

Plumage dimorphism $(\mathrm{M}=$ monochromatic, $\mathrm{D}=$ dichromatic $)$, habitat $(1=$ dense vegetation, $2=$ moderately dense vegetation, $3=$ open country), degree of sociality $(1=$ solitary, $2=$ gregarious, $3=$ gathers in large numbers $)$, song complexity $(1=$ simple, $2=$ medium, $3=$ complex). Data on habitat, resource use, and body mass were taken from Schuchmann (1999).

notes are varied in acoustic structure within many transients and trills, but lacking pure tones (Ficken et al. 2000; Fig. 2B). In contrast, fewer syllable types and no frequency modulations (Table 2, Fig. 2C) constitute the song of E. fulgens.

Discussion.-Sexual selection plays an important role in the evolution of oscine song (Catchpole and Slater 1995). In hummingbirds, attention has been focused almost exclusively on visual signals because many species display various ornaments and perform complex aerial displays (Wagner 1954). Dive displays are well known among the "flame-throated" hummingbirds including Archilochus, Calypte, Stellula, Calothorax, Selasphorus, Acestrura, and Mellisuga (Stiles 1982, Tamm et al. 1989, Scott 1994, Russell 1996). This group includes species that display similar " $\mathrm{U}$ " or " $\mathrm{J}$ " shaped dives, which vary mainly in height, angle, and diameter (Stiles 1983, Tamm et 
al. 1989). In Calothorax lucifer and Selasphorus scintilla, dive displays end with a zig-zag motion (Stiles 1983, Scott 1994). Other species are known to have aerial displays (e.g. Atthis heloisa, Ocreatus underwoodii, and Philodice bryantae; Feinsinger 1977, Schuchmann 1987, F. G. Stiles pers. comm.), however, to our knowledge, aerial displays accompanied by a song have been observed only in the Costa's Hummingbird (Calypte costae; Wells et al. 1978), Anna's Hummingbird (Calypte anna; Baptista and Matsui 1979), Royal Sunangel (Heliangelus regalis; Fitzpatrick et al. 1979), and the Sparkling Violet-ear (Colibri coruscans; Gaunt et al. 1994). Our observations of horizontal aerial displays accompanied by song are first recorded for Amethyst-throated Hummingbirds. Male dives have been interpreted as part of the courtship display of some hummingbird species (e.g. Tamm et al. 1989). However, that interpretation has been questioned given that aerial displays are also performed during male-male aggressive interactions (e.g. Stiles 1982).

Hummingbird vocalizations have been portrayed as mere "squeaks" of a twittering high-pitched nature (Johnsgard 1997). That assessment likely resulted from the pioneering studies of Ridgway (1892) and Skutch (1973) and probably contributed to the apparent lack of interest in conducting detailed studies of hummingbird sounds. Some hummingbird species sing simple one- or two-syllable songs (Amazilia candida, A. amabilis; Atwood et al. 1991, Kroodsma et al. 1996). Other species are intermediate in complexity (C. anna, C. coruscans, Colibri thalassinus, Amazilia decora, E. fulgens; Baptista and Schuchmann 1990, Gaunt et al. 1994, Kroodsma et al. 1996; Table 2). Song use in Lampornis seems intricate and extraordinarily complex (Table 2, Fig. 2), however, several species of Campylopterus stand out as versatile singers (i.e. number of syllable types and transitions from one syllable type to another) with long, elaborate and loud songs (Kroodsma et al. 1996; Table 2). Furthermore, song complexity is not restricted to trochiline hummingbirds. The song of the Rufous-breasted Hermit (Glaucis hirsuta) is a whistle-like song consisting of several introductory notes followed by notes of ascending and descending frequencies produced in different order (Jarvis et al. 2000). Irwin (1988) hypothesized that song complexity has been reduced during the course of evolution in some groups of birds. In hummingbirds, that complexity seems to have evolved independently and repeatedly during the course of hummingbird evolution. Despite that, the possible functions of this structured complexity are not known. We propose that this structured complexity may represent a lowcost strategy to communicate territory ownership, and therefore is more likely to evolve among large territorial hummingbirds that interact daily with several hummingbird species but do not engage in aggressive interactions.
Further species comparisons are limited because there is a lack of knowledge of hummingbird vocalizations. Most species studied to date congregate in leks and have simple songs (Atwood et al. 1991, Gaunt et al. 1994). However, none of the species for which a detailed sonographic analysis has been performed have songs approaching the acoustic and organizational complexity of Lampornis hummingbirds (Wagner 1954, Ficken et al. 2000, this study). These hummingbirds sing solitarily and they often inhabit dense vegetation. That ecological setting may explain in part the complexity of Lampornis male song (Ficken et al. 2000). However, song complexity, measured as number of syllable types and transitions from one syllable type to another (Table 2) was independent of whether hummingbird species inhabit dense vegetation $\left(\chi^{2}=4.45, \mathrm{df}=4, P>0.05, n=17\right)$ and whether sexes are plumage dimorphic $\left(\chi^{2}=\right.$ $5.09, \mathrm{df}=2, P>0.05, n=17)$. Interestingly, we have found a significant positive correlation between song complexity and body mass (grams; Spearman rank correlation, $r^{2}=0.69, P=0.005, n=17$; Table 2). These results support the hypothesis that song complexity is more likely to evolve among large, territorial hummingbirds. This correlation may explain the presence of female song in L. clemenciae (Ficken et al. 2000) and the use of agonistic aerial displays, as opposed to vocalizations, among the territorial, small-bodied "flame-throated" hummingbirds. Our results must be interpreted with caution because the number of syllables, syllable structure, and frequency levels of hummingbirds song may be strongly influenced by environmental and phylogenetic effects (see also McCracken and Sheldon 1997).

The complex interspecific interactions that hummingbirds experience every day may favor the evolution of diverse communication signals because they need to establish intra- and interspecific relationships, independently of habitat characteristics. Because territorial hummingbirds spend energy and time chasing intruders out of their floral territories, it would be useful to have low-cost strategies as to reduce (1) the energy expenditure required to defend floral resources, (2) the risk of injury by intruders, (3) the number of potential intruders, (4) the risk of predation, and (5) to be able to establish long-term relationships based on a complex acoustic system (see also Gaunt et al. 1994). Goldberg and Ewald (1991) found that the playback of the complex song of Anna's Hummingbirds on established territories benefited owners by deterring potential intruders. Although it is widely accepted that bird song is a mechanism for territorial defense and mate attraction (Morton 1986), the influence of interspecific interactions on the independent evolution of complex vocal signals among hummingbirds remains to be rigorously tested as more knowledge on hummingbird song is accumulated. 
Acknowledgments.-Comments by D. Kroodsma, S. M. Russell, R. Keller, C. R. Chandler, F. G. Stiles, D. Leger, S. Sealy, K. G. Smith, and two anonymous reviewers greatly improved earlier versions of this paper. L. González-Guzmán provided field assistance. We also thank T. Webber from the Department of Natural Sciences of the Florida Museum of Natural History, A. L. Priori from the Macaulay Library of Natural Sounds of the Cornell Laboratory of Ornithology, and D. Regelski and S. L. L. Gaunt from the Borror Laboratory of Bioacoustics of the Ohio State University for the technical support to obtain additional recordings for this study. This work was supported by a doctoral scholarship to J.F.O. (no. 56254) from the Consejo Nacional de Ciencia y Tecnología (CONACyT), and the James R. Silliman Memorial Research Grant. A research grant (no. H028) to J.F.O. from the Comisión Nacional para el Conocimiento y Uso de la Biodiversidad (CONABIO) allowed us to conduct this analysis. This paper is dedicated to the memory of our friend Luis F. Baptista.

\section{Literature Cited}

Atwood, J. L., V. L. Fitz, And J. E. Bamesberger. 1991. Temporal patterns of singing activity at leks of the White-bellied Emerald. Wilson Bulletin 103:373-386.

BAPTISTA, L. F. 1996. Nature and its nurturing in avian vocal development. Pages 39-60 in Ecology and Evolution of Acoustic Communication in Birds (D. E. Kroodsma and E. H. Miller, Eds.). Cornell University Press, Ithaca, New York.

BAptista, L. F., AND M. MAtsui. 1979. The source of the dive-noise of the Anna's Hummingbird. Condor 81:87-89.

BAptistA, L. F., AND K.-L. SChUChMANN. 1990. Song learning in the Anna Hummingbird (Calypte anna). Ethology 84:15-26.

Catchpole, C. K., And P. J. B. Slater. 1995. Bird Song: Biological Themes and Variations. Cambridge University Press, Cambridge, United Kingdom.

Charif, R. A., S. Mitchell, And C. W. Clark. 1995. CANARY 1.2.1 User's Manual. Cornell Laboratory of Ornithology, Ithaca, New York.

FEINSINGER, P. 1977. Notes on the hummingbirds of Monteverde, Cordillera de Tilarán, Costa Rica. Wilson Bulletin 89:159-164.

FICKEN, M. S., K. M. RUSCH, S. J. TAYLOR, AND D. R. POWERS. 2000. Blue-throated Hummingbird song: A pinnacle of nonoscine vocalizations. Auk 117:120-128.

FitzPatrick, J. W., D. E. Willard, AND J. W. TeRBORGH. 1979. A new species of hummingbird from Peru. Wilson Bulletin 91:177-186.

GAunt, S. L. L., L. F. BAPTISTA, J. E. SÁNCHEZ, AND D. HERNÁNDEZ. 1994. Song learning as evidenced from song sharing in two hummingbird species (Colibri coruscans and C. thalassinus). Auk 111:87-103.

GoldBerG, T. L., AND P. W. EWALD. 1991. Territorial song in the Anna's Hummingbird, Calypte anna: Costs of attraction and benefits of deterrence. Animal Behaviour 42:221-226.

Howell, S. N. G., AND S. WebB. 1995. A Guide to the Birds of Mexico and Northern Central America. Oxford University Press, New York.

IRWIN, R. E. 1988. The evolutionary importance of behavioural development: The ontogeny and phylogeny of bird song. Animal Behaviour 36:814824.

JARVis, E. D., S. Ribeiro, M. L. DA Silva, D. VENTURA, J. Vielliard, AND C. V. MELlO. 2000. Behaviourally driven gene expression reveals song nuclei in hummingbird brain. Nature 406:628-632.

JOHNSGARD, P. A. 1997. The Hummingbirds of North America, 2nd ed. Smithsonian Institution Press, Washington, D.C.

Kroodsma, D. E., J. M. E. Vielliard, AND F. G. STILES. 1996. Study of bird sounds in the Neotropics: Urgency and opportunity. Pages 269281 in Ecology and Evolution of Acoustic Communication in Birds (D. E. Kroodsma and E. H. Miller, Eds.). Cornell University Press, Ithaca, New York.

LARA, C., AND J. F. ORNELAS. 2001. Preferential nectar robbing of flowers with long corollas: Experimental studies of two hummingbird species visiting three plant species. Oecologia 128:263-273.

MCCRACKEN, K. G., AND F. H. SHELDON. 1997. Avian vocalizations and phylogenetic signal. Proceedings of the National Academy of Sciences USA 94:3833-3836.

MORTON, E. S. 1986. Predictions from the ranging hypothesis for the evolution of long distance signals in birds. Behaviour 99:65-86.

RIDGWAY, R. 1892. The Hummingbirds. Smithsonian Institution, U. S. National Museum, Washington, D.C.

Russell, S. M. 1996. Anna's Hummingbird (Calypte anna). In The Birds of North America, no. 226 (A. Poole and F. Gill, Eds.). Academy of Natural Sciences, Philadelphia, and American Ornithologists' Union, Washington, D.C.

SCHUCHMANN, K.-L. 1987. The display of the Booted Racket-tailed Hummingbird Ocreatus underwoodii, with notes on the systematic position of the genus. Bulletin of the British Ornithologists' Club 107:20-22.

SCHUCHMANN, K.-L. 1999. Family Trochilidae (Hummingbirds). Pages 468-535 in Handbook of the Birds of the World, vol. 5, Barn-owls to Hummingbirds (J. del Hoyo, A. Elliott, and J. Sargotal, Eds.). Lynx Editions, Barcelona, Spain.

ScotT, P. E. 1994. Lucifer Hummingbird (Calothorax lucifer). In The Birds of North America, no. 134 (A. Poole and F. Gill, Eds.). Academy of Natural 
Sciences, Philadelphia, and American Ornithologists' Union, Washington, D.C.

SKuTCH, A. F. 1973. The Life of the Hummingbird. Crown Press, New York.

Stiles, F. G. 1982. Aggressive and courtship displays of the male Anna's Hummingbird. Condor 84: 208-225.

STILES, F. G. 1983. Systematics of the southern forms of Selasphorus (Trochilidae). Auk 100:311-325.

TAmM, S., D. P. ARMSTRONG, AND Z. J. TOOZE. 1989. Display behavior of male Calliope Hummingbirds during the breeding season. Condor 91: 272-279.
WAGNer, H. O. 1954. Versuche einer Analyse der Kolibribalz. Zeitschrift für Tierpsychologie 11:182212.

Wells, S., R. BRadley, AND L. F. BAptista. 1978. Hybridization in Calypte hummingbirds. Auk 95: 537-549.

WILEY, R. H. 1971. Song groups in a singing assembly of Little Hermits. Condor 73:28-35.

Received 28 June 2001, accepted 8 June 2002.

Associate Editor: S. G. Sealy

ApPENDIX. Sources and localities for recordings used in this studya.

\begin{tabular}{llllll}
\hline \hline \multicolumn{1}{c}{ Species } & \multicolumn{1}{c}{ Context } & \multicolumn{1}{c}{ Locality } & Date & Recorder & Catalogue no. \\
\hline L. viridipallens & Unknown & SA: El Salvador & Oct/1972 & W.A. Thurber & LNS \#06161 \\
L. clemenciae & Male perched & US: Arizona & Jun/1977 & H. Barker & LNS \#25122 \\
E. fulgens & Unknown & CR: Cerro de la Muerte & Jan/1987 & F.G. Stiles & FMNH \#1046B \\
\hline
\end{tabular}

${ }^{a} \mathrm{CR}=$ Costa Rica, US = United States of America, SA = El Salvador; LNS = Macaulay Library of Natural Sounds (Cornell Laboratory of Ornithology), FMNH = Sound Collection (Florida Museum of Natural History).

The Auk 119(4):1149-1154, 2002

\title{
Extreme Between-Year Variation in Productivity of a Bridled Titmouse (Baeolophus wollweberi) Population
}

\author{
BETH J. CHRISTMAN ${ }^{1}$ \\ Department of Ecology and Evolutionary Biology, Corson Hall, Cornell University, Ithaca, New York 14853, USA
}

\begin{abstract}
Environmental variability affects lifehistory decisions such as allocation of resources to reproduction. However, in the case of small passerine birds, pairs that acquire a territory do not usually skip a breeding season. This study presents breeding-success data from two contrasting years for a population of Bridled Titmice (Baeolophus wollweberi). During an El Niño year (1998), 20 pairs attempted to breed, and $85 \%$ were successful. Survival of juveniles from 10 banded broods through nutritional independence was $100 \%$, excluding one depredated nest. Breeding success was much lower in the following La Niña drought year. Fifty-seven pairs established territories in the study area. Twenty-seven never progressed to nest building. Thirteen pairs were successful; survival of young from banding to nutritional independence was $41.4 \%$. An average of 0.47 fledglings per breeding pair was produced in 1999, compared to 4.40 the previous
\end{abstract}

${ }^{1}$ Present Address: P.O. Box 1294, Truckee, California 96160, USA. E-mail: bjc14@cornell.edu
El Niño year. This study examines possible adaptive significance of forgoing breeding in a poor year.

RESUMEN.-La variabilidad ambiental afecta las decisiones de historia de vida, tales como la asignación de recursos a la reproducción. Sin embargo, parejas de pequeñas aves paserinas que adquieren un territorio, usualmente no dejan de reproducirse en una estación de cría. Aquí se presentan datos del éxito reproductivo de una población de Baeolophus wollweberi en dos años contrastantes. Durante un año El Niño (1998) veinte parejas intentaron reproducirse de las cuales un $85 \%$ tuvo éxito. La supervivencia hasta el periodo de independencia nutricional de juveniles pertenecientes a 10 nidadas marcadas fue de un $100 \%$ excluyendo un nido depredado. El éxito reproductivo fue mucho más bajo en el siguiente año de seca correspondiente a La Niña. Cincuenta y siete parejas establecieron territorios en el área de estudio. Veintisiete nunca llegaron a finalizar la construcción del nido. Trece parejas tuvieron éxito y la supervivencia de juveniles desde el marcaje a la indepen- 
dencia nutricional fue de un 41.4\%. En 1999 se produjeron en promedio 0.47 volantones por pareja reproductiva, en comparación a 4.40 volantones por pareja durante el año El Niño anterior. Se discute la posible importancia adaptativa de abandonar la cría durante un año pobre.

Between-year variability in environmental quality has been predicted to influence optimal allocation of resources to reproduction (Cohen 1966, Schaffer 1974). When environmental variability experienced by a population is random, selection should act to maximize individual fitness based on long-term probability of good versus bad years (Cohen 1967). However, if cues are available to individuals prior to onset of breeding, that indicate environmental quality affecting reproduction that year individuals are predicted to modify their reproductive effort accordingly dependent upon reliability of cues. In the case of completely reliable predictors, a strictly on-off response may be expected to evolve (Cohen 1967).

El Niño and La Niña conditions produce strong environmental variability (Taylor 1998) and have been demonstrated to have significant effects on natural populations (Grant et al. 1987, Li and Brown 1999, Sillett and Grant 2000). This study presents data from one El Niño and La Niña cycle and explores relative adaptive value of different individual behaviors within a population when breeding conditions are poor. Specifically, are there sets of conditions under which a passerine bird could yield higher lifetime fitness by skipping a breeding season, or is such a response likely to be simply a reflection of a constraint? Here data are presented on breeding success in a Bridled Titmouse (Baeolophus wollweberi) population from two years of contrasting conditions, and the relative adaptive value of forgoing breeding in a bad year is discussed.

Methods.-Bridled Titmice are small ( $\sim 10 \mathrm{~g})$, cavity nesting, arthropod generalists, in the family Paridae (chickadees, titmice, and tits). They are resident throughout their range-mountainous regions of Mexico, southeastern Arizona, and southwestern New Mexico (Nocedal and Ficken 1998). Bridled Titmice are fairly abundant in oak woodlands and along narrow riparian corridors in those mountains, forming flocks during winter. Although little research has been done on this species (Nocedal and Ficken 1998), numerous investigations pertaining to optimal clutch size, cost of reproduction, and population dynamics have been undertaken with other parid species (e.g. Perrins 1965, Orell and Ojanen 1983, Loery and Nichols 1985, Ekman and Askenmo 1986, Boyce and Perrins 1987, Nur 1988).

This study was conducted in the Chiricahua mountains, Cochise County, Arizona $\left(32^{\circ} \mathrm{N}, 109^{\circ} \mathrm{W}\right)$ between 1,600 and $1,700 \mathrm{~m}$ in elevation. Breeding territories of Bridled Titmice were monitered along the main and north forks of Cave Creek. Riparian zones

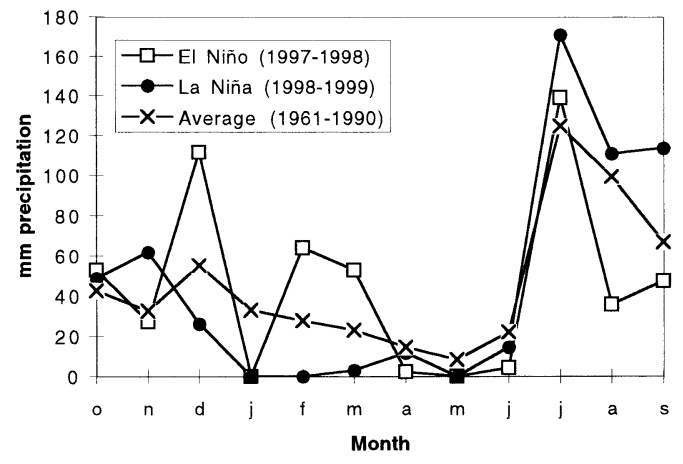

FIG. 1. Rainfall data (monthly totals) for 1998, 1999, and the average for the period 1961-1990. Open boxes represent data from 1997-1998 (El Niño), closed circles represent data from 1998-1999 (La Niña), $\times$ represents average rainfall data from 1961-1990. Data were collected at the Southwestern Research Station in Portal, Arizona, and reported by the National Oceanic and Atmospheric Administration.

composed of Arizona sycamore (Platanus wrightii), Fremont cottonwood (Populus fremontii), Arizona white oak (Quercus arizonica), and alligator juniper (Juniperus deppeana) appear to be favored breeding habitat of titmice. Oak-juniper woodlands primarily composed of Arizona white oak, Emory oak (Q. emorii), and alligator juniper were also used as foraging areas and breeding habitat in some years by Bridled Titmice. Oaks were most frequently used foraging substrate during most of the year (Nocedal and Ficken 1998, Christman 2001a, B. J. Christman unpubl. data). Arizona white oak and Emory oak were the most abundant oak species present in the study area, characteristically retaining their leaves throughout winter and dropping them in spring. In a typical year, new leaves grow immediately. Caterpillars found on oak leaves are a common prey item of Bridled Titmice during both nestling and fledgling stages (B. J. Christman unpubl. data).

Southeastern Arizona is strongly affected by summer monsoons, with almost half the yearly precipitation occurring in July and August. Winter rain and snow (December through February) account for the other half. The two years of this study (1998 and 1999) varied strongly in winter and spring precipitation, with El Niño winter and spring (1997-1998) much wetter than the following La Niña year (Fig. 1).

The Bridled Titmouse population was studied year round from December 1997 to October 1999. Each spring territorial pairs' nests were located within a bounded region in Cave Creek Canyon of $\sim 4 \mathrm{~km}^{2}$ (determined from maps), and their progress was monitored through the onset of breeding with daily trips to the field during the 1998 and 1999 breeding season (March through July). The study area consisted of seven subareas. Each subarea was visited at 
TABLE 1. Comparison of Bridled Titmouse breeding success between an El Niño (1998) and a La Niña year (1999).

\begin{tabular}{cccccccc}
\hline \hline Year & $\begin{array}{c}\text { Number of } \\
\text { pairs }\end{array}$ & $\begin{array}{c}\text { Number } \\
\text { attempting } \\
\text { to breed }\end{array}$ & Failed & Fledged $^{\mathrm{a}}$ & $\begin{array}{c}\text { Fledglings/ Fledglings/ Fledglings/ } \\
\text { pair in } \\
\text { population }\end{array}$ & $\begin{array}{c}\text { breeding } \\
\text { pair }\end{array}$ & $\begin{array}{c}\text { successful } \\
\text { pair }\end{array}$ \\
\hline 1998 & 20 & $20(100 \%)$ & $3(15 \%)^{\mathrm{b}}$ & $17(85 \%)$ & 4.40 & 4.40 & 5.18 \\
1999 & 57 & $30(53 \%)$ & $17(30 \%)^{\mathrm{c}}$ & $13(23 \%)$ & 0.21 & 0.40 & 0.92
\end{tabular}

a Number of nests that fledged young surviving to nutritional independence.

${ }^{\mathrm{b}}$ Failed during nesting.

c Eight failed before the onset of incubation, nine failed during nesting.

least once every third day during 1998 (often more frequently), and at least every other day in 1999. Territories were identified by recording possessive behavior (vocalizations, chases, and fights). During the early part of the breeding season, Bridled Titmice frequently engage in territorial behavior, which facilitated determining territory boundaries. All observed behaviors throughout the early breeding season were used to determine territory boundaries. Because adult titmice were banded on the nest, a large portion of the population was unbanded during territory establishment. Numbers of banded birds were sufficient for determining total number of territorial pairs in the study area $(30 \%$ banded before nesting in 1998 and 35\% banded before nesting in 1999). However, after previously unbanded birds were banded during nesting, the understanding of territory boundaries and number of territories never changed.

It was possible to accurately assess the breeding cycle phase due to behavior exhibited by the titmice. Bridled Titmouse females switch to a distinctive vocalization as soon as they begin to place nesting material in a cavity (B. J. Christman pers. obs.), akin to the "broken dee" call of Black-capped Chickadees (Poecile atricapillus; Ficken et al. 1978). This behavior indicated when nest building had begun even if the nest had not yet been located.

Chicks within reasonably accessible nests were banded, and all nests were observed to obtain success data including number of fledglings that survived for three weeks after fledging. Nests ranged in height from 1 to over $12 \mathrm{~m}$. Many cavities were located in limbs that were inaccessible, so it was not possible to band all chicks in the population. Mayfield estimates (a method that corrects for the amount of time a nest is under observation; Mayfield 1975) of nesting success were not made because all territorial pairs in the study area were under observation for the entire breeding season. Banded broods were followed for a minimum of two months after fledging as part of a study on juvenile dispersal (Christman 2001b).

Males may hold their territories for life, although females were observed to change territories in the event of divorce or death of their mate (B. J. Christ- man pers. obs.). Because of that apparent strong site fidelity of males and due to daily observation, detectability for males may have been quite high. Four females were found that divorced and changed territories (up to $2 \mathrm{~km}$ from their previous breeding sites), indicating that detectability may have been high for females as well, although resighting rates are likely to be lower than for males.

Results.-Twenty pairs established territories in the study area in 1998 (El Niño year). All pairs attempted to breed; three failed completely during the nesting attempt and one nest was partially depredated during the nestling period. One of the three failed nests was depredated, but the cause of failure for the other two was unknown because the nests were in inaccessible trees. One pair successfully raised two broods. Ten of the nests in the study area for banding were accessed, nine of which fledged young. Nestlings in two other nests that were of fledging age were counted. Average number of nestlings present in those 12 nests at banding or inspection was $4.5(\mathrm{SD}=0.80)$. One nest contained five chicks and two eggs, indicating maximum clutch size was at least seven in that population.

Survival of juveniles from banding to three weeks postfledging (when fledglings are capable of independent foraging) was $100 \%$, excluding one case of nest predation on a banded brood.

Fifty-seven pairs established territories in the study area in 1999 (La Niña year). Twenty-seven $(47.4 \%)$ never progressed to nest building. Those twosomes appeared to be pairs-all were observed inspecting cavities together, and courtship feeding was observed. Thirteen pairs (22.8\%) fledged young that survived for at least three weeks. Of the other 17 pairs, eight built nests but never began incubating, seven failed after eggs hatched, and two lost their fledglings. Starvation was the apparent cause of nestling death in the nests for which a cause could be determined.

Nestlings in 11 nests were banded. Average number of nestlings per nest at banding was 2.5 (SD = 0.93). Survival from banding until three weeks of age was $41.4 \%$ (12 of 29 fledglings banded). Four clutches of eggs that were counted had five $(n=3)$ or six $(n$ $=1$ ) eggs (see Table 1 ). 
The most visually striking result of La Niña drought conditions during the 1999 breeding season was the response of oak trees. In 1999, oaks dropped their leaves in the spring as is typical. However, the majority of trees remained leafless until mid-July. All existing breeding territories in 1999 were along creek drainages where sycamores and cottonwoods were present. Those deciduous trees did leaf-out in the spring.

Fifty-seven percent of males present in the population in 1998 were present in 1999, and 64\% of females present in the population in 1998 were present in 1999. These estimates are from a small number of total individuals-14 males and 14 females.

Discussion.-In an extremely dry year, nearly half of territorial pairs in a population of presumably short-lived passerines made no attempt to breed. Bridled Titmice behavior during the 1999 breeding season raises the question, Could not breeding have been an adaptive "choice" made by nonbreeders, or did birds not breed because they faced a constraint? Parids are typically considered to have life-history traits of large clutches and low survivorship of both adults and juveniles (Perrins 1979, Smith 1991), with lifetime reproductive success strongly influenced by number of breeding attempts. The possibility that skipping a breeding season could be adaptive initially appears counter intuitive. However, there are reasons to believe that in the case reported here, not breeding may have been an adaptive choice.

An apparently reliable cue was available to Bridled Titmice indicating how poor conditions would be for raising young in 1999, that is, the lack of oak leaves. Although this species is an arthropod generalist, oak leaves are an important foraging substrate for Bridled Titmice during summer (Nocedal and Ficken 1998; B. J. Christman pers. obs.). Such good indicators of upcoming breeding season quality may not often be available to natural populations of animals. Temporal variation on the scale of La Niña events may be a difficult challenge for adaptation in natural populations. In the period between 1950 and 1999, 12 years could be classified as La Niña years, with only 3 of those (including 1999) being considered exhibiting strong La Niña conditions (See Acknowledgments). Droughts certainly occur for other reasons as well, however severe ones such as that of 1999 may be uncommon. Bridled Titmice are not the only passerines in the Chiricahua Mountains that are affected by El Niño Southern Oscillation cycles (Li and Brown 1999).

The decision of whether or not to breed in a poor year should be based on whether the benefit of breeding is greater than the cost of breeding in that year. If the cost is associated with breeding for adults (such as decreased future fecundity or decreased survival) and likelihood of surviving to the next breeding event is high, then forgoing breeding under poor conditions would be an adaptive response. Em- pirical support for a cost of reproduction in tits is mixed. Clutch-size manipulation experiments show either a slight effect or no effect of increased brood size on adult survival (Boyce and Perrins 1987, Orell and Koivula 1988, Nur 1988, Pettifor 1993). On the other hand, Ekman and Askenmo (1986) found a difference in survival between nonbreeding and breeding male Willow Tits (Parus montanus) of $\sim 20 \%$. Great Tit (Parus major) females that had their second brood removed displayed a $20 \%$ increase in survival compared to those that did not, although only in low-quality habitat in poor years (Verhulst 1998).

If survival through the nonbreeding season is unlikely, organisms should breed regardless of the cost. Whereas over-winter survival can be low for other parids, survival could be higher for Bridled Titmice. Resighting rates reported here are not much greater than survival rates reported for other species of tits, but resighting rates are an absolute minimum survival rate. Winter environmental conditions experienced by Bridled Titmice are much milder than those experienced by other well-studied parid species. Many of the same winter rank-related costs suffered by subordinate tits were not found in this population (Christman 2001a), which may enhance over-winter survival of subordinates.

It is also possible that the response of birds in that population in 1999 reflected a constraint on breeding ability. Two potential constraints that the birds could have faced are density dependence and differences in individual quality.

The number of pairs present in the same geographic area was almost $3 \times$ greater in 1999 than in 1998. Breeding density may have been low in 1998 because monsoon rains were late and not heavy in 1997 and breeding success appeared low (B. J. Christman pers. obs., S. Gaulin pers. comm.). Regardless, density was high in 1999. The influx of birds into the study area was likely a combination of extremely high breeding success in 1998 and that titmice were more concentrated along stream courses compared to the wetter year because those areas contained the only trees in the study that had leaves (providing a foraging substrate). Population density has been shown to have a negative effect on reproduction in many studies of tits (Perrins 1965, Dhondt 1977, O'Connor 1980, Ekman 1984, Dhondt et al. 1992). Effects of high population density observed in those studies included, decreases in clutch size, or juvenile survivorship, and do not include adults forgoing breeding.

Different classes of individuals react differently to environmental stress (Dhondt et al. 1990). It is possible that birds that did not attempt to breed were qualitatively different than those that did, either that "better" birds were able to breed or that better birds responded to environmental cues and did not breed. For this study, it was only possible to make limited comparisons between first-year breeders and more 
TABLE 2. Comparisons of breeding success for different age classes of individuals.

\begin{tabular}{lcccc}
\hline \hline $\begin{array}{c}\text { Age classes } \\
\text { of pair members }^{\text {a }}\end{array}$ & $n$ & $\begin{array}{c}\text { Never } \\
\text { start }\end{array}$ & Fail & Succeed \\
\hline AM + AF & 7 & 2 & 3 & 2 \\
AM + UF & 3 & 1 & 1 & 1 \\
JM + AF & 1 & 0 & 0 & 1 \\
JM + UF & 9 & 3 & 5 & 1 \\
TOTAL & 20 & 6 & 9 & 5 \\
\hline
\end{tabular}

a $\mathrm{AM}=$ adult male, $\mathrm{AF}=$ adult female, $\mathrm{JM}=$ juvenile male, $\mathrm{UF}=$ unknown aged female.

experienced breeders due to the number of unbanded birds in the population. There were 20 pairs in which one or both of the members were of known age in 1999 (out of 57 pairs). No strong trend appeared from comparisons between different age classes of individuals (Table 2), however sample sizes were too small to draw any conclusions.

Environmental variability that affects production of offspring, but not survival rate of adults, is expected to result in reduced reproductive effort. Conversely, environmental variability that affects only adult survival is predicted to lead to an increase in reproductive output (Schaffer 1974). The assumption that drought conditions of 1999 had a much greater effect on offspring production than adult survival appears valid. Adult survival was high throughout the 1999 breeding season. As mentioned above, the extent to which an expected decrease in offspring production can be predicted before reproduction begins also serves to decrease reproductive output (Cohen 1967). The idea that increasing present reproductive effort only when future reproduction is not disproportionately sacrificed is central to understanding the evolution of life histories (Williams 1966, Goodman 1974, Stearns 1992). If survival and reproduction do tradeoff for Bridled Titmice to a significant degree, then skipping reproduction in an extremely bad year like 1999 is a response consistent with theoretical predictions.

Acknowledgments. - C. Ray provided invaluable assistance chasing titmice during the spring of 1999, as well as excellent moral support in the spring of 1998. T. Malone also provided field help during a pinch as well as other various types of help throughout the course of this study. Many great discussions were had throughout the course of this work with S. Gaulin. I would like to thank the Southwestern Research Station for use of facilities and the Coronado National Forest allowing me to work on the study area. I am grateful to the Gehlbachs for use of their ladder and ladder crew. I was supported by a National Science Foundation Graduate Fellowship and a Treman Fellowship for Ornithology during this research. Additional sources of financial aid were Benning Grant from Eaton Birding Club, Cornell Graduate School, Cornell Chapter of Sigma Xi, and a Frank M. Chap- man Award from the American Museum of Natural History. A. Dhondt encouraged me to write up these results and provided helpful comments on the manuscript. For more information on El Niño and La Niña during 1950-1999, see www.nws.noaa.gov. Helpful comments were provided by F. Thompson, N. Nur, and an anonymous reviewer.

\section{Literature Cited}

Boyce, M. S., ANd C. M. Perrins. 1987. Optimizing Great Tit clutch size in a fluctuating environment. Ecology 68:142-153.

Christman, B. J. 2001a. Low flock coherence in mild winters leads to a lack of subordination costs in Bridled Titmouse foraging groups. Ibis 143:617626.

CHRIstman, B. 2001b. Influences on the social organization of two southwestern titmice. Ph.D. dissertation, Cornell University, Ithaca, New York.

COHEN, D. 1966. Optimizing reproduction in a randomly varying environment. Journal of Theoretical Biology 12:119-120.

COHEN, D. 1967. Optimizing reproduction in a randomly varying environment when a correlation may exist between the conditions at the time a choice has to be made and the subsequent outcome. Journal of Theoretical Biology 16:1-14.

DHONDT, A. A. 1977. Interspecific competition between Great and Blue tit. Nature 268:521-523.

DhOndT, A. A., B. KempenaERs, AND F. AdRIAENSEN. 1992. Density dependent clutch size caused by habitat heterogeneity. Journal of Animal Ecology 61:643-648.

Dhondt, A. A., E. Matthysen, F. Adriaensen, And M. M. LAMBRECHTS. 1990. Population dynamics and regulation of a high density Blue Tit population. Pages 39-53 in Population Biology of Passerine Birds, NATO ASI Series vol. G 24 (J. Blondel, A. Gosler, J.-D. Lebreton, and R. McCleery, Eds.). Springer-Verlag, Berlin.

EKMAN, J. 1984. Density-dependent seasonal mortality and population fluctuations of the temperatezone Willow Tit (Parus montanus). Journal of Animal Ecology 53:119-134.

EKMAN, J., AND C. Askenmo. 1986. Reproductive cost, age-specific survival and a comparison of the reproductive strategy in two European tits (genus Parus). Evolution 40:159-168.

FiCKEN, M. S., R. W. FICKEN, AND S. R. WitKIN. 1978. Vocal repertoire of the Black-capped Chickadee. Auk 95:34-48.

Goodman, D. 1974. Natural selection and a cost ceiling on reproductive effort. American Naturalist 108:247-268.

GRANT, P. B., AND B. R. GRANT. 1987. The extraordinary El Niño event of 1982-83: Effects on Darwin's finches on Isla Genovesa, Galápagos. Oikos 49:55-66. 
LI, S. H., AND J. L. BROWN. 1999. Influence of climate on reproductive success in Mexican Jays. Auk 116:924-936.

Loery, G., AND J. D. Nichols. 1985. Dynamics of a Black-capped Chickadee population, 1958-1983. Ecology 66:1195-1203.

MAYFIELD, H. F. 1975. Suggestions for calculating nest success. Wilson Bulletin 87:456-466.

Nocedal, J., AND M. S. FicKen. 1998. Bridled Titmouse (Baeolophus wollweberi). In Birds of North America, no. 375 (A. Poole and F. Gill, Eds.). Academy of Natural Sciences, Philadelphia, and American Ornithologists' Union, Washington, D.C.

NuR, N. 1988. The consequences of brood size for breeding Blue Tits. III. Measuring the cost of reproduction: Survival, future fecundity, and differential dispersal. Evolution 42:351-362.

O'Connor, R. J. 1980. Pattern and process in Great Tit (Parus major) populations in Britain. Ardea 68:165-183.

Orell, M., AND K. Koivula. 1988. Cost of reproduction: Parental survival and production of recruits in the Willow Tit Parus montanus. Oecologia 77:423-432.

Orell, M., AND M. OJAnen. 1983. Breeding biology and population dynamics of the Willow Tit Parus montanus. Annales Zoologici Fennici 20:99-114.

Perrins, C. M. 1965. Population fluctuations and clutch size in the Great Tit, Parus major. Journal of Animal Ecology 34:601-647.
Perrins, C. M. 1979. British Tits. William Collins and Co., Glasgow Scotland.

Pettifor, R. A. 1993. Brood-manipulation experiments: II. A cost of reproduction in Blue Tits $(\mathrm{Pa}-$ rus caeruleus)? Journal of Animal Ecology 62: 145-159.

SCHAFFER, W. J. 1974. Optimal reproductive effort in fluctuating environments. American Naturalist 108:783-790.

Sillett, T. S., R. T. Holmes, AND T. W. SHERry. 2000. Impacts of a global climate cycle on population dynamics of a migratory songbird. Science 288 : 2040-2042.

SMith, S. M. 1991. The Black-capped Chickadee: Behavioral Ecology and Natural History. Cornell University Press, Ithaca, New York.

Stearns, S. C. 1992. The Evolution of Life Histories. Oxford University Press, Oxford.

Taylor, A. H., M. B. Jordan, and J. A. Stephens. 1998. Gulf Stream shifts following ENSO events. Nature 393:638.

VERHULST, S. 1998. Multiple breeding in the Great Tit, II. The costs of rearing a second clutch. Functional Ecology 12:132-140.

Williams, G. C. 1966. Adaptation and Natural Selection. Princeton University Press, Princeton, New Jersey.

Received 29 January 2001, accepted 17 July 2002.

Associate Editor: F. Thompson III

The Auk 119(4):1154-1161, 2002

\title{
Annual Migration Density and Stopover Patterns of Northern Saw-whet Owls (Aegolius acadicus)
}

\author{
David M. Whalen, ${ }^{1,3}$ AND Bryan D. WATtS ${ }^{2}$ \\ ${ }^{1}$ Department of Biology, University of New Mexico, Albuquerque, New Mexico 87131, USA; and \\ ${ }^{2}$ Center for Conservation Biology, College of William and Mary, Williamsburg, Virginia 23187, USA
}

\begin{abstract}
Northern Saw-whet Owls (Aegolius acadicus) exhibit large fluctuations in annual number of individuals migrating in eastern United States. Underlying large differences in the magnitude of the migration may be important density-dependent effects on body condition and stopover patterns. We investigated such effects using data from saw-whet owls that were trapped and banded during autumn migration at the southern tip of the Delmarva Peninsula (near Cape Charles, Virginia) from 1994 to 2000. Irruptive migration events occurred in 1995
\end{abstract}

\footnotetext{
${ }^{3}$ E-mail: dwhalen@sevilleta.unm.edu
}

and 1999 when 1,002 and 700 owls were captured, respectively. Capture totals ranged from 22 to 105 owls during five nonirruptive years. Irruptive migration years were dominated by immature owls ( $82 \%$ of captures) and were characterized by low recapture rates $(13 \%)$ and shorter minimum stopover lengths (median $=5$ nights) for all owls. Body masses and body-condition index scores were significantly lower for both immature and adult age classes during years when owl density was very high. During such years, a smaller percentage of owls elected to stopover and, among those that did, individuals in good condition departed sooner than individuals 
in poor condition. Conversely, during nonirruptive years, adults constituted $67 \%$ of captures, recapture rates were nearly $3 \times$ higher $(35 \%)$, and stopover lengths were twice as long (median $=10$ nights). Recapture rates were significantly higher for adults (43\%) than for immature owls (23\%) and initial body condition of adults was positively correlated with their length of stopover. During light migration years, conditions may be conducive for extended residency, particularly for adult owls in good condition. Our results suggest that density-dependence is an important mechanism driving migration and stopover patterns of saw-whet owls.

RESUMEN.-Aegolius acadicus presenta grandes fluctuaciones en el número anual de individuos que migran en el este de Estados Unidos. Subyacentes a las grandes diferencias en la magnitud de la migración pueden estar los importantes efectos de la denso-dependencia sobre la condición corporal y los patrones de paradas durante la migración. Investigamos estos efectos usando datos de captura y marcaje de Aegolius acadicus durante la migración de otoño desde 1994 al 2000, en la punta sur de la Península de Delmarva (cerca de Cape Charles, Virginia). Los eventos de migración masiva ocurrieron en 1995 y 1999 cuando se capturaron 1,002 y 700 búhos, respectivamente. Los totales de captura variaron entre 22 a 105 búhos durante los cinco años no masivos. Los años de migración masiva fueron dominados por búhos inmaduros ( $82 \%$ de las capturas) y se caracterizaron por bajas tasas de recaptura $(13 \%)$ y por tiempos mínimos de parada más cortos (mediana $=$ 5 noches) para todos los búhos. El peso corporal y el índice de condición corporal para las clases de edad inmadura y adulta fueron significativamente más bajos durante los años en que la densidad de búhos fue muy alta. Durante aquellos años, un menor porcentaje de búhos hizo escalas durante la migración, y entre aquéllos que pararon, los individuos en mejor condición partieron antes que los individuos en condición más pobre. Por el contrario, durante los años no masivos, los adultos constituyeron un $67 \%$ de las capturas, las tasas de recaptura fueron casi 3 veces superiores (35\%), y el tiempo de la parada fue dos veces más largo (mediana $=10$ noches). Las tasas de recaptura fueron significativamente más altas para los adultos (43\%) que para los búhos inmaduros (23\%) y la condición corporal inicial de los adultos se correlacionó positivamente con el tiempo de parada. Durante los años de migración menos masiva, las condiciones locales pueden favorecer la extensión de la residencia, particularmente para los búhos adultos en buena condición. Nuestros resultados sugieren que la denso-dependencia es un mecanismo importante que influencia los patrones de migración y paradas de los búhos.

Seasonal availability of resources has long been considered the primary cause of bird migration
(Lack 1954, 1968; Gauthreaux 1982). Each year, billions of birds withdraw from high latitudes to avoid severe food shortages and maximize their probability of survival during the nonbreeding season. However, migratory movements are very energetically demanding (Blem 1980). As a result, most migrating birds stop periodically to replenish energy reserves and therefore resource availability continues to play an important role during migration (Hutto 1985, Martin and Karr 1986).

In addition to seasonal declines in absolute levels of food resources, resource availability may be affected by consumer density through competition. Indeed, leading models of bird migration have incorporated population density and competition as important factors that drive migratory movements (Cohen 1967, Fretwell 1972). Empirical evidence also suggests that competition plays an important role during migration (Rappole and Warner 1976, Moore and Yong 1991). Although numerous studies have shown that energetic condition (i.e. fat stores or sizeadjusted body mass) is an important factor influencing stopover decisions (e.g. Moore and Kerlinger 1987, Dunn et al. 1988, Morris et al. 1996), the influence of migrant density on body condition and stopover patterns has been scarcely studied.

One of the most common nonpasserine bird species banded during autumn migration in the eastern United States is the Northern Saw-whet Owl (Aegolius acadicus; Brinker et al. 1997). Recent banding studies, employing electronic audiolures that broadcast a continuous saw-whet owl call to attract migrating owls, have demonstrated that the species is an irruptive migrant in the region (Brinker et al. 1997, Whalen et al. 1997). Despite fairly consistent trapping efforts, there has been huge variation in the annual number of owls captured on the Atlantic coast during recent years. Irruptive migration events occurred in 1995 and 1999 as capture rates were several times higher than in any other year. Relatively high passive (without the use of an audiolure) capture rates of owls at Cape May, New Jersey, during 1980 and 1981 (Duffy and Kerlinger 1992) and at songbird banding stations in the eastern United States during 1965 (Davis 1966) suggest that those years also constituted major migration events.

Compared to most raptorial birds, saw-whet owls are a very small-bodied species (60-120 g) with high mass-specific metabolic costs (Nagy 1987). In addition, as a nocturnal species, saw-whet owls fly using powered flapping flight (Cannings 1993), an energetically expensive mode of locomotion (Hedenstrom 1993). Presumably to fuel such high rates of energy expenditure, owls continue to forage during migration (Russell et al. 1991, Whalen et al. 2000).

The aim of this study was to investigate body condition and stopover patterns of migrating saw-whet owls in relation to the irruptive nature of their migration. We examined effects of annual owl density 


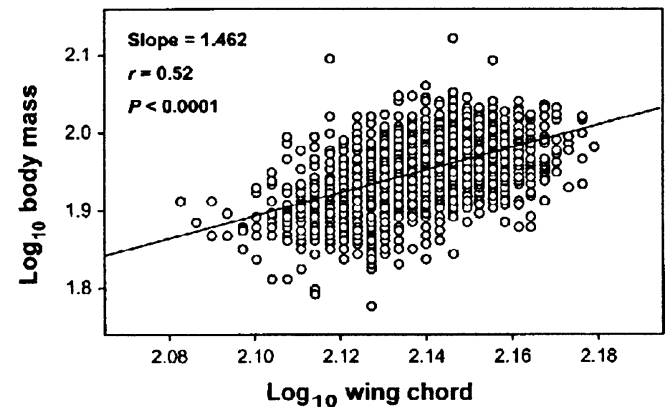

FIG. 1. Log-log plot of body mass versus wing chord for all saw-whet owls captured $(n=2,048)$. The slope of this relationship was used as the scaling exponent in the body-condition index mass/wing chord $^{1.462}$. This technique eliminates residual correlation between body condition scores and wing chord.

on body condition, probability of extended stopover, and length of stopover. By controlling for annual owl density, we also addressed more direct relationships between body condition and stopover patterns. Finally, because experience is likely to influence competitive abilities and stopover decisions of migrating birds (Woodrey 2000), we studied age-specific effects.

Methods.-Migrating saw-whet owls were trapped and banded on the Eastern Shore of Virginia each autumn from late October to mid-December, 19942000. To enhance both capture and recapture rates, owls were trapped at three separate wooded sites located within a $10 \mathrm{~km}^{2}$ area at the southern tip of the Delmarva Peninsula. The three sites were located on the Eastern Shore of Virginia National Wildlife Refuge, Gatr Tract Wildlife Management Area, and Kiptopeke State Park. Birds arriving in that area during autumn migration are faced with a barrier of $\sim 30 \mathrm{~km}$ of open water in the form of the Chesapeake Bay.
Most individuals trapped on the Delmarva Peninsula are believed to come from breeding populations in Canada and the northeastern United States (Brinker et al. 1997).

Each of the three trapping sites in our study consisted of a continuous line of mist-nets $72 \mathrm{~m}$ long and $2 \mathrm{~m}$ tall. An electronic audiolure, consisting of a cassette tape player, amplifier, loudspeaker, and 12 volt marine battery, was situated at the center of each net lane to attract migrating owls. A continuous-loop broadcast of a saw-whet owl "advertising call" (Cannings 1993) was played at an estimated sound output of $100 \mathrm{db}$ at $2 \mathrm{~m}$.

Mist-netting was initiated at dusk and continued until dawn each night. Owls were not trapped on nights with significant precipitation or strong winds. Captured owls were banded with federal aluminum leg bands. Wings were inspected for evidence of molt to determine age (Evans and Rosenfield 1987). Because immature (hatching-year, hereafter HY) sawwhet owls retain all juvenal flight feathers during their first year (Cannings 1993), birds were classified as immature if all primary and secondary remiges and coverts appeared uniform in color. Because adult (after-hatching-year, hereafter AHY) saw-whet owls undergo a definitive prebasic molt in which the remigial molt is incomplete in summer (Cannings 1993), owls were classified as adults if primary and secondary remiges were not uniform in color, indicating the presence of more than one generation of feathers. Unflattened wing-chord measurements were recorded to the nearest millimeter and body mass was recorded to the nearest gram using a Pesola spring scale or a digital scale.

A conventional body condition index of mass/ wing chord was not used because mass and wing chord do not scale linearly. As a result, body condition scores based on such an index would be correlated with wing chord $(r=0.18, t=8.05, P<$ $0.0001, n=2,048)$. Hence, size biases could confound

TABLE 1. Annual number of saw-whet owl captures, distribution by age class, and number of recaptures on the Lower Delmarva Peninsula near Cape Charles, Virginia. HY (hatching-year) indicates immature owls. AHY (after-hatching-year) indicates adult owls.

\begin{tabular}{lcccccr}
\hline \hline Year & $\begin{array}{c}\text { Owl } \\
\text { captures }\end{array}$ & $\begin{array}{c}\text { HY } \\
\text { captures }^{\mathrm{a}}\end{array}$ & $\begin{array}{c}\text { AHY } \\
\text { captures }^{\mathrm{a}}\end{array}$ & $\begin{array}{c}\text { Owl } \\
\text { recaptures }^{\mathrm{b}}\end{array}$ & $\begin{array}{c}\text { HY } \\
\text { recaptures }^{\mathrm{b}}\end{array}$ & $\begin{array}{c}\text { AHY } \\
\text { recaptures }^{\mathrm{b}}\end{array}$ \\
\hline 1994 & 52 & 21 & 31 & $21(40.4)$ & $4(19.0)$ & $17(54.8)$ \\
$1995^{\mathrm{c}}$ & 1,002 & 825 & 162 & $130(12.9)$ & $109(13.2)$ & $19(11.7)$ \\
1996 & 105 & 15 & 90 & $33(31.4)$ & $1(6.7)$ & $32(35.6)$ \\
1997 & 99 & 59 & 39 & $35(35.4)$ & $19(32.2)$ & $16(41.0)$ \\
1998 & 22 & 11 & 11 & $8(36.4)$ & $1(9.1)$ & $7(63.6)$ \\
$1999^{c}$ & 700 & 562 & 137 & $89(12.7)$ & $63(11.2)$ & $26(19.0)$ \\
2000 & 100 & 17 & 83 & $36(36.0)$ & $3(17.6)$ & $33(39.8)$ \\
Total & 2,080 & 1,510 & 533 & $352(16.9)$ & $200(13.2)$ & $150(27.1)$ \\
\hline
\end{tabular}

\footnotetext{
a Row totals for age classes may not sum to owl captures because age was undetermined for a small number of owls $(<1 \%)$

${ }^{\mathrm{b}}$ Recapture frequencies with percentage of owl captures that were recaptured that year in parentheses.

c Irruptive migration years.
} 
interpretation of body condition. Instead, body condition scores were calculated for individual owls using the index mass/wing chord ${ }^{1.462}$. The scaling exponent for this index was determined as the slope of the log-log plot of mass versus wing chord for all owls captured in this study (Fig. 1). That technique successfully eliminated any significant correlation between body-condition scores and wing chord ( $r=$ $-0.008, t=-0.35, P=0.72, n=2,048)$. Therefore, the resulting body-condition index is robust against structural size differences between groups of owls. Body-condition scores were standardized to units of standard deviations based on the mean body condition of all owls captured during nonirruptive years.

During two of the seven years of this study, capture rates were an order of magnitude higher than during the other five years (Table 1). To analyze annual patterns relative to the magnitude of the migration, the two large migration years were classified as irruptive years and the other five years were classified as nonirruptive years.

Numerous owls were recaptured during the same year. The proportion of owls recaptured was assumed to reflect probability of extended stopover by migrating owls. In addition, the duration of time between initial date of capture and date of final recapture was used as an estimate of minimum length of stopover for recaptured owls. That technique is conventionally used in banding studies of migratory stopover (e.g. Rappole and Warner 1976, Moore and Kerlinger 1987). Recapture events occurring on the same night as the initial capture for a given owl were excluded from all analyses.

Morphometric patterns were compared between irruptive and nonirruptive migration years using Student's $t$-tests. Chi-square tests were employed to compare age ratios among years and to compare recapture rates between age groups and years. Because length of stopover was not normally distributed, nonparametric Mann-Whitney $U$-tests were used to compare length of stopover between age groups and years, and Spearman rank order correlations were used to analyze relationships between age-specific stopover lengths and body condition scores. Incidence of recapture was recorded as a dichotomous dependent variable for each owl $(1=$ recaptured, 0 $=$ never recaptured) and logistic regression was used to estimate the probability of recapture as a function of body condition for specific age groups and migration years.

Results.-From 1994 to 2000, a total of 2,080 individual saw-whet owls were banded on the Eastern Shore of Virginia. Considerable variation occurred in number of owls captured each year (Table 1). Age ratio of saw-whet owls differed markedly depending on the magnitude of the migration $\left(\chi^{2}=387.0, \mathrm{df}=\right.$ $1, P<0.0001$; Table 1). Immature owls were in the minority during nonirruptive years, constituting
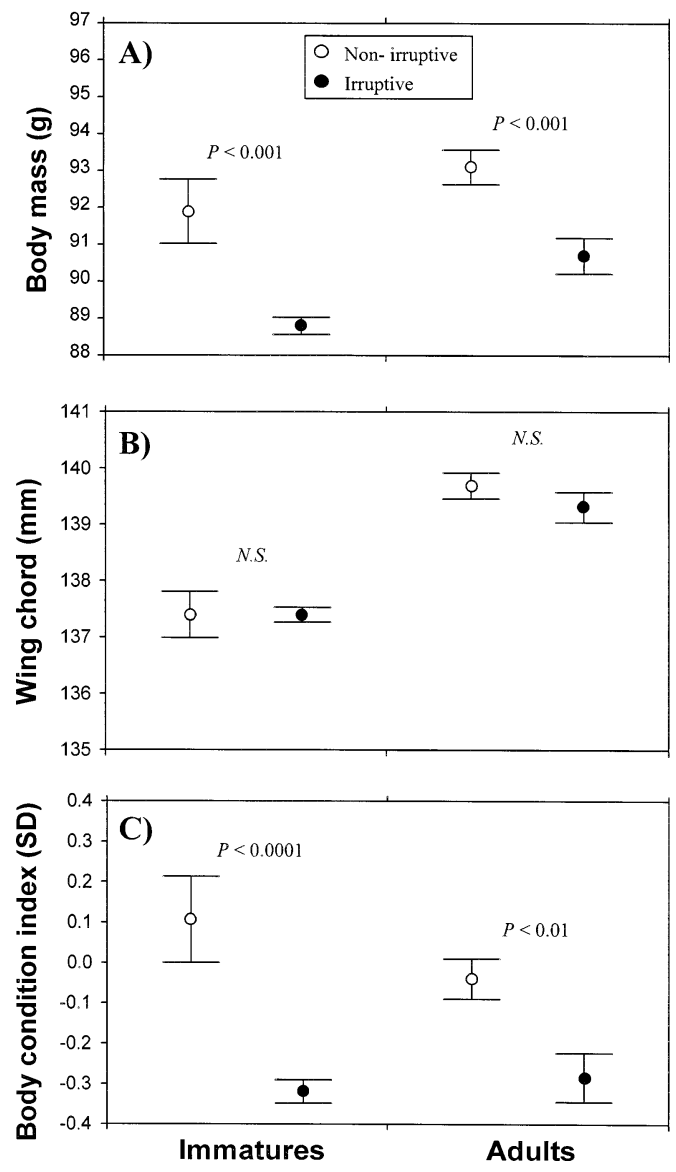

FIG. 2. (A) Body mass, (B) wing chord, and (C) body condition of immature and adult saw-whet owls captured during nonirruptive and irruptive migration years. Body condition (mass / wing chord ${ }^{1.462}$ ) was standardized to units of standard deviations based on the mean body condition of all owls captured during nonirruptive years. Points indicate means and whiskers show \pm 1 SE. $P$-values from pairwise $t$-tests are shown. NS indicates nonsignificant $(P>0.10)$.

only $33 \%$ of captures. Conversely, immature owls dominated irruptive migration events by constituting $82 \%$ of individual captures. During the two irruptive years combined, a total of 1,387 immature owls were captured compared to 299 adults. However, both age groups exhibited irruptive patterns of migration. Although capture rates of immature owls were more than $28 \times$ higher during irruptive years, capture rates of adults also increased three fold during irruptive years.

Morphometric patterns suggest that large migration events negatively affected body condition. Body masses of both immature and adult owls were sig- 


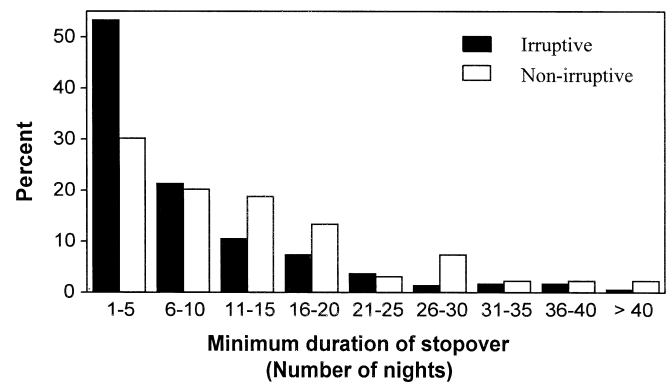

FIG. 3. Percentage distribution of minimum stopover lengths for all saw-whet owls recaptured during irruptive $(n=219)$ and non-irruptive $(n=97)$ migration years. Stopover lengths were aggregated into five night intervals.

nificantly lower during large migration years (immatures, $t=-3.73, \mathrm{df}=1,498, P<0.001$; adults, $t$ $=-3.43, \mathrm{df}=544, P<0.001$; Fig. 2A). Mean body mass of immature owls was $88.8 \pm$ SE of $0.23 \mathrm{~g}(n=$ $1,378)$ during irruptive years versus $91.9 \pm 0.87 \mathrm{~g}(n$ $=122$ ) during nonirruptive years, whereas mean body mass of adults was $90.8 \pm 0.48 \mathrm{~g}(n=295)$ during irruptive years versus $93.1 \pm 0.47 \mathrm{~g}(n=251)$ during non-irruptive years. However, age-specific wing chords were not significantly different between irruptive and nonirruptive migration years (immatures, $t=-0.04$, df $=1,506, P=0.96$; adults, $t=$ $-1.62, \mathrm{df}=549, P=0.11$; Fig. 2B). Body condition scores were lower for both immature and adult owls during irruptive years (immatures, $t=4.14$, $\mathrm{df}=$ $1,497, P<0.0001$; adults, $t=2.72, \mathrm{df}=542, P<0.01$; Fig. $2 \mathrm{C}$ ). Thus body mass differences apparently reflect poorer body condition during large migration events rather than structural body-size differences.

In addition to adverse effects on body condition, high owl densities may have affected stopover behavior of migrating owls. The proportion of owls recaptured during a given year was inversely related to the magnitude of the migration (Table 1). During each of the nonirruptive migration years, $31-40 \%$ of individual owls banded were subsequently recaptured during the same year. During the two irruptive migration years, however, $<13 \%$ of owls banded were recaptured. Thus, on an annual basis, there appeared to be an inverse density-dependent probability of recapture of migrating saw-whet owls.

Minimum length of stopover for recaptured owls was also inversely related to the magnitude of the migration. Length of stopover was significantly shorter during the two irruptive years than during the nonirruptive years (Mann-Whitney $U=10,176.5$, $z=-4.74, P<0.0001, n_{1}=219, n_{2}=133$; Fig. 3). Median duration of stopover was only 5 nights $(\bar{x}=$ $7.7 \pm 0.5$ nights) during irruptive years compared to 10 nights $(\bar{x}=12.7 \pm 0.9$ nights $)$ during nonirruptive years. During irruptive years, $53 \%(n=117)$ of stop-
A) Immature owls (irruptive years only).

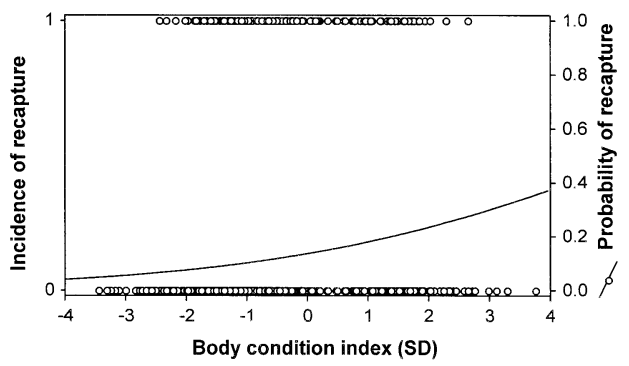

B) Adult owls (irruptive years only).

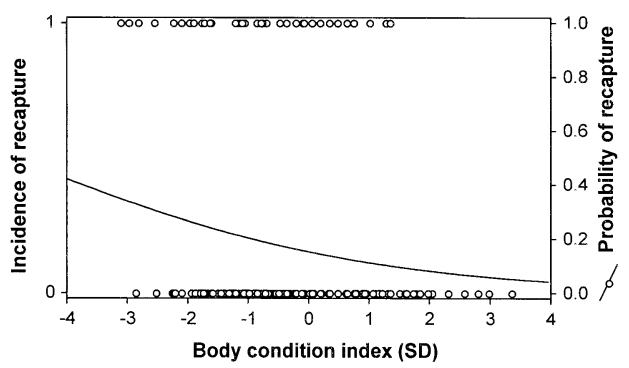

FIG. 4. Incidence of recapture and body condition of (A) immature and (B) adult saw-whet owls captured during irruptive migration years. " 1 " indicates an owl was recaptured, " 0 " indicates it was never recaptured. Body condition (mass/wing chord $^{1.462}$ ) was standardized to units of standard deviations based on the mean body condition of all owls captured during nonirruptive years. Curves estimate probability of recapture as a function of body condition based on logistic regression. Both regressions are statistically significant (immatures: $P<$ 0.001 , adults: $P<0.01$ ).

overs lasted for five nights or less. During nonirruptive years, $70 \%(n=93)$ of stopovers lasted for more than 5 nights and 50\% $(n=66)$ lasted for more than 10 nights.

Adult owls were more likely to be recaptured than immature owls during nonirruptive years but not during irruptive years. In the nonirruptive years, $42 \%(n=105)$ of adults were recaptured versus only $23 \%(n=28)$ of immature birds $\left(\chi^{2}=12.52, \mathrm{df}=1\right.$, $P<0.001)$. In the irruptive years, however, there was no significant difference in recapture probabilities between age groups $\left(\chi^{2}=1.93, \mathrm{df}=1, P=0.17\right)$ and only $15 \%(n=45)$ and $12 \%(n=172)$ of adult and immature owls were recaptured, respectively. Apparently when number of migrating owls was low, adults were more likely to stopover than immature owls. In large migration years, however, migrating owls saturated local habitats. High owl densities 
may have prevented a large percentage of owls from stopping over, regardless of their age class.

Although minimum stopover lengths were greater for adults than for immature owls $(U=12,549, z=$ -2.62, $P<0.01)$, that difference resulted from a large proportion of immature owls being captured during irruptive years when stopover lengths were markedly shorter. Stopover lengths did not vary between age groups within nonirruptive years $(U=$ $1,376.5, z=0.52, P=0.61$ ) nor within irruptive years $(U=4242.5, z=-0.74, P=0.46)$. The median duration of stopover was 10 nights for each age group during nonirruptive years and only 5 nights for each age group during irruptive years.

Logistic regression was used to test the relationship between probability of recapture and body condition for each age group during irruptive and nonirruptive years. Our results indicate that the probability of recapture declined with body condition for adults during irruptive years $\left(\chi^{2}=8.99\right.$, df $=1, P<0.01$; Fig. 4). Conversely, probability of recapture increased with body condition for immature owls during the same years $\left(\chi^{2}=7.50, \mathrm{df}=1, P<\right.$ 0.01; Fig. 4). Finally, body condition and probability of recapture were unrelated for both age classes during nonirruptive years (immatures, $\chi^{2}=0.13, \mathrm{df}=1$, $P=0.72$; adults, $\chi^{2}=0.45, \mathrm{df}=1, P=0.50$ ).

Minimum length of stopover for recaptured owls was related to initial body condition. During irruptive years, stopover lengths were negatively correlated with body condition of immature owls (Spear$\operatorname{man} R=-0.22, t=-2.91, P<0.01, n=172)$. For adult owls, the relationship was marginally nonsignificant; however, the sample size of recaptured adults was fairly small and the trend was consistent with immature owls $(R=-0.29, t=-1.96, P=0.06$, $n=43)$. During large migration years, individuals in good condition departed sooner than individuals in poor condition. During nonirruptive migration years, on the other hand, stopover lengths of adult owls were positively correlated with body condition $(R=0.30, t=3.18, P<0.01, n=105)$. This relationship was nonsignificant for immature owls $(R=$ $-0.17, t=-0.88, P=0.39, n=28$ ).

Discussion.-Intensive efforts to trap saw-whet owls with audiolures in recent years have demonstrated that the species is an irruptive migrant in the eastern United States. Previous researchers have suggested that annual variation in the number of sawwhet owls migrating is a function of the number of immature birds involved, and therefore depends on variation in breeding success (Weir et al. 1980). Although age ratios were heavily skewed toward immature birds during irruptive years, adults also migrated in irruptive fashion. Therefore, breeding success alone cannot explain the irruptive pattern of migration. The underlying cause of irruptive migration events by saw-whet owls remains to be determined. However, we suggest that density-dependent processes play an important role in causing owls to move.

Our data show that energetic condition was related to annual magnitude of the migration. During irruptive years, body masses and body-condition index scores were significantly lower for all owls, but particularly so for immature owls. Based on age-specific wing chord data, there was no evidence of any major differences in sex ratio or general structural body size among years. Instead, we suggest that increased competition for limited resources along the migration route had negative effects on body condition. Relationships between owl density, resource availability, and food-intake rates have not been directly tested for migratory owls. However, Moore and Yong (1991) demonstrated that migratory passerines depress resource abundance during stopover and that rates of energetic intake are negatively correlated with migrant density. Their results suggest that food-based competition among high concentrations of migrants negatively affects energetic condition. Likewise, reduced body condition of saw-whet owls may also result from density-dependent effects of competition during large migration events.

In addition to energetic condition, stopover patterns also depended on magnitude of the migration. During irruptive migration years, recapture rates were several times lower and, among owls that were recaptured, stopover lengths were about half as long. Access to food, habitat, or high-quality perch sites may be greatly reduced when number of migrating owls is very high. As a result, individuals may be more likely to forego stopover and continue migrating or to make shorter stays. Studies have demonstrated that migrant passerines do seem to track measures of habitat quality (Hutto 1985, Martin and Karr 1986). If local resource availability is low, migrating birds are more likely to move on in search of better stopover sites (Lindstrom and Alerstam 1986). We suggest that during irruptive migration years, high owl densities translate to low prey or habitat availability per owl, thus forcing owls to resume migrating sooner. Conversely, during nonirruptive years, recapture rates were very high and long stopover times were more common, suggesting that local habitats were more suitable for extended stopover when the number of migrants was low. Experienced adults in particular may be more likely to reside in a local area until migration becomes absolutely necessary.

Much of the literature on stopover ecology has dealt with the relationship between energetic condition and stopover patterns. Studies of passerines and shorebirds have demonstrated that birds in poor energetic condition (i.e. low body mass or fat content) usually tend to have higher probabilities of recapture (Morris et al. 1996), longer stopover times (Dunn et al. 1988), or both (Moore and Kerlinger 1987). Birds with depleted fuel reserves must stop 
longer to replenish energy supplies before continuing to migrate. However, in a study of migrating Bald Eagles (Haliaeetus leucocephalus), Restani (2000) found no relationship between body condition and stopover patterns. He proposed a hypothesis that only small-bodied species and birds that migrate by powered flight are likely to show stopover patterns that are sensitive to body condition. Indeed, the relationship between body condition and stopover in saw-whet owls, which are relatively small-bodied and use powered flapping flight, was consistent with results from studies of passerines and shorebirds, but only during irruptive migration years. During such years, we found negative correlations between body condition and stopover length of all owls and between condition and probability of recapture of adults. Owls may be minimizing length of stopover to the extent that energetic condition allows. Individuals that maintain good body condition tend to make very brief stopovers and adults in good condition may forego stopover altogether. Birds in poor condition, on the other hand, may have to stay longer, perhaps in an attempt to replenish energy supplies before continuing to migrate.

During nonirruptive years, however, only adult owls showed any significant relationship between body condition and stopover patterns. A positive relationship was found between body condition of adults and length of stopover. Individuals arriving on the Lower Delmarva Peninsula may be evaluating local areas for the potential of extended stopover. During light migration years, not only do a high percentage of adults elect to stopover, but among those that do, individuals in good condition make longer stopovers. Perhaps adults in good condition are better able to establish extended residency than owls in poor condition and immature owls.

Various factors are likely to contribute to migration patterns of saw-whet owls. Proximate cues such as weather and topographic features are likely to influence migration routes and timing (Weir et al. 1980). The role of those factors in irruptive migration and stopover patterns needs further study. However, among irruptive migrants in general, the ultimate factor believed to contribute to the magnitude of migration is temporal variation in consumer to resource ratios (Lack 1954, Newton 1972, Gauthreaux 1982). High consumer densities can exacerbate seasonal food shortages and force birds to migrate. Although data on prey availability along the migration route are not available, we suggest that resource availability per migrating owl is limited during years when the volume of migrants is very large. As a result, the energetic condition of owls is depressed and local habitats are much less suitable for long-term stopover. During such years, stopover patterns of sawwhet owls are consistent with conventional timeminimization strategies seen in many other species of migratory birds. Conversely, during years when migrant density is low, local conditions may be more conducive for extended stay, and therefore migration proceeds more casually.

Acknowledgments.-We thank S. Stairs, S. Rice, D. Schwab, S. Flickinger, and D. Summers for permitting access to the Eastern Shore of Virginia National Wildlife Refuge, Gatr Tract/Mockhorn Island Wildlife Management Area, and Kiptopeke State Park. This project was initiated after much needed advice and technical support from D. Brinker. Many individuals assisted with owl banding efforts including A. Beheler, D. Bradshaw, M. Byrd, J. Cameron, E. Hodnett, L. Hoffman, R. Lukei, B. Paxton, W. Sbrega, D. Schwab, R. Sipe, B. Sullivan, M. Watts, O. Whalen, and M. Wilson. Funding for this project was provided by the Center for Conservation Biology at the College of William and Mary, the Virginia Department of Game and Inland Fisheries, and the Virginia Department of Environmental Quality. R. Cannings and J. Marks provided helpful comments on an earlier version of this manuscript.

\section{Literature Cited}

Blem, C. R. 1980. The energetics of migration. Pages 175-224 in Animal Migration, Orientation, and Navigation (S. A. Gauthreaux, Ed.). Academic Press, New York.

Brinker, D. F., K. E. Duffy, D. M. Whalen, B. D. Watts, AND K. M. Dodge. 1997. Autumn migration of Northern Saw-whet Owls (Aegolius acadicus) in the Middle Atlantic and Northeastern United States: What observations from 1995 suggest. Pages 74-89 in Biology and Conservation of Owls of the Northern Hemisphere (J. R. Duncan, D. H. Johnson, and T. H. Nicholls, Eds.). U.S. Department of Agriculture, Forest Service General Technical Report NC-190.

CAnNings, R. J. 1993. Northern Saw-whet Owl (Aegolius acadicus). In The Birds of North America, no. 42 (A. Poole and F. Gill, Eds.). Academy of Natural Sciences, Philadelphia, and American Ornithologists' Union, Washington, D.C.

COHEN, D. 1967. Optimization of seasonal migratory behavior. American Naturalist 101:5-17.

DAvis, T. H. 1966. The 1965 Saw-whet Owl invasion. Kingbird 16:69-72.

Duffy, K., AND P. Kerlinger. 1992. Autumn owl migration at Cape May Point, New Jersey. Wilson Bulletin 104:312-320.

DunN, P. O., T. A. MAY, And M. A. McCollough. 1988. Length of stay and fat content of migrant Semipalmated Sandpipers in eastern Maine. Condor 90:824-835.

Evans, D. L., AND R. N. Rosenfield. 1987. Remigial molt in fall migrant Long-eared and Northern Saw-whet owls. Pages 209-214 in Biology and Conservation of Northern Forest Owls (R. W. Nero, R. J. Clark, R. J. Knapton, and R. H. Hamre, 
Eds.). U.S. Department of Agriculture, Forest Service General Technical Report RM-142.

Fretwell, S. D. 1972. Populations in a Seasonal Environment. Princeton University Press, Princeton, New Jersey.

Gauthreaux, S. A. 1982. The ecology and evolution of avian migration systems. Pages 93-168 in Avian Biology, vol. 6 (D. S. Farner, J. R. King, and K. C. Parkes, Eds.). Academic Press, New York.

Hedenstrom, A. 1993. Migration by soaring or flapping flight in birds: The relative importance of energy cost and speed. Philosophical Transactions of the Royal Society of London, Series B 342:353-361.

Hutto, R. L. 1985. Seasonal changes in the habitat distribution of transient insectivorous birds in Southeastern Arizona: Competition mediated? Auk 102:120-132.

LACK, D. 1954. The Natural Regulation of Animal Numbers. Oxford University Press, London.

LACK, D. 1968. Bird migration and natural selection. Oikos 19:1-9.

Lindstrom, A., AND T. Alerstam. 1986. The adaptive significance of reoriented migration of chaffinches Fringilla coelebs and Bramblings F. montifringilla during autumn in southern Sweden. Behavioral Ecology and Sociobiology 19:417424.

MARTIN, T. E., AND J. R. KARR. 1986. Patch utilization by migrating birds: Resource oriented? Ornis Scandinavica 17:165-174.

MoOre, F. R., AND P. KerLinger. 1987. Stopover and fat deposition by North American wood-warblers (Parulinae) following spring migration over the Gulf of Mexico. Oecologia 74:47-54.

MoOrE, F. R., AND W. YoNG. 1991. Evidence of foodbased competition among passerine migrants during stopover. Behavioral Ecology and Sociobiology 28:85-90.

Morris, S. R., D. W. Holmes, AND M. E. Richmond. 1996. A ten-year study of the stopover patterns of migratory passerines during fall migration on Appledore Island, Maine. Condor 98:395-409.

NAGY, K. A. 1987. Field metabolic rate and food requirement scaling in mammals and birds. Ecological Monographs 57:111-128.

Newton, I. 1972. Finches. Collins, London.

RAPPOLE, J. H., AND D. W. WARNER. 1976. Relationships between behavior, physiology and weather in avian transients at a migration stopover site. Oecologia 26:193-212.

Restani, M. 2000. Age-specific stopover behavior of migrant Bald Eagles. Wilson Bulletin 112:28-34.

Russell, R. W., P. Dunne, C. Sutton, And P. KerLINGER. 1991. A visual study of migrating owls at Cape May Point, New Jersey. Condor 93:5561.

Weir, R. D., F. COOKe, M. H. EdWARds, ANd R. B. STEWART. 1980. Fall migration of Saw-whet Owls at Prince Edward Point, Ontario. Wilson Bulletin 92:475-488.

Whalen, D. M., B. D. WATtS, AND D. W. Johnston. 2000. Diet of autumn migrating Northern Sawwhet Owls on the Eastern Shore of Virginia. Journal of Raptor Research 34:42-44.

Whalen, D. M., B. D. WATTS, M. D. Wilson, AND D. S. BRADSHAW. 1997. Magnitude and timing of the fall migration of Northern Saw-whet Owls through the eastern shore of Virginia, 19941996. Raven 68:97-104.

WoOdrey, M. S. 2000. Age-dependent aspects of stopover biology of passerine migrants. Studies in Avian Biology 20:43-52.

Received 27 March 2001, accepted 7 August 2002.

Associate Editor: C. Marti 